University of Michigan Law School

University of Michigan Law School Scholarship Repository

\title{
Statutes with Multiple Personality Disorders: The Value of Ambiguity in Statutory Design and Interpretation
}

\author{
Joseph A. Grundfest \\ Stanford Law School, grundfest@stanford.edu \\ Adam C. Pritchard \\ University of Michigan Law School, acplaw@umich.edu
}

Available at: https://repository.law.umich.edu/articles/1400

Follow this and additional works at: https://repository.law.umich.edu/articles

Part of the Courts Commons, Legislation Commons, and the Securities Law Commons

\section{Recommended Citation}

Pritchard, Adam C. "Statutes with Multiple Personality Disorders: The Value of Ambiguity in Statutory Design and Interpretation." J. A. Grundfest, co-author. Stan. L. Rev. 54, no. 4 (2002): 627-736.

This Article is brought to you for free and open access by the Faculty Scholarship at University of Michigan Law School Scholarship Repository. It has been accepted for inclusion in Articles by an authorized administrator of University of Michigan Law School Scholarship Repository. For more information, please contact mlaw.repository@umich.edu. 


\title{
ARTICLE
}

\section{Statutes with Multiple Personality Disorders: The Value of Ambiguity in Statutory Design and Interpretation}

\author{
Joseph A. Grundfest* \& A.C. Pritchard**
}

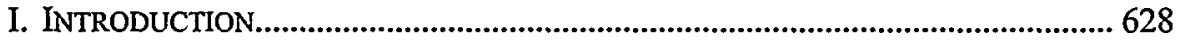

II. INTERPRETATION, AMBIGUTTY, AND EQUILIBRIUM…….....................................637

A. Ambiguity and Mixed Strategies............................................................ 637

B. Legislative Incentives for Ambiguity .....................................................640

C. Judicial Responses to Ambiguity: The Formalist Perspective.............. 642

D. Judicial Responses to Ambiguity: The Institutional Perspective......... 644

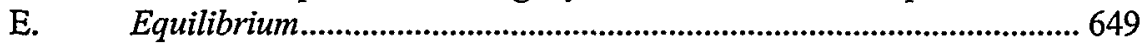

III. THE “STRONG INFERENCE” PLEADING STANDARD UNDER THE PSLRA.......... 650

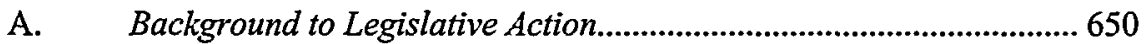

B. The Reform Act and the "Strong Inference" Standard........................ 652

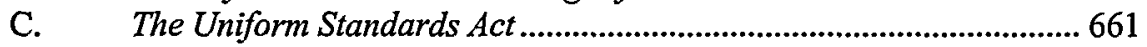

* William A. Franke Professor of Law and Business, Stanford Law School; Commissioner, United States Securities and Exchange Commission, 1985-1990.

** Assistant Professor of Law, University of Michigan Law School. Professor Pritchard was previously Senior Counsel at the Securities and Exchange Commission and in that capacity wrote the Commission's amicus briefs in two of the cases discussed in this Article: In re Silicon Graphics Inc. Sec. Litig., 183 F.3d 970 (9th Cir. 1999) and In re Comshare, Inc. Sec. Litig., 183 F.3d 542 (6th Cir. 1999). The views expressed here, however, are those of the authors alone and do not represent the views of the Commission or its staff.

The authors are grateful to Evan Caminker, Steven Choi, Hanoch Dagan, Jesse Fried, Tracey George, Rick Hills, Rick Lampert, Jane Schacter, Elliott Weiss, and participants at a Fawley Lunch at the University of Michigan Law School, a faculty workshop at the Stanford Law School, and the Judging Business conference at the University of Michigan Law School for comments on earlier drafts of this Article. Susan Ehr provided extraordinary assistance in constructing our District Court Database. Victoria Stodden and Charles Mathis, Ph.D. candidates in statistics at Stanford University, were instrumental in helping execute our statistical analyses and in constructing our Statistical Appendix, which can be found at http:/law.stanford.edu/lawreview/gp2001/. Eric Cielaszyk, Tim Foley, Susan French, Kurt Kauffman, Daniel Spies, and Jeff Wu provided additional invaluable research assistance. 


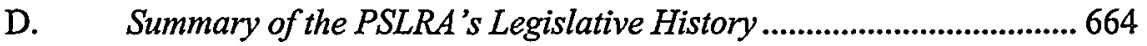

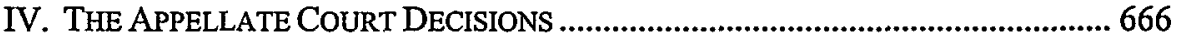

A. Summary of Appellate Court Decisions..............................................667

B. Inconsistent Appellate Interpretations................................................6 670

C. Political Patterns...............................................................................6 675

D. Patterns in the Decisions to Seek or Avoid Supreme Court Review... 676

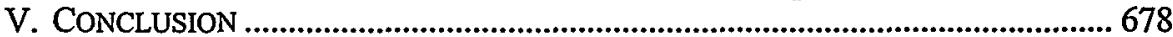

APPENDIX: STATISTICAL ANALYSIS OF DISTRICT COURT DECISIONS ..................... 684

A. The Sample, the Data, and the Hypotheses ........................................ 685

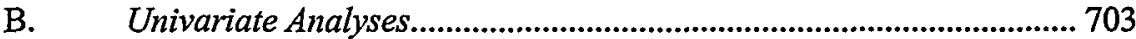

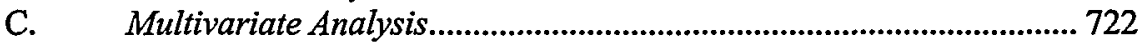

D. Discussion of Multivariate Results.................................................. 735

\section{INTRODUCTION}

Ambiguity serves a legislative purpose. When legislators perceive a need to compromise they can, among other strategies, "obscur[e] the particular meaning of a statute, allowing different legislators to read the obscured provisions the way they wish."1 Legislative ambiguity reaches its peak when a statute is so elegantly crafted that it credibly supports multiple inconsistent interpretations by legislators and judges. Legislators with opposing views can then claim that they have prevailed in the legislative arena, and, as long as courts continue to issue conflicting interpretations, these competing claims of legislative victory remain credible.

Formal legal doctrine, in contrast, frames legislative ambiguity as a problem to be solved rather than an opportunity to be exploited. Toward that end, judges and scholars have developed an arsenal of interpretive techniques that are designed to extract functional meaning from ambiguous statutory text and conflicting legislative history. The Supreme Court regularly addresses the question of statutory interpretation in its opinions and offers guidance as to

1. ABNer J. MiKva \& ERIC Lane, Legislative Process 779-80 (1997). Compromise can, no doubt, also be achieved through a variety of techniques that do not require legislative ambiguity, such as logrolling. Moreover, not all examples of legislative ambiguity are the consequence of a need to compromise. Ambiguity can, for example, arise as a result of inadvertence or change of circumstance. Our analysis recognizes these alternative techniques for achieving compromise and rationales for ambiguity, but focuses on instances in which ambiguity is clearly attributable to the legislative need to compromise. See infra Part II.

2. See, e.g., William N. Eskridge, Philip P. Frickey \& Elizabeth Garrett, LEGISLATION AND STATUTORY INTERPRETATION (2000); NORMAN J. SINGER, SUTHERLAND StatuTORY Construction (5th ed. 1992); Carlos E. Gonzalez, Reinterpretive Statutory Interpretation, 74 N.C. L. REV. 585 (1996). 
appropriate rules of construction. ${ }^{3}$ If these interpretive techniques are effective, then different judges faced with the challenge of construing a fixed piece of legislative text and history should produce consistent interpretations.

Legislators, staffers, and lobbyists are, however, well aware of the judiciary's interpretive technology. 4 If the judiciary can predictably ascribe a consistent meaning to a record that legislators intend to be ambiguous, then ambiguity's value as a tool of compromise is lost. Legislators therefore have an incentive to develop a technology of ambiguity that can frustrate the judiciary's most effective interpretive methods. 5

Judges are similarly aware of legislative techniques that are used to frustrate the judicial imputation of clear meaning. ${ }^{6}$ Judges can respond by strengthening their own interpretive technology in order to frustrate the legislature's efforts to obscure. ${ }^{7}$ Not all scholars are persuaded, however, that the judiciary is as committed to interpretive consistency as the formal canon suggests. ${ }^{\circ}$ A judicial preference for flexible standards of statutory interpretation over more rigid rules can, for example, be viewed as consistent with a preference for discretion. ${ }^{9}$ More broadly, judges who value the ability to exercise discretion would also rationally prefer ambiguous statutory language. ${ }^{10}$ Indeed, there is evidence that judges also practice conscious ambiguity as part of the art of judging when courts rely on vague language or avoid critical issues in order to craft decisions that maintain judicial

3. For a discussion of these principles, see infra Part III.

4. See, e.g., ANTONIN SCALIA, A MATTER OF INTERPRETATION 34 (1997) ("Nowadays, however, when it is universally known and expected that judges will resort to floor debates and (especially) committee reports as authoritative expressions of 'legislative intent,' affecting the courts rather than informing the Congress has become the primary purpose of the [legislative history] exercise.").

5. We recognize that it is meaningless to speak of congressional or judicial intent as though each branch had a single, coherent point of view when, in fact, each is composed of individuals with a wide range of often conflicting incentives. Instead, when we speak generally of legislative or judicial incentives, we mean only to suggest the existence of coalitions in each branch that have reason to behave in a manner consistent with the described tendency.

6. See, e.g., Scalia, supra note 4, wherein a Supreme Court Justice describes the techniques used by legislators to frustrate and influence judicial interpretation of statutory language.

7. See, e.g., Crosby v. Nat'l Foreign Trade Council, 530 U.S. 363, 388-91 (2000) (Scalia, J., concurring in the judgment). In his concurrence, Justice Scalia criticizes the majority opinion for even mentioning legislative history that supports the statutory language, and he reasons that such a citation is "harmful, since it tells future litigants that, even when a statute is clear on its face, and its effects clear upon the record, statements from the legislative history may help (and presumably harm) the case." Id. at 391.

8. See infra Part II.

9. "Standards authorize a judge to bring his intuitions of policy to bear on the decision of a case. Rules tell him not to." RICHARD A. POSNER, OVERCOMING LAW 134 (1995).

10. Id. 
coalitions. ${ }^{11}$ The Supreme Court's strongest proponent of precision in statutory construction, Justice Scalia, has gone so far as to observe that the high court has the ability to write an opinion "so that it says almost nothing," if that suits the Court's purpose. ${ }^{12}$

The legislative and judicial branches thus appear to be locked in an interpretive battle. The legislature has a clear incentive to value ambiguity because it facilitates compromise. The judiciary has crafted an array of interpretive rules designed to extract consistent meaning from intentionally ambiguous statutory utterances. There is debate, however, over the strength of the judiciary's incentive to apply rigorously its own interpretive technology. The result of this conflict between the branches is a rational expectations equilibrium in which each branch's strategy must take the other's into account. 13

Which force prevails? There is no theoretical reason to expect that the legislative ability to obscure will systematically defeat the judicial capacity to interpret, or vice versa. The question is essentially empirical. It is also historically and textually contingent. Accordingly, there may be periods during which, with respect to specific interpretive issues, one branch's technology more completely dominates the other, only to find the situation reversed during other periods. ${ }^{14}$

11. See, e.g., Cass R. Sunsten, One Case at A Time: Judicial Minimalism ON THE SUPREME COURT (2000).

12. Dahlia Lithwick, Shecky Scalia's Yuk Fest, SLATE, Feb. 28, 2001, at http://slate.msn.com/court/entries/01-02-28_101710.asp (describing oral argument before the United States Supreme Court in Good News Club v. Milford Central School District, 533 U.S. 98 (2001)). In Good News Club, Justice Scalia criticizes the decision below for creating ambiguity by failing to discuss a Supreme Court precedent that was squarely on point and that was fully briefed. Justice Scalia further observes that when it came time for the Supreme Court to draft its own decision in the matter, the Court retained the ability to write its opinion "so that it says almost nothing." $I d$.

13. By "rational expectations equilibrium" we mean only to suggest that an equilibrium solution to the battle between the legislative incentive to obscure and the judicial incentive to interpret must take into account the fact that each branch acts with full awareness of the strategic responses available to the other. We do not mean to specify any specific form of equilibrium, such as a Nash equilibrium. See generally Douglas G. BAIRD, ROBERT H. GerTner \& RANDAll C. Picker, Game TheORY AND THE LAW 23, $27-28$ (1994); Peter C. ORDESHOOK, GAME THEORY AND POLITICAL THEORY 118, 187 (1986); STEVEN M. SHEFFRIN, RATIONAL EXPECTATIONS (2d ed. 1996).

14. Consider, for example, the ambiguity that arises when Congress fails to specify whether a statute will support an implied private right of action. A change in the composition of the Supreme Court in the 1970s was correlated with the adoption of a new rule that prohibited the inference of a private right of action absent clear congressional intent to imply such a right. See Transamerica Mortgage Advisors, Inc. v. Lewis, 444 U.S. 11 (1979) (holding there is a limited private right of action under Investment Advisers Act to void an investment advisors contract, but implying no other private causes of action); Touche Ross \& Co. v. Redington, 442 U.S. 560 (1979) (holding there is no private cause of action under provision of Securities and Exchange Act requiring broker dealers to keep 
Testing whether the legislative ability to obscure trumps the judicial capacity to interpret is no easy matter. A rigorous test of this hypothesis requires the identification of a statute that was enacted as a result of a compromise rooted in willful rather than inadvertent legislative ambiguity. That statute's text and legislative history would then also ideally be subject to repeated judicial interpretations that are unconstrained by controlling precedent. If the courts were to coalesce quickly on a uniform interpretation of the statute then, on the facts of the statute presented, the judicial ability to interpret would prevail over the congressional capacity to obscure. On the other hand, if the courts were to disagree over the proper interpretation of the statutory language, and if their interpretations remained diffuse over time, the congressional capacity to obscure would prevail.

An appropriate sample for such analysis is unlikely to arise at the Supreme Court or circuit court level. Because the Supreme Court rarely has occasion to interpret the same statutory language more than once, any analysis of Supreme Court practice in statutory construction will fail to control for variations in text and legislative history across different statutes. This is, we believe, a significant constraint on the usefulness of Supreme Court decisions as a database for the analysis of interpretive technology. No doubt, a Supreme Court decision interpreting an ambiguous statute constitutes a final decision on the question presented. ${ }^{15}$ The finality of such a decision does not, however, imply that the judicial ability to interpret has trumped the legislative capacity to obscure. The legislature and judiciary are involved in a repeat game process; i.e., the Supreme Court must interpret many ambiguous statutes over time. The legislative capacity to obscure can prevail in this larger "super-game," even if it is preordained to fail when the Supreme Court interprets individual statutes, as long as the Supreme Court's ultimate decisions are random over a series of

records and file reports with Securities and Exchange Commission); Cort v. Ash, 422 U.S. 66 (1975) (holding there is no private cause of action under 18 U.S.C. $\$ 610$ ). But see Cannon v. Univ. of Chi., 441 U.S. 677 (1979) (recognizing private cause of action under Title IX even though none is expressly defined). See generally Joseph A. Grundfest, Disimplying Private Rights of Action Under the Federal Securities Laws: The Commission's Authority, 107 HARV. L. REV. 961, 992-96 (1994). The consequence was to make it more difficult for legislators to argue that ambiguity expressed in the form of silence could later support the imputation of a private right of action. This shift by the high court temporarily tilted the balance of power on this one interpretive issue away from the congressional ability to obscure and toward the judicial capacity to interpret with precision. No doubt, ambiguity on this question is reintroduced over time as the legislature learns to generate conflicting signals as to whether it "intends" to imply a private right of action, but this evolutionary process only underscores the contingent nature of the question posed.

15. The decision may, however, create a new set of ambiguities that lead to another round of litigation or to legislation designed to undo the Court's interpretation. See, e.g., William N. Eskridge, Jr., Overriding Supreme Court Statutory Interpretation Decisions, 101 YALE L.J.331 (1991). 
independent statutory interpretations. ${ }^{16}$ The contours of a splintered opinion in an individual Supreme Court case can also provide insight into the legislature's ability to frustrate the Court's interpretive technology. ${ }^{17}$ A five-four split more strongly supports a legislative ability to obscure than a unanimous interpretation, but such information is at best suggestive.

Circuit court decisions are a better source of insight regarding Congress' ability to obscure. When circuits split over the interpretation of identical statutory text and legislative history, the simple existence of the split suggests that Congress has introduced some level of ambiguity into the interpretation of the statute at issue. The number of circuits that split, the number of differing interpretations that arise, and the contours of the circuit splits provide additional useful information about the congressional ability to obscure. The small number of circuits and rules of intra-circuit stare decisis suggest, however, that appellate decisions will also be too few to support formal statistical analysis.

A sample sufficiently large to permit formal statistical analysis of the legislative ability to obscure as pitted against the judicial capacity to interpret is thus likely to arise only if district courts have an opportunity to write a sufficiently large number of opinions interpreting a single ambiguous text before the circuit courts or the Supreme Court issue controlling precedent. District courts are generally the first (and sometimes the last) tribunals to interpret a particular federal statute. Their interpretations often represent the "law" of a statute for the first few years after a statute's enactment. If a sufficiently large number of unconstrained district court interpretations of a fixed statutory and legislative history can be gathered, then such a sample could support formal statistical analyses that pit the judicial ability to interpret against the legislative capacity to obscure. Such a sample could also provide insight into whether, for a particular statute, the resolution of statutory ambiguity has a material predictive effect on the disposition of cases. The sample could also allow for tests of various "legal realist" hypotheses. These tests could determine whether the patterns in individual judges' approaches to legislative ambiguity can be explained by an array of exogenous factors, such as a desire

16. Because participants in the legislative and judicial process repeatedly bargain with each other over time they are able to trade off favorable results in one situation for unfavorable results in another. Ambiguity can thus be defined in the "small," in the sense that a specific statute is interpreted inconsistently, or in the "large," in the sense that individual statutes may be interpreted consistently but that different statutes are interpreted differently over time. The latter strategy is consistent with a logrolling or vote-trading equilibrium over time. See ORDESHOOK, supra note 13, at 56, 89-94. For a discussion of the importance of repeat games, or "super-games," in the legal process, see BAIRD ET AL., supra note 13, at 15-18, and KeITH KREHBIEL, PIVOTAL POLITICS: A THEORY OF U.S. LAWMAKING (1998).

17. See, e.g., Joseph A. Grundfest, We Must Never Forget It Is an Inkblot We Are Expounding: Section 10(b) as Rorschach Test, 29 LoY. L.A. L. REv. 41 (1995). 
to control judicial docket loads, the characteristics of litigants in an individual proceeding, or the political affiliations and pre-confirmation experiences of the individual judges interpreting the ambiguous legislative record.

We believe that the "strong inference" provision of the Private Securities Litigation Reform Act of 1995 ("PSLRA" or "Reform Act") 18 satisfies the requirements necessary for a formal statistical analysis of the sort just described. In an attempt to discourage meritless securities fraud litigation, the PSLRA requires that private plaintiffs, in addition to satisfying the specificity requirements of Federal Rule of Civil Procedure 9(b), "state with particularity facts giving rise to a strong inference that the defendant acted with the requisite state of mind." 19 The interpretation of this "strong inference" pleading requirement has become one of the most contested issues in federal securities law.20

As explained below, the "strong inference" provision can be viewed either as clear on its face or as subject to significant uncertainty. The legislative history leading to the enactment of the "strong inference" provision is also exquisitely conflicted as key actors in the legislative process, representing diametrically opposed interest groups, articulated inconsistent interpretations of the standard. The record further supports the conclusion that the PSLRA would not have been enacted but for a conscious agreement to disagree over the proper interpretation of the "strong inference" provision. The net result of these competing efforts was a statute and legislative history designed to frustrate doctrines of judicial interpretation as a price of enactment.

But did the competing congressional constituencies succeed in their efforts to obscure the statute's meaning? We have identified thirty-three appellate decisions interpreting and applying the "strong inference" standard. We have also identified 167 district court decisions that were rendered prior to the issuance of controlling appellate precedent, each of which interprets the same "strong inference" standard. Each of the judges in this sample faced the same mix of text and legislative history. Each confronted the challenge of using a common set of interpretive tools to impute meaning to a common legislative record. The structure of this sample thus distinguishes our study from previous empirical analyses of statutory interpretation that fail to hold constant the text and history subject to analysis. ${ }^{21}$

18. Pub. L. No. 104-67, 109 Stat. 737 (1995) (codified as amended in scattered sections of 15 U.S.C.).

19. 15 U.S.C. $\$ 78 \mathrm{u}-4(\mathrm{~b})(2)$ (emphasis added).

20. See, e.g., Jordan Eth \& Daniel S. Drosman, The Private Securities Litigation Reform Act: Five Years Young, 34 SEC. \& COMMOD. REG. REP. 153, 160-61 (2001).

21. The closest analogue we are aware of is Gregory C. Sisk, Michael Heise \& Andrew P. Morriss, Charting the Influences on the Judicial Mind: An Empirical Study of Judicial Reasoning, 73 N.Y.U. L. REV. 1377 (1998). This study differs from ours, however, in that it examines a question of constitutional interpretation-the constitutionality of the Sentencing 
This Article proceeds in four parts, and is accompanied by an appendix. Part II frames the legislative and interpretive process as a series of games. It analyzes legislators' motivations for the use of ambiguity and describes legislative means for creating ambiguity. Part II also describes the judiciary's interpretive technology, and explores incentives that the courts may have to acquiesce in legislative ambiguity. Part III traces the legislative history of the PSLRA's "strong inference" provision, explaining how competing factions in Congress introduced multiple conflicting interpretations of the "strong inference" standard, and why such ambiguity was necessary for the statute's enactment.

Part IV analyzes thirty-three appellate court decisions interpreting the "strong inference" standard. We find that the circuits are split into three distinct interpretive camps. We also find that panels within the same circuit have adopted conflicting interpretations of identical language, that the courts often differ in the application of the identical standard to a common set of facts, and that a new split has emerged as to whether the "strong inference" provision applies in resolving motions for summary judgment as well as motions to dismiss. We conclude that, on these facts, the congressional ability to obscure prevails over the judiciary's ability to interpret at the appellate level.

The Appendix to this Article reports on an empirical analysis of 167 decisions by district courts resolving motions to dismiss on the basis of the "strong inference" standard. We find that a large number of judges practice a strategy of judicial minimalism by ruling on motions to dismiss without interpreting the statutory language. They conclude that the complaints at issue are either so well crafted that they satisfy the strongest interpretation of the standard or so poorly drafted that they fail the weakest interpretation, without ever defining the standard. Among judges who address the question, behavior in the aggregate is consistent with a coin-toss model of decision-making in which judges first toss a fair coin to determine whether the "strong inference" standard incorporates the Second Circuit standard, the weakest interpretation of the heightened pleading standard, or requires a stricter interpretation. If the coin lands heads, the judge adopts the Second Circuit standard. If the coin lands tails, the judge tosses it again to decide between an intermediate standard and the strictest of the three standards, the Silicon Graphics standard. The district court data thus reinforce the conclusion that the legislative capacity to obscure has here defeated the judicial capacity to interpret.

The Appendix also reports on statistical tests of a wide variety of "legal realist" hypotheses that search for patterns in judicial behavior that might explain the selection of an interpretive standard or the resolution of the

Guidelines-rather than a question of statutory interpretation. It therefore does not implicate the relationship between Congress and the courts because the judges in that study are constrained primarily by prior judicial precedent, not by text and legislative history. 
underlying motion to dismiss. The dominant conclusion of this analysis is that the data must be interpreted with great caution. The significance of individual explanatory variables is highly contingent on the specification of the underlying model and on the regression technique employed. There is, however, no a priori theory that supports any one model specification or statistical approach over any other. We therefore test a large number of model specifications and apply a range of statistical techniques in a search for patterns in the data. This approach opens us to the legitimate criticism that we have engaged in a form of "data mining." We respond by observing that our online statistical appendix reports all regression results, even those that are statistically insignificant, and that we consider relationships to be analytically meaningful only if they are statistically significant across a large number of alternative specifications. We also observe that this approach is preferable to one that focuses solely on specifications and techniques that generate the largest number of statistically significant relationships because such an approach is likely to exaggerate the true incidence of statistically significant relationships, particularly given the absence of an underlying theory that could be used to impose structure on any of the statistical models.

With this cautionary language firmly in mind, our multivariate analysis appears to support the conclusion that, when it comes to selecting an interpretive standard, judges who sit in busier districts (measured in terms of docket load per judge) and judges who sit in districts that hear more cases involving high-technology issuers (measured in terms of the number of decisions involving high-technology issuers per judge sitting in that district) tend to adopt pro-defendant interpretations of the "strong inference" standard. These observations are consistent with a "docket control" hypothesis (judges adopt stricter standards in order to make it easier to dismiss cases and thereby clear their dockets more quickly) and with a "technology is different" hypothesis (complaints filed against high-technology issuers are, all other factors being equal, weaker than complaints filed against other issuers). We also find that judges appointed by Presidents Carter, Ford, and Nixon tend to adopt pro-plaintiff interpretations of the "strong inference" standard. This latter observation is inconsistent with a pure Democrat-Republican dichotimization of the bench. It instead suggests that, to the extent political factors correlate with judicial decisionmaking, it may be necessary to adopt a more refined description of the judicial process.

With respect to the resolution of the underlying motions to dismiss, the multivariate data again suggest that district court judges who sit in busier districts, and in districts that hear more cases involving high-technology defendants, tend to issue pro-defendant rulings on motions to dismiss. The analysis also suggests that judges who have ruled on multiple cases in our database are even more strongly inclined to issue pro-defendant rulings on motions to dismiss. This finding is consistent with the observation that, in the 
world of class action securities fraud litigation, familiarity breeds skepticism on the bench. The data also suggest that the definition of the pleading standard helps explain the outcome of the motion to dismiss, but that other variables can be more significant than the precise specification of the pleading standard in explaining the resolution of the underlying motion. This finding is consistent with the observation from the appellate data that there is substantial plasticity in the application of the "strong inference" standard to a given set of facts, but that stricter interpretations of the standard are nonetheless correlated with a more frequent incidence of pro-defendant rulings.

Part V concludes with the observation that, on the text and legislative history of the "strong inference" provision, the congressional ability to obscure thrashes the judicial capacity to interpret. Although we must be cautious in generalizing from a study that examines the interpretation of two words in a single statute, the thoroughness with which Congress is able to flummox the courts suggests a much broader observation. It is entirely rational that, in the repeat game between Congress and the courts, both branches prefer a degree of ambiguity that can sustain mixed-strategy equilibria.22 It follows that efforts to articulate more consistent and precise rules for statutory construction could be doomed to failure whether those rules are described as textualist, intentionalist, expressive, dynamic, or of any other form. Those rules could be doomed to fail in practice not because they are illogical or incorrect in any sense, but because they seek to impose a degree of uniformity in interpretation that is inconsistent with the equilibrium relationship between the legislative and judicial branches. Put another way, an unresolvable measure of ambiguity may be part of the essential fabric of our legal regime. Efforts to impose greater precision than the underlying political structure can bear may lead nowhere because the political equilibrium between the judicial and legislative branches may benefit from a base level of interpretive ambiguity.

Thus, even if the courts could invent a magic black box that processed statutory text and legislative history to produce a precise and predictable formula for the interpretation of any legislative language, there would be good institutional reasons for Congress not to want the courts to use that black box. There also would be good reasons for the courts not to want to use it. Ambiguity, we think, may have strong survival characteristics in our multibranch legal regime that relies on political compromise within and among the branches in order to function.

22. A "mixed strategy" is one in which the players react randomly according to a formula designed to optimize their objectives over time. See, e.g., BAIRD ET AL., supra note 13 , at 37-39, 42-43; ORDESHOOK, supra note 13, at 133, 136-37, 182. 


\section{INTERPRETATION, AMBIGUITY, AND EQUILIBRIUM}

The concept of "bargaining in the shadow of the law" is now a staple of legal analysis. ${ }^{23}$ We suggest that the crafting and interpretation of statutory language involve a simultaneous bargain in which the legislative and judicial branches negotiate in each other's shadow.

\section{A. Ambiguity and Mixed Strategies}

The process of statutory design and interpretation can be modeled as involving three "games." First is a "legislative game" in which a legislature develops a coalition sufficiently large to support passage of a bill over the threat of any credible veto. Second is a "judicial game" in which courts engage in the act of judging, and thereby interpret the statute enacted by the legislature. Third is an "interactive-interpretive game" between the legislative and judicial branches over the interpretation of statutory language and legislative history.

The notion that legislators are involved in a repeat process game when they enact statutes has been extensively explored in the literature. ${ }^{24}$ Legislators trade votes, manipulate agendas, stack committees and subcommittees, and participate in procedural ploys-all to achieve their legislative objectives. ${ }^{25}$

The notion that judges are also involved in a "game" when they decide cases has been expounded by Judge Richard Posner, but has received far less attention. ${ }^{26}$ Posner suggests that the act of judging can be described as a game in which judges seek to maximize a judicial utility function subject to the condition that their expression of "policy preferences and personal convictions"27 comports with the rules of judicial process. Posner distinguishes the "rules of judging" from the "rules of substantive law, to which the community is subject but to which judges in their judicial capacity relate differently, as law givers and law appliers." 28 He describes the rules of the judging game as being "institutional" and recognizes that different judges may have differing conceptions of those rules. Thus, "[s]ome judges play by 'activist' rules, others (a larger number) by rules of 'restraint' because those rules are more congenial to the legal profession's self image." 29 These rules

23. Robert Mnookin \& Lewis Kornhauser, Bargaining in the Shadow of the Law: The Case of Divorce, 88 YALE L.J. 950 (1979).

24. See, e.g., KEITH KREHBIEL, INFORMATION AND LEGISLATIVE ORGANIZATION (1991); KREHBIEL, supra note 16; ORDESHOOK, supra note 13.

25. See, e.g., KREHBIEL, INFORMAATION AND LEGISLATIVE ORGANIZATION.

26. POSNER, supra note 9 , at 109-44.

27. Id. at 31 .

28. Id. at 133 .

29. Id. 
are also often "uncertain or contested," 30 and can be driven by processes of professionalization and socialization and by a desire not to be reversed on appeal. 31 Indeed, it is only "because judges play by the rules of the judicial game"32 that their behavior can be predicted, thereby allowing "legislatures [to] control judicial behavior, though not perfectly, by substituting rules ... for standards." 33 Posner further observes that "[b]ecause obedience to the rules laid down by the legislature is itself a rule of the judicial game, a legislature can expect a fair degree of compliance by the judges with its rules even though there is no sanction for noncompliance." 34

The observations that legislators are aware of the rules by which judges play the judicial game and that legislators rely on those rules as part of the legislative process presage the third game: the game between the legislature and the courts over the proper interpretation of statutory language. While a growing literature models the relationship between Congress and the courts, ${ }^{35}$ no scholarship appears to focus on the role of statutory ambiguity in that relationship.

Broadly speaking, the equilibrium solution to any game can be described as involving either "pure" or "mixed" strategies. 36 A participant adopting a pure strategy follows a precisely defined decision rule: If another player does $x$ the response is $y$. A player adopting a mixed strategy follows a probabilistic rule: If another player does $x$ then the response is $y$ with a probability of $p_{y}, z$ with a probability of $p_{z}$, and so on. These mixed strategies are often analogized to a rule that tells a player "what dice to throw in order to choose an action."37 Players who are able to follow mixed strategies will always be able to find equilibria that are no worse than those available to players who are constrained to follow pure strategies. Mixed-strategy players may also be able to find

30. Id. at 129.

31. Id. at $128-36$.

32. Id. at 134.

33. Id.

34. Id.

35. See, e.g., Rafael Gely \& Pablo T. Spiller, A Rational Choice Theory of Supreme Court Statutory Decision with Applications to the State Farm and Grove City Cases, 6 J.L. ECON. \& ORG. 263 (1990); Jack Knight \& Lee Epstein, On the Struggle for Judicial Supremacy, 30 LAw \& Soc'y REv. 87 (1996); Andrew D. Martin, Congressional Decision Making and the Separation of Powers, 95 AM. PoL. SCI. REv. 361 (2001); McNollgast, Politics and the Courts: A Positive Theory of Judicial Doctrine and the Rule of Law, $68 \mathrm{~S}$. CAL. L. REv. 1631 (1995); James Rogers, Information and Judicial Review: A Signaling Game of Legislative-Judicial Interaction, 45 AM. J. POL. SCI. 84 (2001); Jeffrey Segal, Separation-of-Powers Games in the Positive Theory of Congress and Courts, 91 AM. POL. SCI. REV. 28 (1997).

36. See, e.g., Drew Fundenberg \& JeAn Tirole, Game TheORy 5 (1991) (describing a mixed strategy as a "probability distribution over pure strategies"); ERIC RASMUSSEN, GAMES \& INFORMATION: AN INTRODUCTION TO GAME THEORY 66-67 (3d ed. 2001).

37. RASMUSSEN, supra note 36 , at 67. 
equilibria in games that have no equilibrium if players are constrained to follow pure strategies.

The distinction between pure and mixed strategies has direct application to the process of statutory design and interpretation. If Congress seeks to adopt a statute that will be interpreted by the courts as a rule providing precise direction, then Congress must apply techniques that generate a pure strategy in the interactive-interpretive game between the judiciary and the legislature. Put another way, in order for the judiciary to apply a statute uniformly, Congress and the courts must both agree to follow a pure strategy: If Congress says $x$ then the courts will do $y$. This pure strategy can exist only if rules of statutory construction in the judicial game are sufficiently well defined by the Supreme Court that the legislature can predict with adequate certainty how a rule-based statute will be applied by the courts.

In contrast, if Congress decides that it must compromise and employ ambiguous, standards-based language in order to enact a piece of legislation, then the courts must agree to interpret the statute ambiguously in order for Congress to achieve its desired result. In that event, the equilibrium is a mixed strategy: If Congress says $x$ then the courts might do $y$ with a probability $p_{y}$, or $z$ with a probability $p_{z}$, etc. The observation of inconsistent judicial interpretations of the statutory language would then be viewed as the successful implementation of a mixed strategy that reflects an ambiguity born of compromise rather than the failure of the judiciary's interpretive technology. To be sure, the probabilities and ranges of actions associated with such mixed strategies need not be entirely random from the legislative or judicial perspective. By modulating the legislative text and history, the legislature can, given the prevailing rules of statutory construction, constrain the range of choices that the judiciary is likely to express as part of its mixed strategy and thereby influence the frequency with which a specific interpretation is likely to be adopted by the courts.

We are thereby able to formalize the notion of statutory ambiguity. Statutes that are rules-based, precise, and unambiguous are expressed as pure strategies in the interactive-interpretive equilibrium between legislatures and courts. Once enacted, these statutes should give rise to consistent judicial interpretation. Statutes that are standards-based and adopted as a consequence of a compromise rooted in ambiguity are expressed as mixed equilibria. Once enacted, these statutes should give rise to a range of potentially inconsistent interpretations that reflect the ambiguity intended by the legislative bargain. Significantly, a credible mixed-game strategy is possible for the legislature only if the judiciary does not have a technology of interpretation so effective that it can ascribe a consistent, precise meaning to even ambiguous statutory text. The existence and implementation of such a strategy by the judiciary would render legislative compromise through ambiguity impossible.

The technology of statutory construction is thus central to the structure of 
equilibrium in the game between Congress and the courts. This conceptualization of the legislative and interpretive process calls for greater exploration of the incentives for precision and ambiguity among legislators and judges alike.

\section{B. Legislative Incentives for Ambiguity}

Within the boundaries set by the Constitution, and subject to the veto power of the Executive, Congress can dictate any policy outcome it desires. When a statute's text is clear, its plain language is supposed to control its interpretation. ${ }^{38}$ It is a familiar story, however, that Congress sometimes does not provide a clear answer in the text of the statute to questions that courts must answer in order to resolve disputes.

There are several entirely innocent and socially responsible rationales for certain forms of legislative ambiguity. At one extreme, Congress might not even recognize that it is creating ambiguity. It might also fail to legislate with precision because it wishes to avoid cluttering the statutory text with excessive detail. Apart from aesthetic concerns, Congress may lack the foresight and expertise needed to specify every last jot and tittle of a rule in the text of the statute, and it could be inefficient for a legislature even to try. 39 Congress could also rationally decide that a legislative scheme will work better if discretion is delegated to the courts to resolve disputes according to flexible standards, even though the resulting flexibility generates foreseeable inconsistency in application. Legislating through standards may require ambiguity in the legislative language to confer that flexibility ${ }^{40}$ Ambiguity can also arise over time as a consequence of unforeseen technological, economic, or social developments. Ambiguity can, however, also be the result

38. See, e.g., Conn. Nat'l Bank v. Germain, 503 U.S. 249, 253-54 (1992) ("[I]n interpreting a statute a court should always turn first to one, cardinal canon before all others. We have stated time and again that courts must presume that a legislature says in a statute what it means and means in a statute what it says there.").

39. See Edward S. Adams \& Daniel A. Farber, Beyond the Formalism Debate: Expert Reasoning, Fuzzy Logic, and Complex Statutes, 52 VAND. L. Rev. 1243, 1314 (1999) ("It is tempting to say that one should try to make all rules as explicit as possible, in order to maximize the stability, predictability, and democratic accountability of the legal system. In reality, explicitness is like other human goods: it is valuable, but costly to produce and suffers from diminishing returns.").

40. There are limits to the flexibility that Congress can confer in a statute; an excessively ambiguous statute might violate the nondelegation doctrine. See David M. Driesen, Loose Canons and the "New" Nondelegation Doctrine (Apr. 19, 2001) ("If a statute itself does not properly delegate the needed authority to the judiciary, because it lacks an intelligible principle, then the statute's existence may not justify judicial construction. A lack of an intelligible principle might suggest that there is 'no law to apply' in resolving a case."), at Working Paper Series 53, http://papers.ssm.com/sol3/papers.cfm?abstract_ id $=267351$. 
of a need to compromise in order to accumulate a majority (or a veto-proof supermajority) in support of legislative action.

Indeed, it is not unusual for competing factions of Congress to "agree to disagree" in the drafting of a statute. ${ }^{41}$ Congress is made up of 535 individuals who represent divergent interests. When faced with a conflict among competing legislative coalitions, carefully crafted ambiguous language can allow legislators with divergent interests to adopt competing, inconsistent interpretations of the same statutory text. Legislators can point to the statutory text and legislative history that supports their favored interpretation, even though contradictory interpretations are equally plausible. In that event, the statute will develop "multiple personalities" as competing constituencies cite the same enactment in support of fundamentally irreconcilable positions. Each constituency can hope that its position will ultimately prevail, and ambiguity thereby expands the circle of winners in legislative battles, at least temporarily.

If Congress succeeds in creating such ambiguity, then determining which position will ultimately prevail is deferred until the Supreme Court decides the question, assuming that the Court even agrees to hear the question-an increasingly tenuous assumption given the growth in legislative output and the limited size of the Supreme Court's docket. Once the Supreme Court adjudicates the matter, the contours of the debate may change dramatically, but the dispute is not necessarily resolved. The Supreme Court's decision can itself generate a new range of ambiguities for the lower courts to resolve. The Supreme Court's decision can also provoke a new round of legislative activity designed to undo or modify the Court's decision. ${ }^{42}$ Supreme Court review thus poses a natural limit, though not always a hard stop, to Congress' ability to endow a statute with multiple competing personalities. By the time the Court decides, however, individual legislators may have left Congress, putting them beyond the wrath of disappointed supporters. Alternatively, legislators on the losing side may be able to blame the Court's willfulness for their constituency's defeat, and perhaps solicit additional contributions from the losing constituency to overturn the Court's decision with a new statute. Ambiguity thus allows legislators to claim short-term victory, and to shift accountability for a potential eventual defeat to the courts. ${ }^{43}$ Interest groups may not be taken in by such

41. See AbNer J. MikVa \& ERIC LANe, AN Introduction to Statutory INTERPRETATION AND THE LEGISLATIVE PROCESS 2 (1997) ("Some compromises result in a proposed provision being omitted from a statute, some result in changes in existing language, some result in additional (sometimes redundant, sometimes conflicting) language or provisions, and some result in clear statutory language purposely being made unclear.").

42. See, e.g., Eskridge, supra note 15.

43. See William N. Eskridge, Jr., Politics Without Romance: Implications of Public Choice Theory for Statutory Interpretation, 74 VA. L. REV. 275, 288 (1988) ("[W]hen a legislator cannot avoid conflictual demand patterns, she will try to satisfy all the relevant interest groups through a compromise statute acceptable to all concerned. If this cannot be accomplished, the legislator's next-best strategy will be to support an ambiguous law, with 
rationalizations, but they may reasonably prefer the compromise inherent in ambiguous language over the potential for defeat that could occur if they pressed for a more favorable but precise locution. The compromise facilitated by statutory ambiguity can thus represent an essential legislative device for reconciling conflicting policy positions.

\section{Judicial Responses to Ambiguity: The Formalist Perspective}

Formal legal analysis views ambiguity as a problem to be solved, not as an opportunity to be exploited. The Supreme Court has instructed lower courts to begin their analysis with the "plain language" of a statute. According to the Court's doctrine, that is also where the inquiry should end if the "plain language" is clear. Courts "may resort to a review of congressional intent or legislative history only when the language of the statute is not clear. ${ }^{2 / 4}$ But if Congress is bent on creating ambiguity, it can seek to craft language that is neither "plain" nor "clear." Moreover, a meaning that is plain to one judge may be obscure to another.

In the absence of "plain" or "clear" meaning, courts resort to legislative history. 45 This reliance on legislative history has come under attack in recent

details to be filled in later by courts or agencies. In that way, the legislator will be able to assure each group that it won, and then will be able to blame a court or agency if subsequent developments belie that assurance.").

44. In re Comshare, Inc. Sec. Litig., 183 F.3d 542, 549 (6th Cir. 1999) (citing Consumer Prod. Safety Comm'n v. GTE Sylvania, Inc., 447 U.S. 102, 108 (1980)).

45. Empirical studies of judicial reliance on legislative history have focused primarily on the Supreme Court. See Jorge L. Carro \& Andrew R. Brann, The U.S. Supreme Court and the Use of Legislative Histories: A Statistical Analysis, 22 JURIMETRICS J. 294 (1982); Thomas W. Merrill, Textualism and the Future of the Chevron Doctrine, 72 WASH. U. L.Q. 351 (1994); Randall W. Quinn, The Supreme Court's Use of Legislative History in Interpreting the Federal Securities Laws, 22 SEC. REG. L.J. 262 (1994); Jane S. Schacter, The Confounding Common Law Originalism in Recent Supreme Court Statutory Interpretation: Implications for the Legislative History Debate and Beyond, 51 STAN. L. REV. 1 (1998); Patricia M. Wald, The Sizzling Sleeper: The Use of Legislative History in Construing Statutes in the 1988-89 Term of the United States Supreme Court, 39 AM. U. L. REV. 277 (1990) [hereinafter Wald, Sizzling Sleeper]; Patricia M. Wald, Some Observations on the Use of Legislative History in the 1981 Supreme Court Term, 68 Iowa L. REv. 195 (1983) [hereinafter Wald, Observations]; Nicholas S. Zeppos, The Use of Authority in Statutory Interpretation: An Empirical Analysis, 70 TEx. L. REV. 1073 (1992).

These studies have shown considerable fluctuation in the frequency with which the Supreme Court relies on legislative history. For example, Judge Wald found that the Court used legislative history in virtually all of its statutory interpretation opinions during the 1981-1982 Term. Wald, Observations, supra, at 195, 197. When she repeated her study for the 1988-1989 Term, however, the percentage of statutory interpretation cases making substantive use of legislative history had fallen to 75 percent. Wald, Sizzling Sleeper, supra, at 288. Tom Merrill found that the number had fallen still further by the 1992-1993 Term, with the Court relying on legislative history in only 18 percent of the cases. Merrill, supra, at 355. Thus, for a time it appeared that legislative history might disappear from the Court's 
years. 46 Critics have worried that once courts leave the text of the statute to examine its legislative history and seek to divine the accompanying legislative intent (assuming that it even makes sense to speak of the collective intent of a legislature engaged in strategic compromise), the potential for confusion only expands. 47

There are, moreover, many different and potentially inconsistent sources of legislative history. Empirical studies of Supreme Court opinions suggest that all of these sources are relied upon to one degree or another. For example, in an analysis of Supreme Court opinions from 1938 to 1979, Jorge Carro and Andrew Brann found that House Report, Senate Report, and Congressional Record citations (primarily to debates) far outnumber other documents. 48 Nick Zeppos found, in a random sample of statutory interpretation cases from 1890 to 1990, that "congressional reports appear in 32 percent of the cases, congressional debates in 16.9 percent of the cases, and congressional hearings in 12.6 percent of the cases." 49 Thus, while legislative reports, particularly conference committee reports, carry the most weight with the Court, ${ }^{50}$ other sources are also influential.

The Supreme Court has adopted a variety of doctrines for determining the relative weight that courts should give to the different forms of legislative history. ${ }^{51}$ These doctrines are described as guides for courts in determining the meaning of statutes. ${ }^{52}$ The Supreme Court presumably offered these guides in

opinions. More recently, however, Jane Schacter found that the decline of legislative history has been reversed. Studying the 1996-1997 Term, she found that the Court cited legislative history in 49 percent of its statutory interpretation cases. Schacter, supra, at 15. So legislative history continues to matter to the Supreme Court, although perhaps not as much as it once did. Lower courts, wary of reversal, are therefore likely to bolster their opinions with references to legislative history to show that their decisions are consistent with legislative intent.

46. See, e.g., Frank H. Easterbrook, Text, History, and Structure in Statutory Interpretation, 17 HARV. J.L. \& PUB. POL'Y 61, 69 (1994) ("When the text has no answer, a court should not put one there on the basis of legislative reports or moral philosophy-or economics! Instead the interpreter should go to some other source of rules, including administrative agencies, common law, and private decision.").

47. See generally MikVA \& LANE, supra note 1, at 757-97.

48. Carro \& Brann, supra note 45, at 299 (finding that these sources constitute 65 percent of legislative history sources cited).

49. Zeppos, supra note 45, at 1093. Randy Quinn found a similar hierarchy of sources in securities cases decided by the Court. Quinn, supra note 45, at 265-66 ("The materials discussed by the Court, in order of frequency of occurrence, include committee reports, hearings, prior drafts, post-enactment materials, and floor statements.").

50. See Wald, Observations, supra note 45, at 201 ("Committee reports indeed remain the most widely accepted indicators of Congress' intent. Conference committee reports and statements of floor managers are considered particularly weighty.").

51. We discuss those doctrines and apply them to the specific example of the legislative history of the Reform Act's pleading standard in the next Part.

52. Which, of course, assumes that there is meaning to be discovered. That may not 
the hope that lower courts would reach the same interpretation that the Supreme Court would reach if it addressed the question. ${ }^{53}$ Critically, however, those doctrines are styled as presumptions, with no source of legislative history taking absolute priority over any other. For example, conference committee reports are ordinarily entitled to the greatest weight, 54 but courts can place greater weight on other sources when they consider those sources more relevant. As a result, the rules that the Court relies upon to determine the relative weight to be given to different pieces of legislative history are inherently plastic. If the rules of statutory construction actually confer discretion, then judges are free to approach legislative history with a great deal of flexibility.

The diversity of sources relied upon by the Supreme Court has important strategic consequences for Congress. Members of Congress clearly are aware that legislative history provides a menu of means by which they can signal their preferences to the courts. They therefore attempt to sneak interpretations into footnotes of reports, insert statements into the Congressional Record contradicting the interpretation found in the committee report, and engage in colloquies intended to influence judicial interpretation.55 Because the Court relies on presumptions rather than strict rules of priority to determine the weight to be given to sources of legislative history and because courts have flexibility in deciding when a rule or presumption applies, the result of this legislative gamesmanship can be a legislative history that offers no clear direction on congressional intent. Why, then, would courts rely on such unreliable and manipulable evidence?

\section{Judicial Responses to Ambiguity: The Institutional Perspective}

Formally, the interpretive techniques of statutory construction may be motivated by a desire to generate consistent interpretations of statutory text.

always be the case. See Grundfest, supra note 17, at 42 .

The demand for judicial interpretation of legislative inkblots has spawned a cottage industry that generates rules, standards, and principles for the interpretation of vague or incomplete legislative language.... But no matter how cogent, this literature cannot paper over the fact that many principles of statutory construction are, at root, efforts to impose meaning where there is none.

Id.

53. Schacter, supra note 45 , at 13 ("The interpretive resources that appear in Supreme Court opinions help to set the boundaries for statutory interpretation by legitimating particular resources and approaches. Further, the Court's opinions offer guidance to lower courts, lawyers, and litigants.").

54. See Thornburg v. Gingles, 478 U.S. 30, 44 n.7 (1986) ("We have repeatedly recognized that the authoritative source for legislative intent lies in the committee reports on the bill."); MIKVA \& LANE, supra note 41, at 36.

55. All of these stratagems allegedly were employed in the crafting of the Reform Act's legislative history. See infra notes $114,118,140,144$ and accompanying text. 
Pragmatically, judges, including Supreme Court justices, may value a level of discretion that conflicts with the formal goal of precision. The formal judicial emphasis on discerning a statute's "clear meaning" may therefore not accurately reflect the judiciary's true objective function.

Judge Harold Leventhal's cynical view, so delightfully phrased that it has become a cliché in articles on legislative history, suggests that citing legislative history is akin to "looking over a crowd and picking out your friends." 56 Perhaps judges who rely on legislative history do so because they value their own ability to exercise discretion and can always find a "friend" in the legislative history. Moreover, as long as the Supreme Court is not too choosy about how you pick your friends, the standards of statutory construction can still allow substantial room for the exercise of discretion. ${ }^{57}$ Indeed, the doctrines supporting the use of legislative history are so flexible that even advocates of the use of legislative history concede that it can or should be ignored if it does not help in interpretation..$^{58} \mathrm{~A}$ skeptic might thus suggest that the courts rely on legislative history because it can be manipulated to give judges maximum freedom in interpreting statutes. If so, rules of statutory interpretation are unlikely to produce a determinative answer when Congress has enacted an ambiguous statute.

Assessing the possibility that the dominant rules of statutory construction fail to constrain (or only weakly constrain) judicial discretion requires a theory of judicial behavior. Federal judges are cut off from the usual incentives of monetary gain and the quest for reelection. Explaining and predicting their behavior is therefore a difficult task. ${ }^{59}$ Academic theories of judicial motivation have revolved around two competing models: (1) the "attitudinal model," a descendant of legal realism popular among political scientists, which holds that judges decide cases in ways that further their ideological preferences; and (2) the "legal model," a descendant of legal formalism, favored more often by judges and legal scholars, which holds that judicial decisions are derived from reasoned arguments based on traditional legal tools such as text and

56. As reported in Wald, Observations, supra note 45, at 214.

57. See Zeppos, supra note 45 , at 1124 ("The sheer range of sources of perfectly acceptable pedigree means that judges will rarely have to stray too far to find support for even their most controversial conclusions.").

58. See Stephen Breyer, On the Uses of Legislative History in Interpreting Statutes, 65 S. CAL. L. REV. 845, 862 (1992) ("One can easily find examples of vague or conflicting legislative history. The critics do so, and they cite them. ... L Logically, the argument is open to the response, 'If the history is vague, or seriously conflicting, do not use it.' No one claims that history is always useful; only that it sometimes helps.").

59. See generally Donald J. Boudreaux \& A.C. Pritchard, Reassessing the Role of the Independent Judiciary in Enforcing Interest-Group Bargains, 5 CONST. POL. ECON. 1 (1994) (describing difficulties Congress has in controlling judges); Richard A. Epstein, The Independence of Judges: The Uses and Limitations of Public Choice Theory, 1990 BYU L. REV. 827 (discussing institutional constraints on judicial self-interest). 
precedent.60 Political scientists claim empirical support for the attitudinal model, ${ }^{61}$ and it can be said to have attained the level of an article of faith in that discipline.62 More recently, law professors have begun to test the claims of the attitudinal model as empirical work has become a more important part of legal scholarship. 63 These studies have provoked some rather heated responses by

60. Lee Epstein \& Tracey E. George, On the Nature of Supreme Court Decision Making, 86 AM. POL. SCI. REV. 323 (1992).

61. See, e.g., C.K. Rowland \& RoBERT A. CARP, Politics AND JUdGMENT IN FEDERAL DISTRICT COURTS (1996); see also Tracey E. George, The Dynamics and Determinants of the Decision To Grant En Banc Review, 74 WASH. L. REV. 213, 238-39 nn.128-30 (1999) (collecting studies).

62. Rowland and Carp, for example, ask the rhetorical question: "Does anyone doubt ... that the Clinton appointees to the district courts will be more supportive of civil rights claims and underdog claims in general than are their brethren appointed by Presidents Reagan and Bush?" RowLAND \& CARP, supra note 61, at vii-viii.

63. See Orley Ashenfelter, Theodore Eisenberg \& Stewart J. Schwab, Politics and the Judiciary: The Influence of Judicial Background on Case Outcomes, 24 J. LEGAL STUD. 257 (1995) (studying effect of judicial attitudes on civil rights cases); James J. Brudney, Sara Schiavoni \& Deborah J. Merritt, Judicial Hostility Toward Labor Unions? Applying the Social Background Model to a Celebrated Concern, 60 OHIO ST. L.J. 1675 (1999) (studying the effect of judicial background on appellate court review of NLRB decisions); Frank B. Cross \& Emerson H. Tiller, Judicial Partisanship and Obedience to Legal Doctrine: Whistleblowing on the Federal Courts of Appeals, 107 YALE L.J. 2155 (1998) (studying adherence to precedent in judicial review of agency decisionmaking); Frank B. Cross \& Emerson H. Tiller, The Three Faces of Federalism: An Empirical Assessment of Supreme Court Federalism Jurisprudence, 73 S. CAL. L. REv. 741 (2000) (studying federalism decisions by the Supreme Court); Theodore Eisenberg \& Sheri Lynn Johnson, The Effects of Intent: Do We Know How Legal Standards Work?, 76 CORNELL L. REV. 1151 (1991) (studying effect of judicial attitudes on outcomes in racial discrimination suits); Tracey E. George, Developing a Positive Theory of Decisionmaking on U.S. Courts of Appeals, 58 OHIo ST. L.J. 1635 (1998) (studying decisions by en banc courts of appeals); George, supra note 61 (studying decisions to grant en banc review); Joseph D. Kearney \& Thomas W. Merrill, The Influence of Amicus Curiae Briefs on the Supreme Court 148 U. PA. L. Rev. 743 (2000) (studying effect of amicus briefs on Supreme Court decisions); John R. Quinn, "Attitudinal" Decision Making in the Federal Courts: A Study of Constitutional SelfRepresentation Claims, 33 SAN DIEGO L. REV. 701 (1996) (studying decisions on assertion of right of self-representation by criminal defendants); Richard L. Revesz, Environmental Regulation, Ideology, and the D.C. Circuit, 83 VA. L. REV. 1717 (1997) (studying effect of ideology on judicial review of EPA action); Richard L. Revesz, Strategic Voting on the D.C. Circuit?: A Case Study of Challenges to Health-and-Safety Regulation, 76 N.Y.U. L. REV. (forthcoming 2001) (studying the effect of the composition of Congress on D.C. Circuit review of agency decisions); Vicki Schultz \& Stephen Petterson, Race, Gender, Work, and Choice: An Empirical Study of the Lack of Interest Defense in Title VII Cases Challenging Job Segregation, 59 U. CHI. L. REV. 1073 (1992) (studying effect of judicial background on anti-discrimination suits); Sisk et al., supra note 21 (studying district court decisions on the constitutionality of the Sentencing Guidelines).

John Allison and Mark Lemley do not control for ideological influences in their empirical study of patent validity decisions because the Federal Circuit is so heavily Republican and because of their skepticism that ideology has much influence on patent law. John R. Allison \& Mark A. Lemley, How Federal Circuit Judges Vote in Patent Validity Cases, 27 FlA. ST. U. L. REv. 745, 752 n.27 (2000). 
federal judges defending the paramount role of formal legal sources in judicial decision-making. ${ }^{64}$

The gap between the formalist norms of the legal model, requiring adherence to external authority, and the realpolitik of the attitudinal model, positing that judges pursue ideological preferences, is potentially quite large. If the rules of statutory construction are sufficiently flexible, however, legislative history may provide judges with a means to bridge that gap. Indeed, even those judges who defend the formalist model concede that judicial attitudes play a role when the traditional tools of decision making provide no clear answer. 65 Legislative history, when filtered through the Supreme Court's potentially elastic rules governing its use, can allow legislators to provide judges with useful materials to justify their decisions, without actually constraining those decisions. ${ }^{66}$ Legislators may be able to politicize judicial decision-making simply by injecting ambiguity into statutes and their accompanying legislative histories. To paraphrase Judge Leventhal, perhaps legislators use legislative history to provide "friends" to judges who share their policy outlook. The real battle, then, in the creation of legislative history, is the contest between the opposing factions to provide like-minded judges with more and better interpretive "friends."

How can this factional infighting be reconciled with the formalist norms that judges espouse? As previously suggested, Judge Posner's conceptualization of judging as a game produces a useful frame of analysis. ${ }^{67}$ In Posner's model, judges rely on traditional legal materials in deciding cases because deciding within the rules is an important part of what makes judging challenging and interesting. Posner's model comports with the notion of

64. See Harry T. Edwards, Collegiality and Decision Making on the D.C. Circuit, 84 VA. L. ReV. 1335 (1998); Patricia M. Wald, A Response to Tiller and Cross, 99 CoLUM. L. REv. 235 (1999). Revesz replies in Richard L. Revesz, Ideology, Collegiality, and the D.C. Circuit: A Reply to Chief Judge Harry T. Edwards, 85 VA. L. REV. 805 (1999). See also ROWLAND \& CARP, supra note 61, at 17 ("[T] he assumption that all federal trial judges are motivated by extralegal, personal preferences is contrary to what studies of judicial role models have concluded, and it also gives offense to judges themselves, who consistently deny such an assertion.").

65. See Wald, supra note 64, at 236 ("I register something of a ho-hum reaction to the notion that judges' personal philosophies enter into their decision making when statute or precedent does not point their discretion in one direction or constrain it in another. Judges would be rudderless ships if we did not steer through uncharted and murky waters by some sense of conscience or some core of personal beliefs.").

66. Cf. Schacter, supra note 45 , at 54 ("[L]egislative history can be ... seen as one source of information and guidance-among many-in a pragmatic exercise. It is neither a source that trumps language, nor one that ... is entitled to dispositive weight as evidence of singular intent that most often does not exist.").

67. POSNER, supra note 9, at 131 ("The pleasure of judging is bound up with compliance with certain self-limiting rules that define the 'game' of judging."). 
professionalism common to participants in many learned activities.68 Any hack can decide a case according to his knee-jerk reaction to the issue presented; it takes real skill and judgment to decide the case on a legal basis. The elasticity of legislative history can thus be viewed as expanding the boundaries of the game, particularly when statutory text is ambiguous. Judges must necessarily interpret statutes in the course of resolving disputes. The judge who relies on congressional intent as expressed in some portion of the legislative history when interpreting a statute cannot be criticized as willfully flouting the clear language by his fellow judges or lawyers because he can point to external (i.e., formal) authority in support of his decision. 69 This flexibility allows the judge to further his policy preferences while maintaining the professional respectability that comes with reliance on formal legal authority.70 If a lower court judge finds himself being reversed on an issue of statutory interpretation, his fellow judges are unlikely to think that his failure to focus in on the favored portion of legislative history shows incompetence or willfulness. Perhaps just as importantly, being able to point to an external source for the decision (particularly one with its source in the democratically elected legislature) allows the judiciary to maintain its legitimacy in the eyes of the public and the other branches of government. ${ }^{71}$

68. See, e.g., Ronald Gilson \& Robert Mnookin, Disputing Through Agents: Cooperation and Conflict Between Lawyers in Litigation, 94 COLUM. L. REV. 509 (1994).

69. See Ronald A. Cass, Judging: Norms and Incentives of Retrospective DecisionMaking, 75 B.U. L. REV. 941, 973 (1995) ("The appearance of operating according to set rules and under external constraints also is important to judges (individually and as a class), as it insulates them against many types of criticism. While ' $I$ was only following orders' may not be a complete defense in all circumstances, it has strong intuitive appeal."); see also Cornell W. Clayton, Separate Branches-Separate Politics: Judicial Enforcement of Congressional Intent, 109 POL. SCI. Q. 843 (1994-1995); Lori Hausegger \& Lawrence Baum, Inviting Congressional Action: $A$ Study of Supreme Court Motivations in Statutory Interpretation, 43 AM. J. POL. SCI. 162 (1999).

70. See PosNer, supra note 9, at 131 ("Playing by the rules is also consistent with judges' often voting their policy preferences and personal convictions. For in our system the line between law and policy, the judging game and the legislating game, is blurred. Many cases cannot be decided by reasoning from conventional legal materials. Such cases require the judge to exercise a legislative judgment, although a more confined one than 'real' legislators are authorized to exercise."); Sidney A. Shapiro \& Richard E. Levy, Judicial Incentives and Indeterminacy in Substantive Review of Administrative Decisions, 44 DUKE L.J. 1051, 1058 (1995) ("[J]udges who ignore clear craft norms in order to pursue an outcome orientation are likely to suffer a loss of respect among fellow jurists, lawyers, and the public.").

71. See Frank B. Cross, Political Science and the New Legal Realism: A Case of Unfortunate Interdisciplinary Ignorance, 92 Nw. U. L. REV. 251, 272-73 (1997) (discussing the perception of external constraints on decisions as being essential to judicial legitimacy). 


\section{E. Equilibrium}

Based on these observations, we hypothesize an interactive-interpretive equilibrium in which the forces that are charged with seeking clarity (the judiciary) are arrayed against forces that prefer ambiguity (the legislature). Each is, moreover, acting "in the shadow" of the other, because each institution understands the incentives that govern the other's operation. ${ }^{72}$ Without delving further into the incentives facing each branch, there is no reason to conclude that, at any one point in time or with respect to any specific statutory language or history, the forces of ambiguity will prevail over those that seek precision.

The incentives facing the legislature, however, are clear. Legislators want to be able to compromise by enacting ambiguous statutes. A statute is credibly ambiguous only if the judiciary lacks an interpretive technology that can quickly ascribe precise meaning to the text and legislative history.

The incentives facing the judiciary are more complex. The formalist canon calls for precise rules of interpretation and consistent application of these interpretive principles. However, institutional factors and personal proclivities suggest a judicial preference for standards over rules and for ambiguity over precision in statutory design and interpretation.

The legislative preference for ambiguity can be effective only if the judiciary cooperates by not adopting interpretive techniques that are too strict. Otherwise, the mixed strategies necessary to attain ambiguous compromises would be impossible. If this analysis is correct, then the equilibrium between the legislative incentive to obscure and the formal judicial interpretive norm may well be tilted in favor of the legislature's goal of ambiguity because that result promotes judicial objectives as well. ${ }^{73}$ Judicial tolerance of legislative ambiguity could then reflect a mutually advantageous exchange between the legislative and judicial branches.

Although this theoretical perspective suggests that the forces of ambiguity have an advantage over the goal of interpretive consistency, the question remains empirical. Testing the nature of this equilibrium requires the identification of a statute that was crafted to be ambiguous in order to

72. This notion of equilibrium extends only to situations involving intentional legislative ambiguity. It does not seek to address interpretive challenges raised by the natural limits of language; changed social, economic, technological, or legislative circumstances; legislative oversight; ambiguity consistent with an intent to delegate to any administrative agency or other sources of interpretive confusion. See, e.g., H.L.A. HART, THE CONCEPT OF LAW 124-36 (2d ed. 1994); David Lyons, Open Texture and the Possibility of Legal Interpretation (Apr. 18, 2000), Boston Univ. School of Law Working Paper No. 999, available at http://papers.ssm.com/sol3/papers.cfm?abstract_id=212328 .

73. See Anthony D'Amato, Can Legislatures Constrain Judicial Interpretation of Statutes?, 75 VA. L. REV. 561, 602 (1989) ("[I]f there is a reigning jurisprudence among the judges of the day, the legislature will be more effective in writing its statutes if it knows what this jurisprudence is and how to exploit it."). 
implement a legislative compromise. It then requires the analysis of a large number of independent decisions all interpreting the same text. We demonstrate in Part III that the "strong inference" provision of the PSLRA provides just such a test case.

\section{THE “STRONG INFERENCE” PLEADING STANDARD UNDER THE PSLRA}

In this Part, we describe the legislative evolution of the "strong inference" pleading standard of the PSLRA. We document extensive efforts by competing interests to fashion statutory language and legislative history to suit competing objectives and we relate those efforts to the relevant principles of statutory construction as applied by the courts. We also present evidence, rooted in the Senate's decision to override a presidential veto by a single vote, that the legislation would not have been enacted but for an agreement to disagree over the meaning of the "strong inference" provision. In addition, we discuss congressional efforts to influence the interpretation of the "strong inference" provision through the creation of post-enactment legislative history.

This legislative saga provides substantial evidence that congressional combatants are well informed regarding the principles of statutory construction that will later be applied by the courts. Their efforts constitute an elaborate attempt to build a record that can be interpreted in their constituencies' favor in subsequent disputes before the courts. The open empirical question, which we address in Part IV and in the Appendix to this Article, is whether these efforts to obscure are successful (in which case we should observe a range of interpretations at the district court level and significant splits at the circuit court level) or whether they fail (in which case the courts should coalesce on a consistent interpretation of the statutory language).

\section{A. Background to Legislative Action}

The story of the Reform Act's pleading standard begins with the Supreme Court's 1976 decision in Ernst \& Ernst v. Hochfelder, which held that merely negligent misstatements would not establish liability under Section 10(b) of the Securities Exchange Act of 1934 ("Exchange Act"). ${ }^{74}$ Instead, plaintiffs were required to establish that the defendants acted with "scienter," defined by the Court as misconduct that was "knowing or intentional."75 The Court left open the possibility that "recklessness" might satisfy this state of mind requirement, but it did not define the requisite degree of "recklessness." The Court has twice expressly declined to address whether recklessness establishes the

74. 425 U.S. 185,197 (1976).

75. Id.

76. Id. at $193 \mathrm{n} .12$. 
requisite scienter. ${ }^{77}$

Since Hochfelder, every court of appeals that has addressed the issue has held that recklessness satisfies the scienter requirement of Section $10(b){ }^{78}$ This surface unanimity among the circuits, however, masks considerable divergence of opinion as to the precise definition of recklessness that supports liability. ${ }^{79}$ While some courts apply a "barely reckless" standard, other courts lean toward a "highly reckless" standard 80 Some courts speak of recklessness as "carelessness approaching indifference," 11 or as existing when defendants "had reasonable grounds to believe material facts existed that were misstated or omitted, but nonetheless failed to obtain and disclose such facts although they could have done so without extraordinary effort.' $\$ 2$ Other courts are more demanding, insisting upon "a lesser form of intent [rather] than merely a greater degree of ordinary negligence," 83 or on a showing of "severe recklessness." 84 The result of this confusion is that there is "little uniformity ... among the circuits or even among different panels on the same circuit, on how proof of recklessness should be used to satisfy scienter.' $\$ 85$ Worse still than this lack of uniformity is the risk that lower courts have allowed "a negligence-like standard [to creep] back into 10b-5 actions, and the subjective focus of the scienter requirement imposed by Hochfelder has been undermined." 86 The standard used by some lower courts raises the possibility

77. Id. at 193; see also Aaron v. SEC, 446 U.S. 680,686 n.5 (1980).

78. See, e.g., Hollinger v. Titan Capital Corp., 914 F.2d 1564, 1568-70 (9th Cir. 1990) (en banc), cert. denied, 499 U.S. 976 (1991); McDonald v. Alan Bush Brokerage Co., 863 F.2d 809, 814 (11 th Cir. 1989); In re Phillips Petroleum Sec. Litig., 881 F.2d 1236, 1244 (3d Cir. 1989); Hackbart v. Holmes, 675 F.2d 1114, 1117-18 (10th Cir. 1982); G.A. Thompson \& Co. v. Partridge, 636 F.2d 945, 962 n.32 (5th Cir. 1981); Stokes v. Lokken, 644 F.2d 779, 783 (Sth Cir. 1981); Mansbach v. Prescott, Ball \& Turben, 598 F.2d 1017, 1025 (6th Cir. 1979); Rolf v. Blyth Eastman Dillon \& Co., 570 F.2d 38, 47 (2d Cir. 1978); Cook v. Avien, Inc., 573 F.2d 685, 692 (1st Cir. 1978); Sanders v. John Nuveen \& Co., 554 F.2d 790, 79293 (7th Cir. 1977), cert. denied, 450 U.S. 1005 (1981).

79. It also does not necessarily imply that the high court agrees with the unanimous view of the courts of appeals. Cf. Central Bank of Denver v. First Interstate Bank of Denver, 511 U.S. 164 (1994) (rejecting unanimous view of courts of appeals that Section 10(b) supported liability for aiding and abetting securities fraud).

80. 2 Thomas Lee hazen, Treatise on the LaW of Securities Regulation 83 (2d ed. 1990).

81. Hoffman v. Estabrook \& Co., 587 F.2d 509, 516 (lst Cir. 1978) (quoting lower court opinion).

82. Kiernan v. Homeland Inc., 611 F.2d 785, 788 (9th Cir. 1984).

83. Sanders v. John Nuveen \& Co., 554 F.2d 790, 793 (7th Cir. 1977), cert. denied, 450 U.S. 1005 (1981).

84. Broad v. Rockwell Int'l Corp., 642 F.2d 929, 961-62 (5th Cir.), cert. denied, 454 U.S. 965 (1981).

85. Paul S. Milich, Securities Fraud Under Section 10(b) and Rule 10b-5: Scienter, Recklessness, and the Good Faith Defense, 11 J. CoRP. L. 179, 180 (1986).

86. Id. at $180-81$. 
that subjectively honest, but incorrect, statements could give rise to liability. Such a standard (combined with the enormous damages available in securities fraud cases) threatens, in the view of critics, to chill corporate speech relevant to investors and thereby reduce the information contained in securities prices.

While the definition of recklessness divided the courts of appeals prior to the Reform Act, they disagreed even more sharply on the question of what was required to plead scienter. Rule $9(\mathrm{~b})$ of the Federal Rules of Civil Procedure requires that plaintiffs plead the circumstances giving rise to a claim of fraud "with particularity," but allows state of mind to be "averred generally.' 87 Prior to the Reform Act, the Second Circuit held that pleading scienter under the Rule requires "plaintiffs to allege facts that give rise to a strong inference of fraudulent intent." 88 The Ninth Circuit disagreed, finding the Second Circuit's interpretation inconsistent with the plain language of Rule $9(\mathrm{~b})$. The Ninth Circuit instead held that plaintiffs could adequately plead a complaint simply by "saying that scienter existed." 89 The Reform Act purported to resolve this conflict by adopting a uniform standard for pleading scienter, the "strong inference" standard. 90

The issue of pleading scienter in a federal securities law complaint that raises a claim of reckless conduct thus implicates three distinct levels of ambiguity. First, does scienter encompass recklessness? Second, if recklessness constitutes scienter, how is recklessness defined? Third, even if we assume that recklessness constitutes scienter and even if recklessness can be consistently defined, what pleading standard must be satisfied in order for a complaint to withstand a motion to dismiss? The battle over the "strong inference" standard, while technically raising only the third question, therefore also unavoidably involved strategic maneuvering over the predicate state of mind requirement. The stakes of this legislative game were thus much greater than the articulation of a simple pleading standard.

\section{B. The Reform Act and the "Strong Inference" Standard}

The "strong inference" pleading standard had its genesis early in the drafting of the PSLRA. The initial House version of the bill that eventually became the Reform Act would have required a showing of actual knowledge, thereby eliminating liability for reckless conduct. ${ }^{91}$ The bill eventually passed

87. FED. R. Crv. P. 9(b).

88. Shields v. Citytrust Bancorp, Inc., 25 F.3d 1124, 1128 (2d Cir. 1994).

89. In re Glenfed, Inc. Sec. Litig., 42 F.3d 1541, 1547 (9th Cir. 1994) (en banc).

90. Private Securities Litigation Reform Act $\S 21 \mathrm{D}(\mathrm{b})(2)$ (codified at 15 U.S.C. $\$ 78 \mathrm{u}-$ $4(b)(2)$ ) (requiring that the plaintiff's complaint in a private action "state with particularity facts giving rise to a strong inference that the defendant acted with the required state of mind").

91. Common Sense Legal Reforms Act of 1995, H.R. 10, 104th Cong. $§ 10 A(a)(2)$ 
by the House, however, instead codified recklessness as "[d]eliberately refraining from taking steps to discover whether one's statements are false or misleading." 92 This attempt at codification did not survive the legislative process.

The Reform Act's "strong inference" standard for pleading scienter originated in S. 240, the Senate precursor to the Act.93 The Senate Banking Committee's report makes clear that Congress modeled the Act's pleading standard on that of the Second Circuit, ${ }^{94}$ but there was also uncertainty as to the precise definition of the "strong inference" standard that was required by the Second Circuit. Indeed, there was reason to believe that the standard had at least three different articulations. ${ }^{95}$

If the text of the Reform Act and the Senate report were the only materials available to courts interpreting the Reform Act, there is a reasonable probability that courts would have construed it as adopting the Second Circuit standard for pleading scienter, although there could have been residual uncertainty about how that standard should be interpreted and applied. Prior to the passage of the Reform Act, and according to one articulation of the standard, the Second Circuit had construed the "strong inference" standard as being met, in the absence of direct evidence of the defendant's intent, by either (1) strong circumstantial evidence of conscious or reckless misbehavior, or (2) facts showing motive and opportunity to commit the fraud. ${ }^{96}$ Absent contrary evidence, courts ordinarily presume that Congress intended to adopt the settled judicial construction of a rule when it has incorporated that standard into a statute. 97 On the other hand, because the Second Circuit standard can be

(1995) (requiring proof that defendant "knew [his] statement was misleading at the time ... made, or intentionally omitted to state a fact knowing that such omission would render [his statement] misleading" (emphasis added)).

92. Securities Litigation Reform Act, H.R. 1058, 104th Cong. $\$ 10 A(a)(4)$ (1995) (as passed by the House).

93. Private Securities Litigation Reform Act of 1995, S. 240, 104th Cong. $§ 36(\mathrm{~b})$ (1995) (as reported in the Senate, June 19, 1995) (requiring that the complaint "specifically allege facts giving rise to a strong inference that the defendant acted with the required state of mind").

94. The report states:

The committee does not adopt a new and untested pleading standard that would generate additional litigation. Instead, the Committee chose a uniform standard modeled upon the pleading standard of the Second Circuit. Regarded as the most stringent pleading standard, the Second Circuit requires that the plaintiff plead facts that give rise to a "strong inference" of defendant's fraudulent intent. The Committee does not intend to codify the Second Circuit's case law interpreting this pleading standard, although courts may find this body of law instructive.

S. REP. No. 104-98, at 15 (1995) (footnotes omitted).

95. See In re Silicon Graphics Inc. Sec. Litig., 970 F. Supp. 746, 755 (N.D. Cal. 1997).

96. Shields v. Citytrust Bancorp, Inc., 25 F.3d 1124, 1128 (2d Cir. 1994).

97. See Cottage Sav. Ass'n v. Comm'r, 499 U.S. 554, 562 (1991) ("Because these decisions were part of the 'contemporary legal context' in which Congress enacted [the 
interpreted as having at least three different manifestations, ${ }^{98}$ it could also be argued that there was no settled meaning. So even if Congress intended that courts adopt the Second Circuit standard, Congress did not specify which version of the standard it sought to apply.

The situation is further complicated by the fact that inferences to be drawn from the Senate report are contradicted by subsequent developments in the legislative history. Senator Arlen Specter attempted to make the law's reliance on the Second Circuit tests more explicit. He offered a floor amendment that would have provided:

[A] strong inference that the defendant acted with the required state of mind may be established either-

(A) by alleging facts to show that the defendant had both motive and opportunity to commit fraud; or

(B) by alleging facts that constitute strong circumstantial evidence of conscious misbehavior or recklessness by the defendant. ${ }^{99}$

The Senate adopted the Specter amendment, ${ }^{100}$ but the conference committee deleted it, thus reverting to the formulation adopted by the Senate Banking Committee. 101

The defeat of the Specter amendment is susceptible to at least two different interpretations. The first is that Congress was not willing to define the Second Circuit standard with any greater precision. The second is that Congress intended to reject Second Circuit precedent altogether as a basis for the interpretation of the "strong inference" provision. Indeed, Supreme Court precedent suggests that when Congress expressly declines to adopt specific statutory language, "its action strongly militates against a judgment that Congress intended a result that it expressly declined to enact."102 Because the

statute]... we may presume that Congress intended to codify these principles ...."); Lorillard v. Pons, 434 U.S. 575, 581 (1978) ("[W]here, as here, Congress adopts a new law incorporating sections of a prior law, Congress normally can be presumed to have had knowledge of the interpretation given to the incorporated law, at least insofar as it affects the new statute.").

98. See In re Silicon Graphics, 970 F. Supp. at 755.

99. 141 CONG. REC. S9,222 (1995).

100. 141 CONG. REC. S9,200 (1995).

101. The conference committee also changed the language of the standard from "specifically allege" to "state with particularity" based on the recommendation of the Judicial Conference that the provision be amended to conform to Rule 9(b)'s particularity language. 141 CONG. REC. S19,066-67 (1995). It does not appear that the conference committee intended any substantive change from the prior version of the bill.

102. Gulf Oil Corp. v. Copp Paving Co., 419 U.S. 186, 200 (1974); see also INS v. Cardoza-Fonseca, 480 U.S. 421, 442-43 (1987) ("Few principles of statutory construction are more compelling than the proposition that Congress does not intend sub silentio to enact statutory language that it has earlier discarded in favor of other language." (internal quotation marks and citations omitted)). 
conference committee deleted the Specter amendment, courts could therefore presume that Congress did not intend for them to follow the Second Circuit tests that the Specter amendment would have codified.103 The Supreme Court's principles of statutory construction, however, can also be read to allow courts to ignore Congress' rejection of the Specter amendment.104

Further evidence that the conference committee did not want courts to rely on the Second Circuit test can be found in the Statement of Managers:

The Conference Committee language is based in part on the pleading standard of the Second Circuit. The standard also is specifically written to conform the language to Rule 9(b)'s notion of pleading with "particularity."

Regarded as the most stringent pleading standard, the Second Circuit requirement is that the plaintiff state facts with particularity, and that these facts, in turn, must give rise to a "strong inference" of the defendant's fraudulent intent. Because the Conference Committee intends to strengthen existing pleading requirements, it does not intend to codify the Second Circuit's case law interpreting this pleading standard. 105

The last sentence suggests that the conference committee did not want courts following Second Circuit decisions that applied the "strong inference" standard in a less than vigorous fashion. ${ }^{106}$ The last sentence is also consistent with the view that the Committee sought an interpretation more rigorous than even the strictest interpretation that had then been adopted by the Second Circuit. In its more recent pre-Reform Act cases, the Second Circuit had been more demanding, requiring that the plaintiff plead a motive consistent with "informed economic self-interest" and an opportunity to "achiev[e] concrete benefits by the means alleged."107 Unlike the Specter amendment, which could

103. See George A. Costello, Average Voting Members and Other "Benign Fictions": The Relative Reliability of Committee Reports, Floor Debates, and Other Sources of Legislative History, 1990 DUKE L.J. 39, 57 ("[W]eight can be given to Congress's rejection of a bill or amendment if it is clear that Congress considered and rejected the very position argued before the court." (citing Blau v. Lehman, 368 U.S. 403, 411-12 (1962))).

104. See, e.g., Central Bank of Denver v. First Interstate Bank of Denver, 511 U.S. 164,187 (1994) (warning that failed legislative proposals are "a particularly dangerous ground" for statutory interpretation and that "several equally tenable inferences may be drawn from [congressional] inaction, including the inference that the existing legislation already incorporated the offered change").

105. H.R. CONF. REP. No. 104-369, at 41 (1995) (Statement of Managers).

106. See, e.g., In re Time Warner Sec. Litig, 9 F.3d 259, 274 (2d Cir. 1993) (Winter, J., dissenting) (arguing that the majority opinion allowed the motive and opportunity test to be satisfied under circumstances that did not appear likely to produce concrete benefits), cert. denied, 511 U.S. 1017 (1994).

107. Shields v. Citytrust Bancorp, Inc., 25 F.3d 1124, 1130 (2d Cir. 1994) ("[A] plaintiff must do more than merely charge that executives aim to prolong the benefits of the positions they hold."); see also Chill v. Gen. Elec. Co., 101 F.3d 263, 268 (2d Cir. 1996) ("[G]eneralized motive, one which could be imputed to any publicly-owned, for-profit endeavor, is not sufficiently concrete for purposes of inferring scienter."); Acito v. IMCERA Group, Inc., 47 F.3d 47, 54 (2d Cir. 1995) ("[T]he existence, without more, of executive 
have been interpreted as permitting naked allegations of motive and opportunity, this test requires plaintiffs to show a particularized economic benefit that the defendants could rationally expect to achieve through the fraudulent scheme alleged. Thus, one interpretation of the conference committee's deletion of Senator Specter's proposed codification is that the codification would have watered down the Second Circuit standard, and therefore, that the more general formulation adopted would provide a more effective barrier for screening out non-meritorious lawsuits. On this view, by omitting the Specter amendment, the conference committee "strengthened" pleading standards.

This interpretation is undermined, however, by footnote twenty-three of the above-quoted portion of the Statement of Managers, which reads: "For this reason, the Conference Report chose not to include in the pleading standard certain language relating to motive, opportunity, or recklessness." 108 The phrase "for this reason" is, however, vague in context: Is the reason the Committee's intent to strengthen pleading standards to a level more stringent than the Second Circuit's? Or is the reason the Committee's desire to avoid codifying any specific version of the Second Circuit's case law? Footnote twenty-three also seems to conflate the Second Circuit's tests and the cases applying those tests, which were also far from the model of consistency. If the intention is to give courts discretion in deciding whether to follow particular cases from the Second Circuit that apply those tests, then the footnote adds little to the text of the report. On the other hand, if the intention is to avoid the Second Circuit's tests for applying the Second Circuit standard, it is not clear how the Reform Act's standard is "based," even "in part," on the "strong inference" standard: The tests are simply the more particular application of the general standard, not a different rule of law. Renunciation of the tests might, therefore, be considered a renunciation of the standard. These ambiguities are important because the Supreme Court ordinarily considers the conference committee report as the most authoritative evidence, after the statute's text, of legislative intent. ${ }^{109}$ But here the conference committee report arguably confuses at least as much as it clarifies.

The potential difficulties with conference committee reports are well known. As the authors of a leading casebook on legislation point out:

Lobbyists and lawyers maneuver endlessly to persuade staff members (who write the committee reports) and/or their legislative bosses to throw in helpful

compensation dependent upon stock value does not give rise to a strong inference of scienter.").

108. H.R. CONF. REP. No. 104-369, at 49 n.23 (1995).

109. Garcia v. United States, 469 U.S. 70, 76 (1984) ("[T]he authoritative source for finding the Legislature's intent lies in the Committee Reports on the bill, which represen[t] the considered and collective understanding of those Congressmen involved in drafting and studying proposed legislation." (internal quotation marks omitted)). 
language in the reports when insertion of similar language would be inappropriate or infeasible for the statute itself. "Smuggling in" helpful language through the legislative history is a time-tested practice of the D.C. bar. ${ }^{110}$

Interestingly, maneuvering of just this sort is allegedly the source of footnote twenty-three in the Reform Act's conference report. In the debates over the subsequently passed Uniform Standards Act, Representative John Dingell charged that the language of footnote twenty-three had been "slipped into a footnote by a staffer at the last minute without our knowledge or concurrence." 11 If Representative Dingell is correct, the conference report cannot be considered reliable evidence of Congress' intent in adopting the pleading standards. But remarks of individual legislators such as Dingell are entitled to little weight, particularly when made by opponents of the bill, and Dingell opposed the Reform Act.112 The Court apparently recognizes the mischief that would be encouraged by giving credence to statements made by individual opponents of a bill, particularly when made after the fact.113

The presumption that deletion of the Specter amendment implies that Congress did not intend for courts to follow the Second Circuit tests is further muddied by contemporaneous legislative history. In the floor debate over the conference committee's bill, critics charged that the pleading standard would be impossible to meet.114 The conference committee managers rebuffed this criticism in ways that seem to retreat from the conference committee report. Senator Pete Domenici stated, "[T] $]$ he conference report adopts the pleading standard utilized by the second circuit court of appeals." 15 Senator Chris Dodd, another of the managers, agreed that the conference committee had "adopt[ed] the Second Circuit Court of Appeals standard."116 The Supreme

110. William N. Eskridge, JR. \& Philip P. Frickey, Cases and Materials on LEGISLATION 710 (1988).

111. 144 CONG. REC. E2246 (1998).

112. See Bankamerica Corp. v. United States, 462 U.S. 122, 139 (1983) ("[G]reater weight is to be accorded the views of [supporters] concerning the proper interpretation of the original bill than to the views of [opponents].").

113. This has not, however, deterred some lower courts from relying on Dingell's statement. See, e.g., Ganino v. Citizens Utils. Co., 228 F.3d 154, 170 n.11 (2d Cir. 2000).

114. See, e.g., 141 CoNG. REC. S17,960-61 (1995) (statement of Sen. Specter) (criticizing proposed pleading standard as being impossible to meet); 141 CONG. REC. S17,984 (1995) (statement of Sen. Moseley-Braun) (calling new pleading standard significantly higher than the Second Circuit's). These remarks are entitled to little weight.

See Ernst \& Ernst v. Hochfelder, 425 U.S. 185, 203 n.24 (1976) ("Remarks of this kind made in the course of legislative debate or hearings other than by persons responsible for the preparation or the drafting of a bill are entitled to little weight .... This is especially so with regard to the statements of legislative opponents who [i]n their zeal to defeat a bill ... understandably tend to overstate its reach." (internal quotation marks and citations omitted)).

115. 141 CONG. REC. S17,969 (1995).

116. 141 CONG. REC. S17,959 (1995); see also 141 CoNG. REC. S17,934 (Senator 
Court has relied on such statements by individual legislators in attempting to understand how a bill evolved from the original bill to the enacted statute.117 Senators Domenici and Dodd were sponsors of the legislation, and sponsors' remarks are entitled to particular weight. 118 But in cases of conflict between the conference report and statements made during the floor debate, the committee report is ordinarily entitled to precedence. ${ }^{119}$ In this case, however, in light of the post-veto debate explained below, the Reform Act might not have been enacted without Domenici's and Dodd's reassurances, thereby creating an argument that the conference report should not be given greater weight.

The more critical problem with the Specter amendment (not mentioned by the supporters of the bill) is that it could have been construed as implicitly codifying "recklessness" as the liability standard under Section 10(b) of the Exchange Act. As noted above, the Supreme Court has not addressed this question, 120 and the Reform Act goes to lengths to sidestep the issue by using "required state of mind" in the pleading provision, rather than knowledge or recklessness. This formulation has the air of a compromise, suggesting that neither proponents nor opponents of recklessness were capable of garnering a majority (much less a supermajority) for their view. By leaving the question unanswered in the statute, both sides could hope that the Supreme Court would eventually rule in their favor. The Specter amendment threatened to undo that compromise. Therefore, by maintaining the ambiguity of the pleading standard, each side preserved the hope that their view would prevail in the Supreme Court. 121

D'Amato, a manager of the bill, states that its "standard is already the law in New York.").

117. See Mich. Canners \& Freezers Ass'n v. Agric. Mktg. \& Bargaining Bd., 467 U.S. $461,475-76$ (1984) (relying on statements by representatives to understand motivation for amendments).

118. North Haven Bd. of Educ. v. Bell, 456 U.S. 512, 526-27 (1982) ("[R]emarks ... of the sponsor of the language ultimately enacted, are an authoritative guide to the statute's construction."); Nat'1 Woodwork Mfrs. Ass'n v. NLRB, 386 U.S. 612, 640 (1967) ("It is the sponsors that we look to when the meaning of the statutory words is in doubt." (internal quotations marks and citations omitted)). But see William N. Eskridge, Jr., The New Textualism, 37 UCLA L. REV. 621, 644 (1990) ("[B]ecause the sponsor may have a hidden agenda or may be acting pursuant to a secret logroil, the sponsor is often the least likely person to represent the consensus view. [The sponsor] may have uttered the broad language, not because it represented the views of most of his colleagues, but precisely because he realized he did not have the votes to put it in the statute itself.").

119. Zuber v. Allen, 396 U.S. 168, 186 (1969) ("A committee report represents the considered and collective understanding of those Congressmen involved in drafting and studying proposed legislation. Floor debates reflect at best the understanding of individual Congressmen. It would take extensive and thoughtful debate to detract from the plain thrust of a committee report in this instance.").

120. See Aaron v. SEC, 446 U.S. 680, 686 n.5 (1980); Ernst \& Ernst v. Hochfelder, 425 U.S. 185, 193 (1976).

121. The Specter amendment suffered from a related problem: It was inconsistent with 
The Reform Act passed the House by a vote of 320-102. It passed the Senate by a vote of 65-30. The bill was met by the first veto of the Clinton presidency. The veto was overridden in the House by a vote of 319-100 and in the Senate by a vote of 68-30. The loss of even two votes in the Senate due to disagreement over the "strong inference" standard would have doomed the legislation. 122

Significantly, President Clinton's veto message focused directly on the controversy over the meaning of the "strong inference" provision as a basis for the veto. The subsequent debate in connection with the Senate override vote also makes it clear that ambiguity over the definition of "strong inference" was essential in order to maintain the supermajority needed to override the veto.

President Clinton in his veto message stated that he was:

prepared to support the high pleading standard of the U.S. Court of Appeals for the Second Circuit-the highest pleading standard of any Federal circuit court. But the conferees make crystal clear in the Statement of Managers their intent to raise the standard even beyond that level. I am not prepared to accept that.

The conferees deleted an amendment offered by Senator Specter and adopted by the Senate that specifically incorporated Second Circuit case law with respect to pleading a claim of fraud. Then they specifically indicated that they were not adopting Second Circuit case law but instead intended to "strengthen" the existing pleading requirements of the Second Circuit. All this shows that the conferees meant to erect a higher barrier to bringing suit than any now existing-one so high that even the most aggrieved investors with the most painful losses may get tossed out of court before they have a chance to prove their case. ${ }^{123}$

Evidently, the President concluded that the language of the statute and accompanying legislative history would (or at least could) be construed as supporting a standard stronger than the Second Circuit's. But if Congress were to maintain the exquisite ambiguity that had evolved over the interpretation of the "strong inference" provision, then it would not be sufficient to override the President's veto. Instead, proponents of a weaker interpretation of the standard would have to cast doubt on the President's interpretation of the statute, thereby

other provisions of the Reform Act, in that it failed to reflect the fact that recklessness was no longer sufficient for liability under certain circumstances. Congress eliminated recklessness as a basis for liability in cases based upon fraudulent forward-looking statements. Under the Reform Act's safe harbor provision, a plaintiff must prove that a forward-looking statement was made with actual knowledge that it was false or misleading. 15 U.S.C. $\$ 7 \$ u-5(c)(1)(B)$. Because plaintiffs must prove actual knowledge in the case of allegedly misleading forward-looking statements that are covered by the safe harbor, it follows that plaintiffs are now required to plead with particularity facts giving rise to a strong inference that the defendant acted with actual knowledge in such cases.

122. 141 CONG. REC. H15,214 (1995); 141 CONG. REC. S19,180 (1995).

123. 141 CONG. REC. H15,214 (1995). 
suggesting that the President may have vetoed the statute unnecessarily because the "strong inference" provision does not mean what the President thought it meant. At the same time, however, proponents of the stricter interpretation of the statutory language would want to override the veto on the presumption that the Presidential interpretation was correct and that a supermajority in Congress favored that interpretation. ${ }^{124}$

Thus, it should come as little surprise that, in the floor debate following the President's veto, Senator Dodd and the other managers of the Reform Act distanced themselves from the President's interpretation. Dodd argued the President had "reversed course on the pleading standards" that the President had previously endorsed.125 Senator Dodd explained that the conference committee had omitted the Specter amendment because it "did not really follow the guidance of the second circuit."126 In Senator Dodd's view, the Specter amendment "omits that where a motive is not apparent, the strength of circumstantial evidence must be correspondingly greater."I27 The pleading provision, according to Senator Dodd and contrary to the President's belief, "met [the Second Circuit] standard. We have left out the guidance. That does not mean you disregard it."128 The fact that Congress overrode the veto thus gives rise to still another interpretive presumption: In the face of the managers' repudiation of the Statement of Managers, the President's understanding of the Reform Act in his veto message is entitled to little weight. ${ }^{129}$

124. Id.

125. 141 CONG. REC. $S 19,067$ (1995).

126. 141 CONG. REC. $S 19,068$ (1995).

127. Id. Senator Dodd also offered a memorandum written by one of the authors of this Article that characterized the pleading standard as "faithful to the Second Circuit's test." 141 CONG. REC. S19,067 (citing Memorandum from Joseph A. Grundfest, Professor, Stanford Law School, to President William J. Clinton (Dec. 15, 1995)).

128. 141 CoNG. REC. S19,068. Senator Domenici reiterated that the Reform Act's pleading standard "is the Second Circuit's pleading standard" and was a "codification of the Second Circuit rule." 141 CONG. REC. S19,150 (1995). He argued that President Clinton's reliance on the language from the Statement of Managers was misplaced because "[a] statement of managers is not law, everyone knows that." 141 CoNG. REC. S19,045 (1995). Representative Tauzin, another member of the conference committee, also faulted the President for addressing "[n]ot the bill, [but] the statement of the managers." 141 CONG. REC. H15,214 (1995); see also 141 CoNG. REC. H15,218 (statement of Rep. Moran) ("We know we are going to have the Second Circuit standard applied, and that in fact when legislation is at variance with legislative history or report language, that it is the bill itself that prevails.").

129. See NLRB v. Robbins Tire \& Rubber Co., 437 U.S. 214, 235 (1978) (rejecting interpretation in Presidential veto message when supporters of the legislation disagreed with that interpretation of the bill during post-veto debate). 


\section{The Uniform Standards Act}

The Supreme Court's ordinary rule of interpretation is that subsequent legislative history is a poor guide to discerning the intent of the enacting Congress. ${ }^{130}$ Despite this skepticism, the Court has in some cases relied on post-enactment history. ${ }^{131}$ In particular, the Court is more willing to consider post-enactment statements made by sponsors of the legislation, of which Senator Dodd was one. ${ }^{132}$ Moreover, subsequent conference reports, while not entitled to the weight given to subsequent legislation, ${ }^{133}$ may still be entitled to consideration in statutory interpretation, particularly when the intention of the enacting Congress is obscure. 134 There is also empirical evidence that the Supreme Court is more heavily influenced by current legislators' preferences than by the preferences of the legislators who actually wrote the law.135

These observations may help explain the fact that the enactment of the Reform Act in 1995 did not end the stream of legislative history on the pleading standard. Three years later, Congress adopted the Securities Litigation Uniform Standards Act ("Uniform Standards Act"), ${ }_{3}^{136}$ which preempts class actions based on state securities fraud law for certain classes of securities. Congress adopted the Uniform Standards Act in response to the plaintiffs' lawyers' tactic of using state court class actions to evade the obstacles that Congress had erected to federal securities class actions in the Reform Act. 137

130. See, e.g., United States v. Price, 361 U.S. 304, 313 (1960) ("[T]he views of a subsequent Congress form a hazardous basis for inferring the intent of an earlier one.").

131. See, e.g., Loving v. United States, 517 U.S. 748, 768-70 (1996); Bell v. New Jersey and Pennsylvania, 461 U.S. 773, 784-85 \& n.12 (1983).

132. Brock v. Pierce City, 476 U.S. 253, 263-65 (1986); Grove City Coll. v. Bell, 465 U.S. 555, 567 (1984); North Haven Bd. of Educ. v. Bell, 456 U.S. 512, 531 (1982). But see Clarke v. Sec. Indus. Ass'n, 479 U.S. 388, 407 (1987) (refusing to consider sponsor's statement made ten days after the law was enacted).

133. Consumer Prod. Safety Comm'n v. GTE Sylvania, 447 U.S. 102, 118 n.13 (1980) ("Such history does not bear strong indicia of reliability... because as time passes memories fade and a person's perception of his earlier intention may change. Thus, even when it would otherwise be useful, subsequent legislative history will rarely override a reasonable interpretation of a statute that can be gleaned from its language and legislative history prior to its enactment.").

134. See Seatrain Shipbuilding Corp. v. Shell Oil Co., 444 U.S. 572, 596 (1980) ("IW]hile the views of subsequent Congresses cannot override the unmistakable intent of the enacting one, such views are entitled to significant weight, and particularly so when the precise intent of the enacting Congress is obscure." (internal citations omitted)). But see South Carolina v. Regan, 465 U.S. 367, $378 \mathrm{n} .17$ (1984) (rejecting use of "the committee reports that accompany subsequent legislation" as a guide to statutory interpretation).

135. Eskridge, supra note 15 , at 390.

136. Pub. L. No. 105-353, 112 Stat. 3227 (1998).

137. See generally David M. Levine \& Adam C. Pritchard, The Securities Litigation Uniform Standards Act of 1998: The Sun Sets on California's Blue Sky Laws, 54 Bus. LAw. 
The SEC took advantage of Congress' deliberation over the Uniform Standards Act to lobby to protect the recklessness standard, which the agency has long supported. ${ }^{138}$ During the hearings on the bill, the SEC made clear that it would withhold its support from any national fraud standard that did not impose liability upon those who made reckless misrepresentations. 139

In addressing the SEC's concern, the Senate sought to provide assurances in the legislative history that the national standard would include recklessness. The Senate report accompanying the Uniform Standards Act stated that "the PSLRA establish[ed] a uniform federal standard on pleading requirements by adopting the pleading standard applied by the Second Circuit Court of Appeals."140 Senator Dodd also pledged to introduce legislation codifying recklessness if the Supreme Court should ever hold that recklessness does not suffice as a basis for pleading and proving fraud. ${ }^{141}$ This threat of statutory override may well have been intended to influence judicial interpretation. ${ }^{142}$

The Statement of Managers produced by the conference committee that reconciled the House and Senate versions of the Uniform Standards Act was considerably more tepid in its endorsement of the Second Circuit standard and recklessness:

[I]t was the intent of Congress, as was expressly stated during the legislative debate on the Reform Act, and particularly during the debate on overriding the President's veto, that the Reform Act establish a heightened uniform Federal standard on pleading requirements based upon the pleading standard applied

1 (1998).

138. See, e.g., The Securities Litigation Uniform Standards Act of 1997: Oversight Hearing on S. 1260 Before the Sec. Subcomm. of the Comm. on Banking, Hous., and Urban Affairs, 105th Cong. 13 (1997) ("A uniform federal standard that did not include recklessness as a basis for liability would jeopardize the integrity of the securities markets, and would deal a crippling blow to defrauded investors with meritorious claims.").

139. Id. at 14 ("Should the courts of appeals conclude that the Reform Act has somehow eliminated recklessness as a basis for antifraud liability, the preservation of state remedies that allow recovery for reckless conduct would be critical.").

140. S. REP. No. 105-182, at 5-6 (1998) (emphasis added). A colloquy between Senators Dodd and D'Amato on the Senate floor further emphasizes the point:

Mr. D'Amato: I was surprised and dismayed to learn that some district court decisions had not followed the clear language of the ' 95 Reform Act, which is the basis upon which the uniform national standard in today's legislation will be created.

Mr. Dodd: It appears that these district courts have misread the language of the ' 95 Reform Act's Statement of Managers .... I can only hope that when the issue reaches the federal courts of appeals, these courts will undertake a more thorough review of the legislative history and correct these decisions.

144 CONG. REC. S4798-99 (1998).

141. See 144 CONG. REC. S4798 ("[S]hould the Supreme Court eventually find that recklessness no longer suffices to meet the scienter standard, it is my intent to introduce legislation that would explicitly restore recklessness as the pleading and liability standard for federal securities fraud lawsuits.").

142. See generally Eskridge, supra note 15 (studying incidence of congressional overrides of Supreme Court decisions). 
by the Second Circuit Court of Appeals. Indeed, the express language of the Reform Act itself carefully provides that plaintiffs must "state with particularity facts giving rise to a strong inference that the defendant acted with the required state of mind." The Managers emphasize that neither the Reform Act nor S. 1260 makes any attempt to define that state of mind. ${ }^{143}$

Note the subtle shift here: While the Senate report expressed an emphatic intent to "adopt $[\square$ the pleading standard applied by the Second Circuit Court of Appeals," the conference committee report expresses a more ambiguous intent to "establish a heightened uniform Federal standard on pleading requirements based upon the pleading standard applied by the Second Circuit Court of Appeals." Thus, the conference committee report reintroduces the concept that pleading standards had been heightened, apparently a concession extracted by the House managers. ${ }^{144}$ Moreover, the report emphasizes that the Reform Act did not resolve the question of recklessness. Notwithstanding the decidedly mixed signals sent by the conference committee report, the support for recklessness in the Statement of Managers apparently induced the SEC to

143. 144 CoNG. REC. H11,019 (1998). Senators Dodd, D'Amato, and Gramm and Representatives Bliley, Tauzin, Cox, White, and Eshoo served as managers of both acts.

144. See Phyllis Diamond, Uniform Standards Bill Cleared by Congress; Awaits President's Signature, 30 SEC. REG. \& L. REP. 1503 (1988).

To add even more confusion to the legislative history, two members of the conference committee from the House engaged in a colloquy at the time of passage attacking recklessness and the Second Circuit pleading standard. See 144 CoNG. REC. H10,780-81 (1998) (colloquy between Representatives Tom Bliley and Chris Cox). This incident gives weight to the Supreme Court's observation: "To permit what we regard as clear statutory language to be materially altered by such colloquies, which often take place before the bill has achieved its final form would open the door to the inadvertent, or perhaps even planned, undermining of the language actually voted on by Congress . . ." Regan v. Wald, 468 U.S. 222, 237-38 (1984).

Moreover, one of these members inserted a statement arguing there is no statutory basis for liability based on recklessness. 144 CONG. REC. H11,021-22 (1998). The circumstances surrounding the original insertion of this statement into the record, as well as the original printing of the Statement of Managers, were the source of further intrigue. Representative John D. Dingell observed:

The final page [of the Statement of Managers, as originally printed,] mysteriously disappeared. Curiously, this page contained important language regarding scienter, recklessness, and the pleading standard applied by the Second Circuit Court of Appeals, language essential to the conference agreement.... The unidentified material that follows the names of the Managers [i.e., the Bliley Statement], although erroneously printed in the same typeface as the conference report, ... is not part of the conference report's joint explanatory statement and does not represent the views of the Managers. In point of fact, the phantom language directly contradicts the joint explanatory statement ....

144 CONG. REC. E2246 (1998). Both printing errors were subsequently corrected.

Predictably, these moves provoked a flurry of responses. See 144 CONG. REC. S12,906 (1998) (statement of Sen. Reed); 144 CONG. REC. E2296 (1998) (statement of Rep. Eshoo); 144 CONG. REC. S12,738-39 (1998) (statement of Sen. D'Amato); 144 CONG. REC. E2246 (statement of Rep. Dingell); 144 CONG. REC. S12,737 (1998) (statement of Sen. Leahy); 144 CONG. REC. H10,781 (statement of Rep. Markey). 
support the final bill and the President to sign it into law. 145

The question remains, however, whether this asserted reliance by the President and the SEC should be given any weight. If the question of recklessness was that important, why not insist upon that standard being incorporated into the statute when it would have been a simple matter to do so? Even if the Court decides to break from the standard rules of statutory construction and looks to the 1998 Uniform Standards Act to interpret the 1995 "strong inference" provision, it is not at all clear how the 1998 language would tip the scales in the debate. Thus, the import of this post-enactment legislative history is open to doubt, but the time and effort devoted to the creation of this post-enactment history is beyond dispute.

\section{Summary of the PSLRA's Legislative History}

The authors find it difficult to draw any conclusions from this mélange of legislative history about Congress' intent in adopting the "strong inference" pleading standard. Indeed, we disagree as to which interpretation of the "strong inference" standard best fits the statute's text and legislative history. Grundfest believes that the text and history of the Act are more reasonably interpreted to exclude motive and opportunity as well as non-deliberate recklessness from establishing a strong inference of scienter under the Reform Act. Pritchard concludes from the same sources that the more reasonable interpretation is that the establishment of motive and opportunity or non-deliberate recklessness would suffice under the Reform Act.146 Neither author views the other's

145. Statement by President William J. Clinton (Nov. 3, 1998) (signing Uniform Standards Act into law); Letter from Arthur Levitt, Chairman, SEC; Isaac C. Hunt, Jr., Commissioner, SEC; Paul R. Carey, Commissioner, SEC; and Laura S. Unger, Commissioner, SEC, to The Honorable Alfonse M. D'Amato, Chairman, Committee on Banking, Housing \& Urban Affairs and The Honorable Paul S. Sarbanes, Ranking Minority Leader, Committee on Banking, Housing \& Urban Affairs (Oct. 9, 1998).

146. A similar level of disagreement can be found in the plethora of student notes spawned by this dispute. It may be worth noting that the majority of students writing on this topic, like the courts of appeal, favor the intermediate standard. Compare Bradley $\mathrm{R}$. Aronstam, The Private Securities Litigation Reform Act of 1995's Paradigm of Ambiguity: A Circuit Split Ripe for Certiorari, 28 HoFSTRA L. REV. 1061, 1091 (2000) ("The PSLRA's plain language and limited probative legislative history militate in favor of reconciling the circuit split with an intermediate pleading standard of recklessness ...."), Daniel S. Boyce, Pleading Scienter Under the Private Securities Litigation Reform Act of 1995: A Legislative Attempt at Putting Teeth into the Required State of Mind, 35 NEw ENG. L. REV. 761, 802 (2001) (concluding that the Baesa court correctly relied on plain text and ignored legislative history), Nicole M. Briski, Pleading Scienter Under the Private Securities Litigation Reform Act of 1995: Did Congress Eliminate Recklessness, Motive, and Opportunity?, 32 LoY. U. CHI. L.J. 155, 204 (2000) (arguing that the intermediate standard "is consistent with the PSLRA's text, the legislative history of the PSLRA, and the purposes behind the enactment of the PSLRA"), Kim Ferchau, The Circuits Divide: Pleading Scienter Under the Private Securities Litigation Reform Act of 1995, 31 U. ToL. L. REV. 449, 468 (2000) (concluding 
that "plain meaning" of statute which "ignores the tortuous legislative history" requires intermediate standard), Janine C. Guido, Seeking Enlightenment from Above: Circuit Courts Split on the Interpretation of the Reform Act's Heightened Pleading Requirement, 66 BROOK. L. REV. 501, 547 (2000) (determining that policy, plain language, and legislative history favor intermediate standard), Christopher J. Hardy, The PSLRA's Heightened Pleading Standard: Does Severe Recklessness Constitute Scienter?, 35 U.S.F. L. REv. 565, 589 (2001) (concluding that "[a]fter analyzing the statutory language and legislative history, the Eleventh Circuit's interpretation of the PSLRA is most consistent with the language, history, and purpose of the PSLRA"), Lisa A. Herrera, Will Motive, Opportunity or Recklessness No Longer Constitute Scienter for Fraud? A Survey of Recent Federal District Court Decisions After the Enactment of the 1995 Private Securities Litigation Reform Act 26 PEPP. L. REV. 379, 406 (1999) ("[H]igher courts confronted with the issue should use the Baesa holding as a guideline because Baesa's plain language interpretation of the Reform Act imposes natural limits on the lower courts while still championing the main goal of the Reform Act: to curb the filing of frivolous lawsuits."), Chuan $\mathrm{Li}$, Gauging the Hurdle to Strike Suits: Reconciling the Circuit Split over the Proper Interpretation of the Heightened Pleading Standard Under the Private Securities Litigation Reform Act of 1995, 26 J. CORP. L. 435, 454 (2001) (finding that the "plain language" supports intermediate standard), Ryan G. Miest, Would the Real Scienter Please Stand Up: The Effect of the Private Securities Litigation Reform Act of 1995 on Pleading Securities Fraud, 82 MINN. L. REV. 1103, 1120 (1998) (arguing that legislative history and text require courts to adopt intermediate standard), Scott H. Moss, The Private Securities Litigation Reform Act: The Scienter Debacle, 30 Seton HaLl L. REv. 1279, 1319 (2000) ("In light of the various circuit court opinions, the plain meaning of the PSLRA, its legislative history, and the competing public policy regarding securities fraud litigation, it is increasingly evident that the PSLRA raises the procedural requirement of scienter above that of 'motive and opportunity,' while leaving the substantive requirement of recklessness untouched."), Matthew Roskoski, $A$ Case-byCase Approach to Pleading Scienter Under the Private Securities Litigation Reform Act of 1995, 97 MiCH. L. REV. 2265, 2292 (1999) (stating that the intermediate standard "is a direct application of the plain language of the statute"), and Laura R. Smith, The Battle Between Plain Meaning and Legislative History: Which Will Decide the Standard for Pleading Scienter After the Private Securities Litigation Reform Act of 1995?, 39 SANTA ClaRA L. REV. 577, 613 (1999) (advocating intermediate standard based on plain meaning and legislative history), with Eugene P. Caiola, Retroactive Legislative History: Scienter Under the Uniform Security Litigation Standards Act of 1998, 64 ALB. L. REV. 309, 359 (2000) ("The text, legislative history, and normative goals of the PSLRA and the Uniform Act, when considered as a whole, support the adoption of the Second Circuit's pleading standard in addition to the use of the "motive and opportunity' test where those facts demonstrate a 'strong inference of scienter."), Michael A. Dorelli, Striking Back at "Extortionate" Securities Litigation: Silicon Graphics Leads the Way to a Truly Heightened and Uniform Pleading Standard, 31 IND. L. REV. 1189, 1217 (1998) (arguing that the Silicon Graphics "standard is sensitive to the goals of Congress in initiating reform and strikes an appropriate balance between the need to prevent and redress deceptive and manipulative practices in securities litigation, and the maintenance of respectable capital markets"), Michael R. Dube, Motive and Opportunity Test Survives Congressional Death Knell in Private Securities Litigation Reform Act, 42 B.C. L. REv. 619, 647-50 (2001) (criticizing "interpretive mistake" of First, Sixth, and Eleventh Circuits in conceding any relevance to motive and opportunity), Michael B. Dunn, Pleading Scienter After the Private Securities Litigation Reform Act: Or, A Textualist Revenge, 84 CoRNELl L. REV. 193, 250 (1998) (concluding that the "text of [the statute] must ultimately control" interpretation, but that text confers "interpretive discretion" on courts), Bruce Cannon Gibney, The End of the Unbearable Lightness of Pleading: Scienter After Silicon Graphics, 48 UCLA L. REV. 973, 1012, 1014-15 (2001) (advocating 
interpretation as unreasonable.

We suggest that Congress was content to enact an ambiguous statute. The competing attempts to manipulate the Reform Act's legislative history (and subsequent efforts to rewrite that history in the Uniform Standards Act's legislative history) further confuse the question. We also suggest that the legislation would not have been enacted but for the legislative agreement to disagree over the interpretation of the "strong inference" standard. We conclude that the "strong inference" standard satisfies the necessary predicate for a formal test of the judiciary's ability to impute consistent meaning in the face of a legislative intent to obscure in order to maintain a compromise. But how effective is the Reform Act's ambiguous language and conflicting legislative history in creating diverse interpretations in the courts? We turn to that question in Part IV and in the Appendix.

\section{THE APPELlate COURT DeCisions}

We now turn to an empirical analysis of judicial decisions interpreting the "strong inference" standard. There is no United States Supreme Court decision interpreting the "strong inference" standard as of the date of this Article.147 We have, however, identified thirty-three appellate decisions and 167 district court decisions that address the question. We examine the appellate court decisions in this Part, and turn to a statistical analysis of the district court decisions in the Appendix. The appellate court decisions suggest that the congressional ability to obscure has trumped the judicial ability to impose consistent meaning on the legislative text and history of the "strong inference" provision. These decisions also suggest that judges who agree on the interpretation of the "strong inference" standard can disagree on its application. The appellate court data are also weakly consistent with the hypothesis that

Silicon Graphics standard in light of "policy considerations"), Aron Hansen, The Aftermath of Silicon Graphics: Pleading Scienter in Securities Fraud Litigation, 34 U.C. DAvS L. REv. 769,808 (2001) (concluding that "the Ninth Circuit's deliberate recklessness standard is supported by case law, legislative history, and public policy considerations"), and Patricia J. Meyer, What Congress Said About the Heightened Pleading Standard: A Proposed Solution to the Securities Fraud Pleading Confusion, 66 FORDHAM L. REv. 2517, 2557 (1998) (arguing that PSLRA standard is higher than the Second Circuit standard, but Congress should amend the statute to adopt the Second Circuit standard). See also Ann Morales Olazabal, The Search for "Middle Ground": Towards a Harmonized Interpretation of the Private Securities Litigation Reform Act's New Pleading Standard, 6 STAN. J.L. BuS. \& FIN. 153, 196 (2001) (arguing that the initial split among the circuits has been reduced by subsequent cases in which extreme interpretations have been eliminated).

147. Petitions for certiorari raising the question have been filed three time and twice denied. In re Scholastic Corp. Sec. Litig., 252 F.3d 63 (2d Cir. 2001), petition for cert. filed, 70 U.S.L.W. 3164 (U.S. Aug. 30, 2001) (No. 01-397); Desaigoudar v. Meyercord 223 F.3d 1020 (9th Cir. 2000), cert. denied, 121 S. Ct. 1962 (2001); Novak v. Kasaks, 216 F.3d 300 (2d Cir. 2000), cert. denied, 121 S. Ct. 567 (2000). 
ideological factors can play a role in the interpretation of the "strong inference" standard and in the resolution of motions to dismiss.

\section{A. Summary of Appellate Court Decisions}

Table 1 summarizes the thirty-three appellate decisions that address the interpretation of the "strong inference" provision. These decisions arise in ten circuits. Because of the rules of intra-circuit stare decisis, this sample should be viewed as giving rise to ten distinct opportunities for the interpretation of the "strong inference" standard. The leading case that establishes the dominant precedent in each circuit is denoted by an asterisk in Table 1. The additional appellate decisions create opportunities for inconsistent interpretations within a circuit as well as opportunities for the evolution of splits on new issues related to the interpretation and application of the "strong inference" standard. 
Table 1

Appellate Interpretations of the "Strong Inference" Standard (As of November 26, 2001)

\begin{tabular}{|c|c|c|c|c|c|}
\hline Circult & Decision & $\begin{array}{l}\text { Appellate } \\
\text { Interpretive } \\
\text { Standard }\end{array}$ & Result & $\begin{array}{l}\text { District Court } \\
\text { Interpretive } \\
\text { Standard }\end{array}$ & $\begin{array}{l}\text { Nominating } \\
\text { Presidents }\end{array}$ \\
\hline First & $\begin{array}{l}\text { Greebel v. FTP Software, Inc., } \\
194 \text { F.3d } 185(1999)^{*}\end{array}$ & $\begin{array}{l}\text { Intermediate } \\
\text { standard }\end{array}$ & $\begin{array}{l}\text { Affirmed summary } \\
\text { judgment }\end{array}$ & Fails Lowest & $\begin{array}{l}\text { Reagan } \\
\text { Reagan } \\
\text { Clinton }\end{array}$ \\
\hline First & $\begin{array}{l}\text { Geffon v. Micrion Corp., } 249 \\
\text { F.3d } 29 \text { (2001) }\end{array}$ & $\begin{array}{l}\text { Intermediate } \\
\text { standard }\end{array}$ & $\begin{array}{l}\text { Affirmed summary } \\
\text { judgment }\end{array}$ & Not addressed & $\begin{array}{l}\text { Reagan } \\
\text { Bush } \\
\text { Bush } \\
\end{array}$ \\
\hline Second & $\begin{array}{l}\text { Press v. Chem. Inv. Scrvs. } \\
\text { Corp., } 166 \text { F.3d } 529 \text { (1999) }\end{array}$ & $\begin{array}{l}\text { Second Circuit } \\
\text { standard }\end{array}$ & Affirmed dismissal & Fails Lowest & $\begin{array}{l}\text { Nixon } \\
\text { Nixon } \\
\text { Bush } \\
\end{array}$ \\
\hline Second & $\begin{array}{l}\text { Kwalbrun v. Glenayre Tech., } \\
201 \text { F.3d } 431 \text { (1999) } \\
\text { (unpublished) }\end{array}$ & Fails Lowest & $\begin{array}{l}\text { Affirmed } \\
\text { dismissal }\end{array}$ & $\begin{array}{l}\text { Silicon Graphics } \\
\text { standard }\end{array}$ & $\begin{array}{l}\text { Reagan } \\
\text { Clinton } \\
\text { Clinton }\end{array}$ \\
\hline Second & $\begin{array}{l}\text { Novak v. Kasaks, } 216 \text { F.3d } \\
300, \text { cert. denied, } 121 \text { S. Ct. } \\
567(2000)^{*}\end{array}$ & $\begin{array}{l}\text { Second Circuit } \\
\text { standard }\end{array}$ & Reversed dismissal & $\begin{array}{l}\text { Silicon Graphics } \\
\text { standard } 148\end{array}$ & $\begin{array}{l}\text { Bush } \\
\text { Clinton } \\
\text { Clinton }\end{array}$ \\
\hline Second & $\begin{array}{l}\text { Rothman v. Gregor, } 220 \text { F.3d } \\
81(2000)\end{array}$ & $\begin{array}{l}\text { Second Circuit } \\
\text { standard }\end{array}$ & $\begin{array}{l}\text { Reversed dismissal } \\
\text { in part }\end{array}$ & $\begin{array}{l}\text { Second Cireuit } \\
\text { standard }\end{array}$ & $\begin{array}{l}\text { Nixon } \\
\text { Carter } \\
\text { Clinton }\end{array}$ \\
\hline Second & $\begin{array}{l}\text { Ganino v. Citizens Utils. Co., } \\
228 \text { F.3d } 154(2000)\end{array}$ & $\begin{array}{l}\text { Second Circuit } \\
\text { standard }\end{array}$ & Reversed dismissal & Not addressed & $\begin{array}{l}\text { Carter } \\
\text { Carter } \\
\text { Clinton } \\
\end{array}$ \\
\hline Second & $\begin{array}{l}\text { Suez Equity Investors, L.P. v. } \\
\text { Toronto Dominion Bank, } 250 \\
\text { F.3d } 87 \text { (2001) }\end{array}$ & $\begin{array}{l}\text { Second Circuit } \\
\text { standard }\end{array}$ & $\begin{array}{l}\text { Reversed dismissal } \\
\text { in part }\end{array}$ & $\begin{array}{l}\text { Second Circuit } \\
\text { standard }\end{array}$ & $\begin{array}{l}\text { Bush } \\
\text { Reagan } \\
\text { Reagan }\end{array}$ \\
\hline Second & $\begin{array}{l}\text { In re Scholastic Corp. Sec. } \\
\text { Litig., 252 F.3d } 63 \text { (2001) }\end{array}$ & $\begin{array}{l}\text { Second Circuit } \\
\text { standard }\end{array}$ & Reversed dismissal & $\begin{array}{l}\text { Second Circuit } \\
\text { standard }\end{array}$ & $\begin{array}{l}\text { Reagan } \\
\text { Clinton } \\
\text { Ford }\end{array}$ \\
\hline Second & $\begin{array}{l}\text { Kalnit v. Eichler, 264 F.3d } 131 \\
(2001)\end{array}$ & $\begin{array}{l}\text { Second Circuit } \\
\text { standard }\end{array}$ & Affirmed dismissal & $\begin{array}{l}\text { Second Circuit } \\
\text { standard }\end{array}$ & $\begin{array}{l}\text { Carter } \\
\text { Reagan } \\
\text { Clinton }\end{array}$ \\
\hline Third & $\begin{array}{l}\text { In re Advanta Corp. Sec. } \\
\text { Litig., 180 F.3d } 525 \text { (1999)* }\end{array}$ & $\begin{array}{l}\text { Second Circuit } \\
\text { standard }\end{array}$ & Affirmed dismissal & Fails Lowest & $\begin{array}{l}\text { Reagan } \\
\text { Reagan } \\
\text { Reagan }\end{array}$ \\
\hline Third & $\begin{array}{l}\text { Oran v. Stafford, } 226 \text { F.3d } 275 \\
(2000)\end{array}$ & $\begin{array}{l}\text { Second Circuit } \\
\text { standard }\end{array}$ & Affirmed dismissal & $\begin{array}{l}\text { Second Circuit } \\
\text { standard }\end{array}$ & $\begin{array}{l}\text { Reagan } \\
\text { Carter } \\
\text { Bush } \\
\end{array}$ \\
\hline Third & $\begin{array}{l}\text { EP Medsystems, Inc. v. } \\
\text { Echocath, Inc., } 235 \text { F.3d } 865 \\
(2000)\end{array}$ & $\begin{array}{l}\text { Second Circuit } \\
\text { standard }\end{array}$ & $\begin{array}{l}\text { Reversed dismissal } \\
\text { in part }\end{array}$ & Fails Lowest & $\begin{array}{l}\text { Cartet } \\
\text { Bush } \\
\text { Reagan }\end{array}$ \\
\hline Fourth & $\begin{array}{l}\text { Phillips v. LCI Int'l, Inc., } 190 \\
\text { F.3d } 609 \text { (1999) }\end{array}$ & Fails Lowest & Affirmed dismissal & Not addressed & $\begin{array}{l}\text { Reagan } \\
\text { Nixon } \\
\text { Clinton } \\
\end{array}$ \\
\hline Fifth & $\begin{array}{l}\text { Nathenson v. Zonagen, Inc., } \\
267 \text { F.3d } 400(2001)^{*}\end{array}$ & $\begin{array}{l}\text { Intermediate } \\
\text { standard }\end{array}$ & $\begin{array}{l}\text { Reversed dismissal } \\
\text { in part }\end{array}$ & Not available & $\begin{array}{l}\text { Reagan } \\
\text { Bush } \\
\text { Clinton }\end{array}$ \\
\hline Sixth & $\begin{array}{l}\text { In re Comshare, Inc. Sec. } \\
\text { Litig., 183 F.3d } 542(1999)^{*}\end{array}$ & $\begin{array}{l}\text { Intermediate } \\
\text { standard }\end{array}$ & Affirmed dismissal & $\begin{array}{l}\text { Silicon Graphics } \\
\text { standard }\end{array}$ & $\begin{array}{l}\text { Carter } \\
\text { Clinton } \\
\text { Clinton }\end{array}$ \\
\hline
\end{tabular}

148. The Second Circuit opinion in this case characterizes the panel's approach as agreeing with the standard applied by the district court. We find this characterization difficult to square with the district court opinion. 
Table 1

(Continued)

Appellate Interpretations of the "Strong Inference" Standard (As of November 26, 2001)

\begin{tabular}{|c|c|c|c|c|c|}
\hline Ctreult & Decision & $\begin{array}{l}\text { Appellate } \\
\text { Interpretive } \\
\text { Standard }\end{array}$ & Result & $\begin{array}{l}\text { District Court } \\
\text { Interpretive } \\
\text { Standard }\end{array}$ & $\begin{array}{l}\text { Nominating } \\
\text { Presidents }\end{array}$ \\
\hline Sixth & $\begin{array}{l}\text { Helvig v. Vencor, } 210 \mathrm{~F} .3 \mathrm{~d} \\
612(2000) \text {, vacated and } \\
\text { rehearing en banc granted, } \\
222 \text { F.3d } 268 \text { (2000) }\end{array}$ & $\begin{array}{l}\text { Intermediate } \\
\text { standard }\end{array}$ & Afrirmed dismissal & $\begin{array}{l}\text { Pleading } \\
\text { sufficient, } \\
\text { standard not } \\
\text { explained }\end{array}$ & $\begin{array}{l}\text { Carter } \\
\text { Bush } \\
\text { Dissent: } \\
\text { Carter }\end{array}$ \\
\hline Sixth & $\begin{array}{l}\text { Helvig v. Vencor, } 251 \text { F.3d } \\
540 \text { (2001) (en bane) }\end{array}$ & $\begin{array}{l}\text { Intermediate } \\
\text { standard }\end{array}$ & Reversed dismissal & $\begin{array}{l}\text { Pleading } \\
\text { sufficient, } \\
\text { standard not } \\
\text { explained }\end{array}$ & $\begin{array}{l}\text { Carter (x2) } \\
\text { Clinton (x5) } \\
\text { Dissent: } \\
\text { Carter } \\
\text { Reagan } \\
\text { Bush (x4) }\end{array}$ \\
\hline Eighth & $\begin{array}{l}\text { Florida State Bd. of Admin. v. } \\
\text { Green Tree Fin. Corp., } 270 \\
\text { F.3d } 645 \text { (2001) }\end{array}$ & $\begin{array}{l}\text { Second Circuit } \\
\text { standard }\end{array}$ & Reversed dismissal & Fails Lowest & $\begin{array}{l}\text { Carter } \\
\text { Reagan } \\
\text { Clinton }\end{array}$ \\
\hline Ninth & $\begin{array}{l}\text { In re Silicon Graphics Inc. } \\
\text { Sec. Litig., 183 F.3d } 970 \\
(1999)^{*}\end{array}$ & $\begin{array}{l}\text { Silicon Graphics } \\
\text { standard }\end{array}$ & Affirmed dismissal & $\begin{array}{l}\text { Silicon Graphics } \\
\text { standard }\end{array}$ & $\begin{array}{l}\text { Nixon } \\
\text { Reagan } \\
\text { Dissent: } \\
\text { Kennedy }\end{array}$ \\
\hline Ninth & $\begin{array}{l}\text { Heliotrope Gan, Inc. v. Ford } \\
\text { Motor Co., } 189 \text { F.3d } 971 \\
\text { (1999) }\end{array}$ & $\begin{array}{l}\text { Silicon Graphics } \\
\text { standard }\end{array}$ & Affïrmed dismissal & Unclear & $\begin{array}{l}\text { Bush } \\
\text { Bush } \\
\text { Reagan }\end{array}$ \\
\hline Ninth & $\begin{array}{l}\text { Yourish v. Cal. Amplifier, } 191 \\
\text { F.3d } 983 \text { (1999) }\end{array}$ & $\begin{array}{l}\text { Silicon Graphics } \\
\text { standard }\end{array}$ & Affirmed dismissal & $\begin{array}{l}\text { Fails Fed. R. Civ. } \\
\text { P.9(b) }\end{array}$ & $\begin{array}{l}\text { Reagan } \\
\text { Bush } \\
\text { Clinton }\end{array}$ \\
\hline Ninth & $\begin{array}{l}\text { Marlisman Partners, L.P. v. } \\
\text { Chantal Pharmaceutical Corp., } \\
\text { 234 F.3d 1277 (2000) } \\
\text { (unpublished) }\end{array}$ & $\begin{array}{l}\text { Silicon Graphics } \\
\text { standard }\end{array}$ & Affirmed dismissal & $\begin{array}{l}\text { Second Circuit } \\
\text { standard }\end{array}$ & $\begin{array}{l}\text { Reagan } \\
\text { Bush } \\
\text { Clinton }\end{array}$ \\
\hline Ninth & $\begin{array}{l}\text { Desaigoudar v. Mejercord, } \\
223 \mathrm{~F} .3 \mathrm{~d} 1020 \text { (2000), cent. } \\
\text { denied, } 121 \mathrm{~S} \text {. Ct. } 1962 \text { (2001) }\end{array}$ & $\begin{array}{l}\text { Silicon Graphics } \\
\text { standard }\end{array}$ & Affirmed dismissal & Unclear & $\begin{array}{l}\text { Nixon } \\
\text { Carter } \\
\text { Clinton }\end{array}$ \\
\hline Ninth & $\begin{array}{l}\text { Howard v. Everex Sys., Inc., } \\
228 \text { F.3d } 1057(2000)\end{array}$ & $\begin{array}{l}\text { Second Circuit } \\
\text { standard }\end{array}$ & $\begin{array}{l}\text { Reversed summary } \\
\text { judgment in part }\end{array}$ & Unclear & $\begin{array}{l}\text { Nixon } \\
\text { Carter } \\
\text { Clinton }\end{array}$ \\
\hline Ninth & $\begin{array}{l}\text { Lawrence v. Zilog, Inc., } 242 \\
\text { F.3d } 382 \text { (2000) (unpublished) }\end{array}$ & $\begin{array}{l}\text { Silicon Graphics } \\
\text { standard }\end{array}$ & Affirmed dismissal & Fails Lowest & $\begin{array}{l}\text { Reagan } \\
\text { Bush } \\
\text { Clinton }\end{array}$ \\
\hline Ninth & $\begin{array}{l}\text { Zcid v. Kimberley, } 2001 \text { WL } \\
357526 \text { (2001) (unpublished) }\end{array}$ & $\begin{array}{l}\text { Stlicon Graphics } \\
\text { standard }\end{array}$ & Affirmed dismissal & $\begin{array}{l}\text { Silicon Graphics } \\
\text { standard }\end{array}$ & $\begin{array}{l}\text { Carter } \\
\text { Bush } \\
\text { Clinton }\end{array}$ \\
\hline Ninth & $\begin{array}{l}\text { Ronconi v. Larkin, } 253 \text { F.3d } \\
423 \text { (2001) }\end{array}$ & $\begin{array}{l}\text { Silicon Graphics } \\
\text { standard }\end{array}$ & Affirmed dismissal & Fails Lowest & $\begin{array}{l}\text { Kennedy } \\
\text { Bush } \\
\text { Bush }\end{array}$ \\
\hline Ninth & $\begin{array}{l}\text { Berger v. Ludwiek, 2001 WL } \\
86 \$ 355 \text { (2001) (unpublished) }\end{array}$ & $\begin{array}{l}\text { Silicon Graphics } \\
\text { Standard }\end{array}$ & Affirmed dismissal & $\begin{array}{l}\text { Silicon Graphics } \\
\text { standard }\end{array}$ & $\begin{array}{l}\text { Carter } \\
\text { Clinton } \\
\text { Clinton }\end{array}$ \\
\hline Tenth & $\begin{array}{l}\text { Sheldon v. Vermonty, } 246 \\
\text { F.3d 6\$2 (2000) (unpublished) }\end{array}$ & Unclear & Reversed dismissal & Fails Lowest & $\begin{array}{l}\text { Reagan } \\
\text { Reagan } \\
\text { Clinton }\end{array}$ \\
\hline Tenth & $\begin{array}{l}\text { City of Philadelphia v. } \\
\text { Fleming Cos, Inc., } 264 \text { F.3d } \\
1245 \text { (2001)* }\end{array}$ & $\begin{array}{l}\text { Intermediate } \\
\text { standard }\end{array}$ & Affirmed dismissal & $\begin{array}{l}\text { Silicon Graphics } \\
\text { standard }\end{array}$ & $\begin{array}{l}\text { Reagan } \\
\text { Carter } \\
\text { Carter } \\
\end{array}$ \\
\hline Elerenth & $\begin{array}{l}\text { Bryant v. Avado Brands, Inc., } \\
\text { 187 F.3d } 1271 \text { (1999)* }\end{array}$ & $\begin{array}{l}\text { Intermediate } \\
\text { standard }\end{array}$ & $\begin{array}{l}\text { Vacated denial of } \\
\text { motion to dismiss }\end{array}$ & $\begin{array}{l}\text { Second Circuit } \\
\text { standard }\end{array}$ & $\begin{array}{l}\text { Carter } \\
\text { Ford } \\
\text { Dissent: } \\
\text { Carter }\end{array}$ \\
\hline Eleventh & $\begin{array}{l}\text { Theoharous v. Fong. } 256 \text { F.3d } \\
1219 \text { (2001) }\end{array}$ & $\begin{array}{l}\text { Intermediate } \\
\text { standard }\end{array}$ & Affĭmed dismissal & $\begin{array}{l}\text { Intermediate } \\
\text { standard }\end{array}$ & $\begin{array}{l}\text { Reagan } \\
\text { Ford } \\
\text { Carter }\end{array}$ \\
\hline
\end{tabular}


We analyzed each of these thirty-three decisions to ascertain the interpretive standard applied by each appellate court, the result of its ruling, and the standard applied by the district court. We also identified the president who nominated each of the judges who participated in these rulings.

Analysis of the decisions revealed four distinct interpretive styles:

1. Fails Lowest. Here, the court concludes that interpretation of the "strong inference" standard is unnecessary because the complaint fails even the weakest interpretation of the pleading standard, or fails Rule 9(b) pleading standards.

2. Second Circuit standard. The court rules that pleading motive and opportunity suffices to establish a strong inference.

3. Intermediate standard. The court rules that pleading motive and opportunity will not suffice, but plaintiffs may plead facts sufficient to support a strong inference of recklessness. This standard is also often called the "Baesa standard."149

4. Silicon Graphics standard. The court rules that motive and opportunity do not suffice, and plaintiffs must plead facts sufficient to support a strong inference of deliberate recklessness or fraudulent intent. This standard was first articulated in the Silicon Graphics litigation. 150

In addition, there is a fifth possible interpretive style that we describe as "Satisfies Highest." Here, the court concludes that the complaint is so well crafted that it satisfies the most stringent interpretation of the strong pleading standard without ever defining that articulation. This style arises frequently in our later analysis of the district court database, but does not appear in our analysis of appellate rulings or in our analysis of lower court rulings giving rise to these appellate cases. ${ }^{151}$

\section{B. Inconsistent Appellate Interpretations}

Table 1 documents that appellate courts have adopted three distinct interpretations of the "strong inference" provision, 152 and have avoided the issue once, notwithstanding Congress' stated goal of uniformity. ${ }^{153}$ The

149. In re Baesa Sec. Litig., 969 F. Supp. 238 (S.D.N.Y. 1997).

150. In re Silicon Graphics Inc. Sec. Litig., No. C96-0393, 1997 WL 337580 (N.D. Cal. June 5, 1997), aff'd, 183 F.3d 970 (9th Cir. 1999). The district court's interim orders are reported at 970 F. Supp. 746 (N.D. Cal. 1997) and 1996 WL 664639 (N.D. Cal. Sept. 25, 1996).

151. See infra p. 684.

152. Accord Eth \& Drosman, supra note 20, at 160-61 (citing the three-way split and observing that "[t]he sharp division among the courts of appeals has, indeed, led to an increase in litigation over the proper venue for securities class actions").

153. The Statement of Managers from the Reform Act explains Congress' concern that 
Second, Third, and Eighth Circuits have construed the Act as adopting the Second Circuit's "motive and opportunity" standard. This standard is generally viewed as the weakest or most pro-plaintiff interpretation of the "strong inference" provision. The First, Fifth, Sixth, Tenth, and Eleventh Circuits have held that motive and opportunity do not necessarily suffice to create the requisite strong inference of scienter. All of these courts except for the Eleventh, however, have held that motive and opportunity can be used as factors to be considered in evaluating circumstantial evidence of a conscious or reckless misstatement.154 We describe these holdings as articulating an "Intermediate standard" because they fall between the Second Circuit's relatively lax interpretation and the Ninth Circuit's more stringent approach. Finally, the Ninth Circuit in Silicon Graphics requires that plaintiffs plead that the defendants knew that the statements were false, or that the defendants were "consciously" or "deliberately" reckless in disregarding the truth or falsity of the statements. The Ninth Circuit expressly rejected pleading the basis of motive and opportunity.

The congressional effort to create ambiguity thus appears to have succeeded at the appellate level. Nine different courts of appeal, applying identical rules of statutory construction to identical text and legislative history, have reached three distinct interpretations of the "strong inference" standard. One other circuit, the Fourth, has avoided the question despite having had a clear opportunity to address it.

If there is any discernable trend in the appellate decisions, it is toward the Intermediate standard. From a perspective that emphasizes the formal canons of construction, this may seem a somewhat surprising result. As we explained in Part III, the "strong inference" language has an antecedent in the Second Circuit case law interpreting Rule 9(b). The canon of construction that statutes are to be interpreted consistently with prior judicial decisions supports adopting the Second Circuit standard if a court chooses to ignore the conflicted legislative history. The legislative history, however, more strongly seems to support the Silicon Graphics standard. The conference committee report's explanation for the deletion of the Specter amendment, which would have codified the two Second Circuit tests, suggests that Congress was satisfied with neither prong. The Intermediate standard rejects the motive and opportunity test deriving from explanatory language of footnote number twenty-three of the Conference Report, but that footnote also implies that recklessness has been

the courts of appeals had “interpreted Rule 9(b)'s requirement in conflicting ways." 141 CONG. REC. H13,702 (1995). The Statement of Managers also notes that congressional hearings had "included testimony on the need to establish uniform and more stringent pleading requirements." Id.

154. The Eleventh Circuit's disagreement on this point might be construed as creating a fourth standard. As the Eleventh Circuit is not entirely clear on this point, we have categorized it as following the Intermediate standard. 
eliminated, a step that courts adopting the Intermediate standard have declined to take. Put another way, the most common appellate interpretation is the least defensible as an analytic matter of statutory construction.

The Intermediate standard is, however, the most understandable as a matter of judicial compromise if the courts really believe that the record is hopelessly confused. In the face of uncertainty, the middle ground, an "average" of the two most analytically defensible interpretations, may appear to be the safest. The Intermediate standard may also make the most sense if the appellate courts seek to maximize the judiciary's flexibility, consistent with our hypothesis that courts value the discretion conferred by ambiguity. The Intermediate standard is in many ways the most ambiguous, giving courts wide latitude in determining whether to dismiss or not based on a given set of facts.

The confusion at the appellate level is actually more profound than these data suggest. In particular, the Second Circuit's own post-Reform Act decisions underscore the ambiguity inherent in its articulation of the "strong inference" standard. In Press, a Second Circuit panel concluded that the Reform Act adopted the Second Circuit standard, but that "[t]he Second Circuit has been lenient in allowing scienter issues to withstand summary judgment based on fairly tenuous inferences."155 Indeed, the panel in Press held that the "strong inference" standard was satisfied despite finding that the underlying misstatement was immaterial156 - a rather non-intuitive and contestable implementation of a heightened pleading standard.

In Novak, however, a different panel of the Second Circuit sought to minimize the Press court's observations with regard to the "strong inference" standard by labeling them "dicta," 157 despite the fact that other courts have viewed the same language as a "holding."158 Novak also articulated a stricter formulation of the "strong inference" standard than Press, stating that it was taking a "middle ground" between the Third Circuit's wholesale adoption of the prior Second Circuit standard and the decisions of other courts that reject "motive and opportunity." 59 Novak explained that courts "need not be wedded to [motive and opportunity] in articulating the prevailing standard," and went on to emphasize several limits on the ability to plead motive and opportunity. ${ }^{160}$ Novak also commented that the district court's requirement that

155. Press v. Chem. Inv. Servs. Corp., 166 F.3d 529, 538 (2d Cir. 1999).

156. Id. at 538-39.

157. Novak v. Kasaks, 216 F.3d 300, 310 (2d Cir.), cert. denied, 121 S. Ct. 567 (2000).

158. See, e.g., Coates v. Heartland Wireless Comm., Inc., 100 F. Supp. 2d 417, 431

(N.D. Tex. 2000); T.H.C., Inc. v. Fortune Petroleum Corp., No. 96CIV.2690, 1999 WL 182593, at *2 (S.D.N.Y. Mar. 31, 1999).

159. Novak, 216 F.3d at 310 .

160. Id. In this regard, the Eighth Circuit's interpretation in Green Tree of the Second Circuit standard also puts limits on the use of the motive and opportunity standard. See Florida State Bd. of Admin. v. Green Tree Fin. Corp., 270 F.3d 645 (2001). 
plaintiffs plead "conscious recklessness" "was an accurate statement of the law."161

The Novak court's suggestion that the Second Circuit would apply the motive and opportunity standard more rigorously has not, however, been followed by subsequent Second Circuit panels. Rothman quotes Novak for the proposition that the Reform Act did not change the standard for pleading scienter in the Second Circuit, ignoring the limits that Novak appeared to impose on motive and opportunity pleading, as well as the Novak court's invocation of "conscious recklessness."162 Ganino fails to even cite Novak. It relies instead on pre-Reform Act precedent and treats the question of whether motive and opportunity suffices as a basis for pleading scienter as one of first impression. ${ }^{163}$ As a result, instead of strengthening the Second Circuit's "strong inference" standard as Novak apparently intended, the Rothman and Ganino decisions actually echo the weaker forms of the "strong inference" standard applied by the Second Circuit prior to the enactment of the Reform Act.

Commentators who have studied the Second Circuit's post-Reform Act applications thus have concluded that the decisions in Rothman and Ganino, which followed within months of Novak, undermine Novak's suggestion of a potentially more stringent definition of the motive and opportunity standard.164 Indeed, the Second Circuit reversed dismissals in each of the four cases to reach it post-Novak, a pattern more consistent with a weaker standard than with a stronger one. On the other hand, the Second Circuit's most recent case in our sample, Kalnit, is more demanding in applying the motive and opportunity standard and rejects generalized allegations of motive. ${ }^{165}$ In sum, there appears to be material disagreement within the Second Circuit itself as to the proper interpretation and application of the Second Circuit's own standard.

The appellate decisions reveal an additional level of tension with regard to the implications of the "strong inference" standard for the resolution of motions for summary judgment. In Everex, a Ninth Circuit panel held that the weaker Second Circuit standard would apply to the resolution of a motion for summary judgment, and distinguished Silicon Graphics on the ground that it involved a motion to dismiss, not a summary judgment motion.166 Although this distinction is faithful to the text of the statute, it creates the unusual result that standards for pleading a complaint, which must be done without discovery, are

161. Novak, 216 F.3d at 309.

162. Rothman v. Gregor, 220 F.3d 81, 90 (2d Cir. 2000).

163. Ganino v. Citizens Utils. Co., 228 F.3d 154, 168-70 (2d Cir. 2000).

164. See Dennis J. Block \& Jonathan M. Hoff, Second Circuit Developments Under the PSLRA, N.Y.L.J., Feb. 22, 2001, at 5.

165. Kalnit v. Eichler, 264 F.3d 131, 140 (2d Cir. 2001).

166. Howard v. Everex Sys., Inc., 228 F.3d 1057 (9th Cir. 2000). 
higher than standards for summary judgment, at which point the plaintiff will have had the benefit of discovery. This result was rejected by the First Circuit in Geffon, 167 thus creating a split between circuits as to the standard for demonstrating scienter at the summary judgment stage in addition to the split over the proper standard at the pleading stage.

Despite this diversity in the interpretation of the pleading standard among and within the circuits, the appellate courts have shown a surprisingly strong trend in the outcome of decisions applying the standard: Of the thirty-three appellate decisions to date, only eleven have resulted in a victory for the plaintiff. To some extent, this observation may reflect a sample bias. Defendants who have lost on a motion to dismiss ordinarily cannot take an immediate appeal absent certification by the district court. ${ }^{168}$ If the defendants' motion is granted with prejudice, however, plaintiffs are entitled to an immediate appeal as of right. The sample of cases decided on appeal may thus be composed of fact patterns that present the strongest arguments for dismissal because of self-selection by plaintiffs and defendants. Even so, the overwhelming majority of plaintiff victories on appeal (nine out of eleven) have come from circuits applying the Second Circuit's motive and opportunity standard, the most pro-plaintiff interpretation of the law. The other two plaintiff victories have come from courts applying the Intermediate standard; no panel has reversed a dismissal applying the Silicon Graphics standard. This pattern is consistent with the hypothesis that the standard does influence the outcome, and that plaintiffs do in fact fare better on appeal in circuits that apply the Second Circuit standard rather than one of the more rigorous formulations.

The data also suggest, however, that the Second Circuit standard is not easily applied in a consistent manner. In six cases, appellate panels applied the Second Circuit standard to overturn district court dismissals where the district court also had applied the Second Circuit standard or had concluded that the complaint failed the lowest standard. This pattern of reversals can arise only if judges disagree on the proper application of the Second Circuit standard to a fixed set of facts, or on the actual meaning of the Second Circuit standard, even though they agree that the Second Circuit standard is the correct interpretation of the "strong inference" provision.

The Intermediate standard is also subject to dispute over its application. The Sixth and Eleventh Circuits are both generally viewed as falling in the "Intermediate standard" camp, but when the Sixth Circuit reversed a panel's dismissal in Helwig, the en banc court rejected as "unduly rigid" the Eleventh Circuit's reading of the Sixth Circuit's Comshare opinion as categorically excluding pleading motive and opportunity. 169 According to the en banc court,

167. Geffon v. Micrion Corp., 249 F.3d 29 (1st Cir. 2001).

168. 28 U.S.C. $\S 1292$.

169. Helwig v. Vencor, 251 F.3d 540, 550 (6th Cir. 2001) (en banc) (citing Bryant v. 
"conclusory labels" of motive and opportunity would not be sufficient to plead a complaint adequately, but facts showing motive and opportunity "can be catalysts to fraud and so serve as external markers to the required state of mind," which would be sufficient. 170 The majority's use of motive and opportunity provoked a dissent from the author of the vacated panel opinion, charging that the stock sales alleged by the plaintiffs as a motive did not satisfy the "strong inference" standard because they were not alleged to have been unusual in scope or timing. ${ }^{171}$

\section{Political Patterns}

The political composition of the judges of the en banc court in Helwig and their voting pattern on the issue were at least as notable as the disagreement over the application of the Intermediate standard. While the authors of both the majority and dissenting opinions were Carter appointees, the judges in the majority had all been appointed by Democratic presidents, and the other dissenting judges had all been appointed by Republican presidents.

This breakdown along party lines suggests that worldviews and political affiliations may be correlated with interpretations and outcomes under this statute. Putting Helwig to one side, Democratic and Republican nominees are equally represented (fifteen and fifteen) in the cases reversing dismissal. However, Republicans outnumber Democrats (thirty-six to twenty-five, with two Democratic appointees dissenting) in cases affirming dismissals. A similar partisan split may be in evidence in Silicon Graphics. There, the plaintiff/appellant sought a rehearing en banc, which was denied. The five judges who dissented from that denial were all Democratic appointees. ${ }^{172}$

While these observations may be viewed by some as consistent with the hypothesis that political affiliation is correlated with judicial behavior at the appellate level, 173 we urge caution before reaching such a conclusion. Our sample size at the appellate level is small and there is no strong ideological split in the precedent-setting opinions: Six Democratic appointees have voted for the Second Circuit standard, as have five Republican; eight Democratic appointees have voted for the Intermediate standard, as compared to six Republican; and one Democrat has dissented from the Silicon Graphics

Avado Brands, Inc., 187 F.3d 1271, 1287 (11th Cir. 1999)).

170. Id. at 550 .

171. Id. at 572-73 (Kennedy, J., dissenting) (rejecting also allegations that certain statements alleged in the pleading raised a strong inference of scienter).

172. In re Silicon Graphics Inc. Sec. Litig., 195 F.3d 521 (9th Cir. 1999) (Reinhardt, J., dissenting).

173. For additional discussion of this hypothesis, see infra notes 201-206 and accompanying text. 
standard, while two Republicans have voted for that standard. Moreover, as described in greater detail in the Appendix, the district court data only weakly support a party affiliation hypothesis.

\section{Patterns in the Decisions to Seek or Avoid Supreme Court Review}

Given the frequency with which plaintiffs are losing on appeal, it is somewhat surprising that plaintiffs have filed a petition for certiorari in only one of the twenty-two appellate decisions that have gone against them. ${ }^{174}$ They have declined the opportunity to file petitions despite the fact that several of these decisions, particularly Silicon Graphics, have interpreted the "strong inference" standard in ways that provoked heated disagreements from the plaintiffs' bar. Indeed, Silicon Graphics presented a pure question of law with a clear circuit split, making it an ideal vehicle for Supreme Court review.

Why has the plaintiffs' bar not sought vindication for its views before the Supreme Court? We conjecture that plaintiffs' attorneys do not expect that the Supreme Court, as currently configured, will adopt a pro-plaintiff interpretation of the "strong inference" standard. The apparent strategy is to keep the issue away from the Court for as long as possible because the plaintiffs' bar prefers to tolerate a mixed set of decisions at the circuit level rather than risk a uniform, but negative, interpretation from the Supreme Court. Worse yet from the perspective of the plaintiffs' bar, the Supreme Court could finally confront the question of the status of recklessness under Section 10(b), an issue as to which the Court has twice before expressly reserved its views, ${ }^{175}$ and conclude that, given the implied nature of the private right giving rise to the cause of action, the cause of action should be narrowly construed to exclude recklessness from the definition of scienter. The plaintiffs' bar may well have real concerns that a holding that Section 10(b)'s requirement of scienter is not satisfied by recklessness would harm their interests even more than an adverse ruling with regard to the interpretation of the heightened pleading standard.

The reluctance of the plaintiffs' bar to petition for certiorari, coupled with the Court's traditional wariness of resolving disputed legal questions before they are fully aired by the circuit courts, has interesting implications for the empirical analysis of debate over the "strong inference" standard. The divergence of opinions among the circuits has allowed for a natural experiment allowing stock market participants to register their view of the wealth effects associated with resolution of this dispute. The Ninth Circuit's demanding

174. See Desaigoudar v. Meyercord, 223 F.3d 1020 (2000), cert. denied, 121 S. Ct. 1962 (2001). Defendants petitioned for certiorari in Novak, but that petition was denied. 121 S. Ct. 567 (2001). Defendants have also petitioned for certiorari in Scholastic, and that petition is still pending.

175. See supra note 77. 
interpretation of the standard in Silicon Graphics was received favorably in the stock market as the decision resulted in positive abnormal returns for shareholders of a sample of high-technology firms, the industry most vulnerable to such suits. 176 That positive stock price response was most favorable for firms most likely to be targeted for non-meritorious suits, and least favorable (albeit still positive) for firms most likely to commit fraud. In the absence of a more determinate answer from the traditional tools of statutory interpretation, the Supreme Court could rely on these findings to invoke a functionalist, wealth-promoting interpretive approach and adopt the Ninth Circuit's interpretation of the standard. 177

In sum, the appellate data are consistent with the following hypotheses:

(1) Congress successfully obscured the meaning of the "strong inference" standard. It generated three distinct schools of interpretation among the circuits, and induced one court to avoid the issue altogether.

(2) The trend in appellate decisions is toward the Intermediate standard, rejecting the motive and opportunity test, but preserving recklessness.

(3) The "strong inference" standard is sufficiently ambiguous to allow a material split within the Second Circuit itself as to the application of the standard that the circuit itself originated. Moreover, appellate courts and district courts applying the same standard to the same set of facts regularly reach inconsistent conclusions as to whether motions to dismiss should be granted.

(4) The interpretive standard chosen at the appellate level influences the outcomes of the decision.

(5) The plaintiffs' bar fears an unfavorable interpretation of the "strong inference" standard by the Supreme Court. It may also fear a Supreme Court ruling on the adequacy of recklessness as a basis for scienter under Section 10(b).

(6) The Ninth Circuit's interpretation of the "strong inference" standard, which is the most pro-defendant, was favorably received by investors.

(7) Judges nominated by Republican presidents tend to adopt a more prodefendant stance, while judges nominated by Democratic presidents tend to adopt a more pro-plaintiff stance, although the pattern is not entirely consistent.

176. See Marilyn F. Johnson, Karen K. Nelson \& A.C. Pritchard, In re Silicon Graphics Inc.: Shareholder Wealth Effects Resulting from the Interpretation of the Private Securities Litigation Reform Act's Pleading Standard, 73 S. CAL. L. REV. 773 (2000).

177. William N. Eskridge, Jr., Dynamic Statutory Interpretation, 135 U. PA. L. REV. 1479 (1987). It is a logical possibility that adoption of the Intermediate standard might have been met with an even greater positive abnormal return. We can suggest, however, that the Silicon Graphics standard was preferred by investors to the baseline, expected case (the Second Circuit standard). 


\section{CONCLUSION}

There is a clear victor in the contest between the legislative ability to obscure and the judicial capacity consistently to interpret the "strong inference" provision of the Private Securities Litigation Reform Act of 1995. The legislative ability to obscure thrashes the judicial capacity to interpret.

At the appellate level, the circuits are split into three distinct camps. The Second, Third, and Eighth Circuits conclude that the "strong inference" provision incorporates the Second Circuit standard. The First, Fifth, Sixth, Tenth, and Eleventh Circuits reject the Second Circuit standard and conclude that Congress intended to adopt a stricter Intermediate standard. The Ninth Circuit adopts the even more rigorous "Silicon Graphics" interpretation. This three-way split is compounded by evidence of inconsistent interpretations among panels within the same circuit, inconsistent applications of a common standard to a common set of facts, and the emergence of a new split as to whether the "strong inference" standard applies only on motions to dismiss or whether it also applies on motions for summary judgment.

The situation is at least as confused at the district court level. The analysis of 167 district court rulings presented in the Appendix indicates that judges who are unconstrained by appellate precedent frequently adopt minimalist strategies that avoid the need to interpret the statute. They rule either that a complaint is sufficiently strong that it satisfies the most stringent conceivable articulation of the pleading standard, or that it is so deficient that it fails the most forgiving articulation, without explaining how the "strong inference" standard is to be interpreted or applied.

District court judges who interpret the "strong inference" provision generate aggregate patterns of behavior that are, to a remarkable degree, statistically indistinguishable from a "coin-toss" model of judicial behavior. In this coin-toss model, the judge first flips a coin to determine whether the Second Circuit standard prevails or whether Congress intended to adopt a more stringent standard. If a more stringent standard applies then the judge tosses the coin again to decide between the Intermediate standard and the Ninth Circuit standard. While we do not mean to imply that judges actually flip coins to decide the question, we do observe that the aggregate data do not allow us to reject the hypothesis that many coins are being flipped as judges interpret the "strong inference" provision in the absence of controlling circuit precedent.

The data are mixed as to whether the articulation of an interpretive standard has a statistically significant effect on the outcome of the underlying motion to dismiss. At the appellate level, the adoption of the Second Circuit standard appears to be correlated with resolutions that are more favorable to plaintiffs. The appellate data also suggest, however, that trial court judges and appellate judges frequently differ on the proper application of the same standard to a fixed set of facts. At the district court level, we find a statistically 
significant correlation between the selection of an interpretive standard and the resolution of the underlying motion to dismiss, but also find that other factors, such as docket load, judicial experience with class action securities fraud litigation, and the intensity of litigation within the district involving technology issuers, can play a significant role in explaining both the selection of the interpretive standard and the resolution of the underlying motion.

These findings imply that judges retain significant discretion in the application of law to facts when resolving motions to dismiss securities fraud complaints. The level of discretion is sufficiently great that judges frequently can dispose of motions in a manner they deem most appropriate without being overly constrained by the formal definition of the standard. Put another way, even if the courts were all promptly to coalesce on a single interpretation of the "strong inference" standard, it does not necessarily follow that there would be uniformity in the resolution of the underlying motions to dismiss. We again caution that this observation should not be overinterpreted, and we do not suggest that the articulation of an interpretive standard is irrelevant. Instead, we interpret the data as suggesting that if the courts were consistently to adopt the Ninth Circuit's (Second Circuit's) standard, the probability of prodefendant (pro-plaintiff) resolutions would increase, but courts would nonetheless retain significant discretion when applying the standard to any given set of facts.

This observation suggests that the question of statutory interpretation is most precisely analyzed at two distinct levels: a formal, semantic level and an applied, practical level. If a statute gives rise to a series of consistent, formal judicial interpretations, the variance in the judicial application of the standard to facts typically at issue in the litigation nonetheless may be sufficiently large that the legislature succeeds in achieving random outcomes even though the courts appear to be linguistically precise in the articulation of a common legal standard. This result facilitates legislative compromise, but it also suggests that the goal of consistency in statutory interpretation can be significantly more difficult to accomplish than simple textual analysis of judicial holdings would indicate.

The data also display patterns that inform our understanding of class action securities fraud litigation. The district court data contain a cluster of correlated variables that includes presence in the Northern District of California, the intensity of class action securities fraud litigation in the district, and the intensity of litigation against technology issuers in the district. Variables in this cluster are correlated with pro-defendant interpretations of the "strong inference" standard as well as with pro-defendant rulings on the underlying motions to dismiss.

The data also indicate that district court judges with more than one decision in our database are more likely to rule in favor of defendants on motions to dismiss. The same judges do not, however, display an equivalently strong 
tendency to adopt pro-defendant interpretations of the pleading standard.

This behavioral pattern could result either because judges who are frequently exposed to securities fraud litigation learn to be skeptical of plaintiffs' claims on the merits (the "familiarity breeds skepticism" hypothesis), or because these judges have an incentive based on judicial economy to clear their dockets of frequently arising claims (the "docket control" hypothesis). We view the data as more consistent with the "familiarity breeds skepticism" hypothesis because variables that measure the intensity and frequency of securities fraud litigation and litigation against technology issuers are systematically and meaningfully significant, unlike other variables designed to measure for general docket-control incentives. Further, judges who are interested in economizing on resources might often be better served by issuing pro-plaintiff rulings that could quickly drive the litigation toward a settlement. These pro-plaintiff strategies could consume fewer judicial resources in comparison with the judicial effort required to write complex pro-defendant opinions on motions to dismiss that might only serve to prolong judicial involvement at the trial and appellate levels.

Other variables are sporadically significant in our analysis, but none tell as compelling or comprehensive a story. The identity or political affiliation of the president who nominated a district court judge is occasionally significant. Judges nominated by Democratic presidents tend to display pro-plaintiff tendencies, but this pattern is hardly uniform or pervasive in the data. At the appellate level, there also appears to be a weak tendency on the part of judges nominated by Democratic presidents to adopt more pro-plaintiff interpretations. We do not, however, view these patterns as sufficient to support a strong conclusion that political inclinations are here systematically correlated with judicial behavior. The data are, at most, suggestive.

Presence in the Northern District of Illinois or in the Southern District of New York is correlated with pro-plaintiff rulings. These tendencies appear to reflect judicial perspectives that are not systematically related to any other significant variables measured in our analysis. If those court-specific variables were more consistently significant in a larger number of regressions, we would suggest that plaintiffs have an unexplained advantage in those two districts. The data are not, however, strong enough in our view to support that conclusion.

We also find that judges with backgrounds as prosecutors tend toward prodefendant interpretations of the statute. This finding is contrary to our initial expectation that judges with prosecutorial backgrounds would tend to give credence to plaintiffs' allegations of fraud. Again, given the large number of regressions we have run and variables we have tested, we caution against overinterpretation of this finding.

What are the implications of these results? At the narrowest level, they suggest that the questions presented by the "strong inference" debate are ripe 
for Supreme Court review in order to resolve a split among the circuits and confusion in the district courts. A Supreme Court decision could establish a consistent nationwide interpretation of the "strong inference" standard, but we are not confident that any such standard would generate a consistent set of results on the resolution of motions to dismiss. Again, this is not to suggest that a Supreme Court decision interpreting the "strong inference" standard would have no effect on the resolution of the underlying motions. The implication of our findings is, instead, that it is easy to exaggerate the degree of consistency likely to result from any such ruling.

More broadly, however, our findings can inform the larger controversy over methods of statutory construction and the analysis of the strategic interaction between the legislative and judicial branches. Recall our earlier observation that legislators seeking compromise will rationally prefer ambiguity in the interpretation of statutory language. Without such ambiguity, legislators operating in a rational expectations equilibrium would be unable to implement mixed-game strategies as part of the legislative process, and legislators with conflicting views would be unable simultaneously to claim victory over the same legislative language. Ambiguity is thus a valuable lubricant in the legislative process. 178

Judges can also value ambiguity to the extent that it allows them greater latitude to exercise discretion, more room within which to compromise with colleagues, and increased opportunity to avoid resolutions that they view as unjust or incorrect by whatever metric they might apply. Judge Posner, for example, suggests that judges often vote "their policy preferences and personal convictions," within the confines of the "rules" of judging, as part of the judging "game."179 Judges express these preferences particularly when "cases cannot be decided by reasoning from conventional legal materials. Such cases require a judge to exercise a legislative judgment, although a more confined one than real legislators are authorized to exercise." 180 Statutory language that is successfully ambiguous cannot, by construction, be "decided by reasoning from conventional legal materials." It follows that to the extent that judges value their ability to vote "policy preferences and personal convictions" as part of the "game" of judging, judges should also support a technology of interpretation that is not unduly constricting and that permits a material, principled degree of dispute over the pragmatic meaning of words..$^{181}$ The

178. See supra Part II.

179. POSNER, supra note 9, at 131. See generally supra Part II.

180. Id. (internal quotation marks omitted).

181. Much in the same vein, Judge Posner has observed that

[t]he interpretation of texts is not a logical exercise, and the bounds of "interpretation" are so elastic ... as to cast the utility of the concept into doubt.... [P]ragmatists will ask which of the possible resolutions has the best consequences, all things that lawyers are or should be interested in considered, including the importance of preserving language as a medium of 
Supreme Court's elastic presumptions for the use of legislative history in statutory interpretation are, we believe, an example of this flexible interpretive technology. A side effect of this flexible approach is that, while maintaining discretion for the high court, it reduces the ability to ensure consistent interpretation by lower courts.

To the extent that the legislative and judicial branches share a de facto preference for some level of ambiguity, it follows that careful efforts to craft and rigorously apply consistent principles of statutory interpretation-or to invent novel rules of interpretation that foster greater consistency-are doomed to failure if they impart too much precision. These efforts are doomed not because they are lacking in any formal or intellectual sense, although some scholars might make that argument.182 Instead, efforts at precision in statutory interpretation may be naturally limited by the joint preference of the legislative and judicial branches for a level of ambiguity that allows each branch to go about its business as it best sees fit. The broadest implication of this view is that much of the debate over statutory construction may be intellectually interesting but pragmatically irrelevant because theories of interpretation that seek a level of consistency that is valued by neither the legislature nor the courts would never be implemented in an equilibrium relationship between the branches. ${ }^{183}$

The suggestion that the legislative and judicial branches value ambiguity also provides a novel explanation for several long-running debates in the literature. For example, Justice Scalia's repeated frustration over the Supreme Court's inability to apply consistently even the simplest principles of textualism is easily explained as the consequence of a legislative-judicial interpretive equilibrium that requires ambiguity in order to permit mixed-game strategies. Supreme Court justices are smart enough to follow Justice Scalia's rigorous

effective communication and of preserving the separation of powers by generally deferring to the legislature's policy choices.

Id. at 400 .

182. See, e.g., id.; Ronald Dworkin, Comment, in A MATTER OF INTERPRETATION 11516 (Antonin Scalia ed., 1997) (emphasizing the impossibility of interpreting text without reference to non-textual intent).

183. The observation that a level of imprecision is consistent with the joint equilibrium preferred by legislators and courts may provide a solution to a mystery posed by Justice Scalia. Justice Scalia observes that the "American law of statutory interpretation" is "so utterly unformed ... that not only is its methodology unclear, but even its very objective is." SCALIA, supra note 4, at 16 . Justice Scalia also observes that "the American bar and American legal education, by and large, are unconcerned with the fact that we have no intelligible theory" of statutory interpretation. Justice Scalia's observation is reinforced by the Court's practice of not affording stare decisis effect to the methodologies that it employs, thereby leaving different justices free to employ different approaches to statutory construction. Id. at 14. This level of apathy is, we suggest, consistent with a lack of judicial or legislative demand for theories of interpretation that impose greater precision than currently found in the literature. 
approach to statutory construction. The fact that they fail to do so thus reflects a lack of an incentive to be overly precise rather than an inability to be precise. The Court's refusal to jump on the new-textualist bandwagon (assuming that new textualism in fact leads to greater precision and consistency in interpretation) would thus be consistent with the hypothesis that neither the legislature nor the courts want to operate in a regime where the rules of construction produce overly consistent results. 184

Although we must be cautious in drawing broad conclusions from a study that examines the interpretation of two words in a single statute, the thoroughness with which Congress is able to flummox the courts supports a much broader observation: Efforts to impose precision on the interpretation of statutory language can be carried too far because neither Congress nor the courts want to operate in a regime that eliminates ambiguity. If that observation is correct, it follows that much of the effort expended to devise more rigorous interpretive theories may be wasted energy because those techniques generate levels of consistency that are not valued by the legislative and judicial processes. Put another way, new-textualist, intentionalist, expressive, or dynamic theories of statutory interpretation may be intellectually intriguing but pragmatically irrelevant because the dominant coalitions of legislators and judges have reason to reject the levels of precision and consistency generated by each of these analytic approaches. Ambiguity may well be mutually advantageous in the separation of powers game played between the legislature and the judiciary.

Thus, even if the courts could invent a magic black box that could precisely and predictably interpret any statutory text and legislative history, there is good reason to believe that the legislature would not want the courts to use that black box. There is also good reason to believe that the courts would not want to employ such a black box on all occasions. Conscious ambiguity in the design and interpretation of statutes thus may have strong survival characteristics in our multi-branch legal regime.

184. Some of Justice Scalia's critics might argue that he has himself been inconsistent in the application of his own interpretive principles, and that this inconsistency reflects Justice Scalia's own demand for a measure of ambiguity consistent with the expression of his own policy preferences and personal convictions. Justice Scalia and his supporters would reject such hypotheses. See, e.g., Gregory E. Maggs, Reconciling Textualism and the Chevron Doctrine: In Defense of Justice Scalia, 28 CONN. L. REv. 393 (1996) (collecting and responding to certain criticisms of Justice Scalia's consistency in statutory interpretation). 


\section{APPENDIX: STATISTICAL ANALYSIS OF DISTRICT COURT DECISIONS}

This Appendix reports on an analysis of 167 district court rulings that address the "strong inference" standard. Each ruling predates the issuance of a decision addressing the "strong inference" standard by any panel of the court of appeals for the circuit in which the district court resides. Each district court decision thus represents a judicial interpretation that is unconstrained by controlling appellate precedent.

This sample size is sufficiently large to support a series of formal statistical analyses that we apply to test a broad array of hypotheses about statutory construction and judicial behavior. For example, we test whether district courts adopt a dominant interpretation of the "strong inference" standard, or whether their interpretations are scattered and diffuse. We also test a broad array of "legal realist" hypotheses regarding the influence of judicial background, court workload, defendant characteristics, and a host of other variables on the selection of an interpretive standard and on the resolution of the underlying motions to dismiss.

The structure of our analysis is driven in part by the absence of a generally accepted theory that can be relied upon to specify the definition of the dependent variables used in our regression models. Therefore, rather than apply a set of arbitrary restrictions to the data, we develop a broad range of variable definitions and then apply dichotomous and polytomous regression techniques to search for patterns in the data. We report all results, including statistically insignificant results, here and in the online Statistical Appendix to this paper. ${ }^{185}$ We find that the results of our analysis are sensitive to variable definition and to regression techniques. We therefore caution against overinterpreting our findings.

We recognize that our approach is characteristic of a data-mining exercise. We suggest, however, that an analysis of the sort we report here-in which insignificant results are reported along with significant ones, and in which emphasis is placed only on relationships that appear to be robust across a range of variable specifications and regression techniques-is more likely to yield a realistic assessment of the underlying statistical relationships than an analysis that arbitrarily constrains variable definitions or that focuses on statistically significant relationships while obscuring equally plausible relationships that are statistically insignificant. 186

Our analysis of the district court decisions proceeds as follows. Section A of this Appendix describes the sample, the construction of the variables used in the analyses, and the hypotheses to be tested. Section A also summarizes

185. See http://law.stanford.edu/lawreview/gp2001/.

186. See infra notes 220-222 and accompanying text. 
descriptive statistics that characterize the sample, and presents evidence that the legislative ability to obscure here dominates the judicial capacity to interpret. Section B presents a series of univariate regression analyses in which individual explanatory variables are used to search for patterns in judicial decision-making. Section $\mathrm{C}$ describes a series of multivariate logistic and polytomous regressions that search for patterns in judicial behavior that are correlated with the interpretation of the "strong inference" standard and with the resolution of the underlying motions to dismiss. Section D summarizes the findings of our statistical analysis.

\section{A. The Sample, the Data, and the Hypotheses}

\section{The sample.}

Our sample is composed of 167 district court opinions that address the "strong inference" standard. 187 Each of these opinions was issued prior to the earlier of (a) the issuance of any decision addressing the "strong inference" standard by any panel of the court of appeals for the circuit in which the district court resides 188 or (b) April 1, 2000, the cutoff date for our sample.

We identified these decisions through LEXIS and Westlaw searches and supplemented those findings with unreported decisions that we obtained from practitioners who specialize in securities fraud litigation.189 To the extent that we have failed to identify unpublished decisions that would otherwise satisfy

187. The sample was limited to cases in which the court based its decision to grant or to deny a motion to dismiss, in whole or in part, on plaintiffs' ability to plead an adequate complaint under the Reform Act's strong inference standard. Cases were deleted from the sample when the court based its order on plaintiffs' failure to plead an element of a Rule 10b-5 claim other than scienter, and without addressing the strong inference standard. See, e.g., Ganino v. Citizens Utils. Co., 56 F. Supp. 2d 222 (D. Conn. 1999) (failure to plead materiality), rev'd dismissal, 228 F.3d 154 (2d Cir. 2000); Scone Invs., L.P. v. Am. Third Mkt. Corp., 1998 WL 205338 (S.D.N.Y. Apr. 28, 1998) (failure to plead reliance where court states that the strong inference standard "is not an issue in this motion"); Rosenbaum \& Co. v. H.J. Meyers \& Co., No. 97-824, 1997 U.S. Dist. LEXIS 15720 (E.D. Pa. Oct. 9, 1997) (failure to plead misrepresentation or omission); Lindblom v. Mobile Telecomms. Techs. Corp., 985 F. Supp. 161 (D.D.C. 1997) (failure to plead a transaction in connection with the purchase or sale of any security). Cases were also deleted if they were decided on other grounds, such as forum non coveniens or violation of the statute of limitations, without providing guidance as to the appropriate standard. See, e.g., Rhodes v. Omega Research, 38 F. Supp. $2 d 1353$ (S.D. Fla. 1999) (forum non conveniens); In re Westlake Elec. Corp., 982 F. Supp. 1031 (W.D. Pa. 1997) (time barred). A complete list of the opinions in the sample can be found in the Statistical Appendix at http://law.stanford.edu/lawreview/gp2001/.

188. These dates were determined with reference to the appellate decisions reported in Table 1, supra.

189. David Levine of the Securities and Exchange Commission graciously provided most of the unreported decisions. 
the sample definition, we believe that the number of omitted observations is likely to be small. To the extent that these omitted observations reflect a bias in our sample, we reason but cannot demonstrate that the omitted observations are more likely to be unpublished decisions denying motions to dismiss, a proplaintiff outcome. Those orders are most likely to be unreported, and tend to pass with less notice and discussion among members of the bar. Accordingly, if there is a bias in our sample, it likely results in a sample that understates decisions with pro-plaintiff outcomes.

Our sample of 167 observations contains decisions by 116 different judges. It follows that fifty-one ( 30.5 percent) of the decisions in our sample represent a repeat interpretation of the statutory standard by a judge. This fact suggests two competing perspectives of our dataset, and we pursue both in our analysis. The first perspective views each of the 167 observations as an independent opinion that deserves equal weight. This approach can be criticized for overweighting the views of judges who happen to have issued multiple opinions interpreting the "strong inference" standard. This approach can be defended, however, on the ground that judges who tend to decide more class action securities fraud cases are, in fact, more influential with regard to the interpretation and application of the statutory language than other judges. We rely on this view of the data to generate our "All Observations" dataset. The second perspective views each judge in the sample as an independent observation that deserves equal weight. To implement this approach we adjust for the presence of judges with multiple decisions by assigning to those judges a dominant interpretive style variable that corresponds to one of the five interpretive standards described below. 190 Those data define an "Individual Judge" dataset. It is not possible, however, to assign a single "outcome" variable to each judge because the outcomes of individual cases decided by each judge can and do differ even if the judge is consistent in choosing an interpretive standard.

\section{Content analysis and the "interpretive standard" variable.}

A central objective of our analysis is to search for patterns in the interpretation of the "strong inference" standard. Consistent with our analysis of the appellate decisions, we began with a content analysis of each opinion in the sample and characterized each judicial interpretation of the "strong inference" standard according to whether it adopted the Second Circuit standard, followed an Intermediate standard, or adopted the Silicon Graphics standard. We soon discovered, however, that many courts avoided the need to interpret the statute by asserting that the complaint at issue was either (a) so well crafted that it could survive a motion to dismiss under even the strongest

190. See infra pp. 687-689. 
interpretation of the standard or (b) so poorly crafted that it would fail a motion to dismiss under even the weakest interpretation of the standard. In order to capture this strategy of interpretative avoidance, which is consistent with "judicial minimalism" (i.e., a style of judging that calls for a court to decide the minimum number of issues necessary in order to resolve the case at issue), ${ }_{2}^{191}$ we categorized each decision as falling into one of the five following categories:

Satisfies Highest. The complaint's allegations are sufficiently strong that the case would survive a motion to dismiss under even the most stringent interpretation of the statutory standard, but the court expresses no view as to the definition of the standard.

Second Circuit standard. The opinion concludes that the statute codifies the Second Circuit standard, or accepts motive and opportunity pleading as sufficient. 192

Intermediate standard. The opinion concludes that "the mere pleading of notice and opportunity does not, of itself, automatically suffice to raise a strong inference of scienter," but requires instead that "pleadings must set forth sufficient particulars, of whatever kind, to raise a strong inference of the required scienter."193

Silicon Graphics standard. The opinion concludes that "Congress intended to elaborate the pleading requirement above the Second Circuit standard," and rejects pleading based on "a motive to commit fraud and an opportunity to do so." The opinion requires instead that plaintiffs must "plead, in great detail, facts that constitute strong circumstantial evidence of deliberately reckless or conscious misconduct." 194

Fails Lowest. The complaint's allegations are so weak that the complaint would fail a motion to dismiss under even the most lenient interpretation of the statutory standard; or that the complaint fails even to plead fraud with the level

191. See, e.g., SunSTEIN, supra note 11; Cass R. Sunstein, The Supreme Court 1995 Term: Foreword: Leaving Things Undecided, 110 HARV. L. REV. 6 (1996) (describing judicial minimalism as "the phenomenon of saying no more than necessary to justify an outcome, and leaving as much as possible undecided").

192. For pre-PSLRA articulations of the Second Circuit standard see, for example, Acito v. Imcera Group, Inc., 47 F.3d 47, 54 (2d Cir. 1995) and Shields v. CityTrust Bancorp, Inc., 25 F.3d 1124, 1130 (2d Cir. 1994). For post-PSLRA articulations see, for example, Novak v. Kasaks, 216 F.3d 300, 307 (2d Cir.), cert. denied, 121 S. Ct. 567 (2000) and Press v. Chemical Investment Services Corp., 166 F.3d 529, 538 (2d Cir. 1999). See also supra notes 155-164 and accompanying text.

193. See, e.g., In re Baesa Sec. Litig., 969 F. Supp. 238, 241-42 (S.D.N.Y. 1997). The Second Circuit characterized that articulation as not adopting the Second Circuit's pleading standard and as instead strengthening it. Novak, 216 F.3d at 310; see also Bryant v. Avado Brands, Inc., 187 F.3d 1271, 1283 (11th Cir. 1999); In re Comshare, Inc. Sec. Litig., 183 F.3d 542, 550-51 (6th Cir. 1999).

194. In re Silicon Graphics Inc. Sec. Litig., 183 F.3d 970, 974 (9th Cir. 1999). 
of particularity required pursuant to Federal Rule of Civil Procedure 9(b). The court therefore finds it unnecessary to interpret the standard.

We hypothesize that these categories follow an ordinal ranking from most pro-plaintiff to most pro-defendant. A plaintiff would thus prefer to learn that a complaint is so strong that it would survive under any articulation of a standard rather than learn that a complaint survives a motion under the Second Circuit standard, and so on. 195 This ranking allows for the application of certain clustering and polytomous regression techniques, as described below.

Table 2

Distribution of Interpretive Standards

\begin{tabular}{|l|l|l|l|l|}
\hline \multirow{2}{*}{ Pleading Standard } & \multicolumn{2}{|c|}{$\begin{array}{c}\text { All Observations } \\
\text { Sample }\end{array}$} & \multicolumn{2}{|c|}{$\begin{array}{c}\text { Individual Judge } \\
\text { Sample }\end{array}$} \\
\cline { 2 - 6 } & Number & Percent & Number & Percent \\
\hline No Interpretation Necessary: Satisfies Highest standard & 22 & $13.2 \%$ & 14 & $12.1 \%$ \\
\hline Second Circuit standard & 50 & $29.9 \%$ & 40 & $34.5 \%$ \\
\hline Intermediate standard & 28 & $16.8 \%$ & 18 & $15.5 \%$ \\
\hline Silicon Graphics standard & 23 & $13.8 \%$ & 20 & $17.2 \%$ \\
\hline No Interpretation Necessary: Fails Lowest standard & 44 & $26.3 \%$ & 24 & $20.7 \%$ \\
\hline Total & 167 & $100.0 \%$ & 116 & $100.0 \%$ \\
\hline
\end{tabular}

Table 2 describes the distribution of the interpretive standard variable for the "All Observations" and "Individual Judge" datasets. This simple cut of the data generates several significant observations.

Quite striking is the fact that judicial minimalism is the most frequent form of interpretation-or non-interpretation-in the All Observations sample. A total of 66 decisions, or 39.2 percent of that sample, avoid articulating a standard by deciding either that a case is so well pled ( 22 decisions) or poorly pled (44 decisions) that there is no need to wrestle with the thorny interpretive question posed by the "strong inference" standard. The Individual Judge sample displays a similar tendency, though not as strongly. There, 38 judges, or 32.8 percent of the sample, resort to minimalist strategies to avoid the interpretive thicket. 196

195. We recognize that the "Fails Lowest" and "Satisfies Highest" categories (which together constitute a "judicial minimalism" category) conflate judicial conclusions regarding the merits of the underlying complaint with decisions as to the appropriate interpretive standard. We therefore conduct many of our analyses on datasets that exclude decisions that adopt these minimalist approaches.

196. The data also indicate that the incidence of decisions holding that complaints fail to meet the lowest standard, whatever that might be, drops from 26.3 percent of the All Observations dataset to 20.7 percent of the Individual Judge dataset. This pattern indicates 
Once we exclude minimalist decisions from consideration, we can formally apply a series of binomial tests to determine whether the observed decisional patterns are consistent with the hypothesis that the district courts are divided over the proper interpretation of the standard. One method to test whether the courts are evenly divided over the interpretive issue is to examine whether their behavior appears to be random, or, put another way, to test whether the courts, in the aggregate, behave as though they are deciding the issue by tossing a fair coin. The model we test is as follows: If a judge decides to confront the interpretive issue the judge tosses a fair coin. If the coin lands heads, then the judge adopts the Second Circuit standard. If it lands tails then the judge selects a more stringent standard and tosses the coin again, with a second heads now indicating the Intermediate standard and a tails indicating the Silicon Graphics standard. 197

The data in Table 2 are highly consistent with this model for both the All Observations and Individual Judge datasets. 198 At the aggregate level, the district courts appear to be evenly divided as to whether the "strong inference"

that judges who preside more frequently in class action security fraud matters tend to be more skeptical of the merits of such complaints and tend to express their skepticism through minimalist holdings that lead to dismissal.

197. No doubt, if one posits a model in which judges choose among three equally likely interpretations of the statute, then these tests are inappropriate. We do not, however, believe that the text and legislative history of the Act support this alternative reading because the structure of the interpretive debate clearly poses the threshold question in a binary form: Is the Second Circuit standard adopted or rejected? The legislative record is largely silent as to the standard that would be applied if the Second Circuit standard is rejected, and the courts have themselves generated the Intermediate standard and Silicon Graphics standard as the two dominant interpretations that are applied conditional on rejection of the Second Circuit standard.

198. For the All Observations dataset, which has 101 observations that interpret the standard, the approximate 95 percent confidence interval spans 42 to 59 (i.e., any number of heads between 42 and 59 would be consistent with the coin being fair). That range includes the 50 observed "heads" (selections of the Second Circuit standard). The p-value for a result of 50 heads is 1 (i.e., even if a fair coin is tossed 101 times you cannot observe less variation in the sample). A stronger confirmation is not possible.

Of the remaining 51 decisions, the approximate 95 percent confidence interval spans 20 to 31 heads. That range includes the 28 "heads" (selections of the Intermediate standard on the second toss of the coin) observed in that sample. The p-value for a result of 28 heads in 51 trials is 57.6 percent (i.e., in $\mathbf{5 7 . 6}$ percent of trials we should observe fewer than 28 heads in 51 tosses of a fair coin).

For the Individual Judge dataset, which has 78 observations that interpret the standard, the approximate 95 percent confidence interval spans 32 to 46 , a range that includes the 40 observed "heads" (selection of the Second Circuit standard). The p-value for a result of 40 heads is 91.0 percent. Of the remaining 38 decisions, the approximate 95 percent confidence interval spans 14 to 24 heads (selections of the Intermediate standard). The p-value for a result of 18 heads in 38 trials is 87.1 percent.

Additional information regarding these tests and procedures can be found in the Statistical Appendix at http://law.stanford.edu/lawreview/gp2001/. 
pleading requirement incorporates the Second Circuit standard or calls for a stronger interpretation. Further, the opinions that call for a stronger standard are closely split between the Intermediate standard and the Silicon Graphics standard. By this analysis, the district court data are consistent with the hypothesis that the legislative ability to obscure trumps the judicial ability to interpret. We obviously do not suggest that courts interpret statutory language by flipping coins. We do, however, observe that the lack of consistency in the interpretation observed in our sample creates a pattern that is statistically indistinguishable from one that would result if judges in fact tossed coins to resolve this interpretive question.

\section{Content analysis and the "outcome" variable.}

A second central objective of our analysis is to search for patterns in the resolution of these motions to dismiss, and to determine whether the selection of a standard is statistically significant in determining the outcome of a motion to dismiss. Categorizing the outcome of the underlying motion to dismiss is more complex than categorizing an interpretive standard because a motion typically will seek the dismissal of several distinct counts as pled against several distinct individuals, whereas the articulation of an interpretive standard typically calls for the selection of a standard from among a reasonably wellspecified menu of alternatives. Thus, the motion can be granted in whole or in part and with or without prejudice with respect to any portion of the complaint. Our analysis suggests that each resolution of a motion to dismiss can be categorized as falling into one of seven categories:

1. The motion is denied in its entirety.

2. The motion is granted in part, but without prejudice as to any portion that is dismissed.

3. The motion granted in its entirety, but without prejudice as to any portion that is dismissed.

4. The motion is granted in part, but with prejudice only as to some portion that is dismissed.

5. The motion is granted in its entirety, but with prejudice only as to some portion that is dismissed.

6. The motion is granted in part, and with prejudice as to all portions of the complaint that are dismissed.

7. The motion is granted in its entirety, and with prejudice as to the entire complaint.

We hypothesize that these categories also follow an ordinal ranking from most pro-plaintiff to most pro-defendant. Thus, a plaintiff would most prefer that a motion to dismiss be denied in its entirety. The plaintiff would next prefer that if a motion is denied only in part, that the denial be without prejudice as to any part dismissed, and would least prefer that a complaint be 
dismissed in its entirety with prejudice. 199 Again, this ranking allows for the application of certain clustering and polytomous regression techniques, as described below.

A simple breakdown of the outcomes in the 167 decisions in our sample, as displayed in Table 3, is again revealing. The most frequent result-occurring in 34.1 percent of the sample - is that the motion to dismiss is denied in its entirety. The next most common outcome-occurring in 27.5 percent of the sample-is that the motion is granted in its entirety, but without prejudice as to any portion of the complaint. Additionally, in 9 percent of the sample, the motion is granted in part, but without prejudice as to any portion of the complaint. Aggregating these three categories, which we posit to be the most pro-plaintiff, indicates that in 70.7 percent of the sample the motion to dismiss is either denied in its entirety or granted with leave to replead in such a manner as to allow the litigation to continue.

199. We recognize that this ordinal ranking is subject to several critiques. For example, a defendant may fail to move for dismissal of the strongest allegations in a complaint thereby leading to a situation in which a strong complaint survives despite the fact that the entire motion to dismiss might be granted with prejudice. This observation does not, however, suggest any bias in our categorization, nor is this situation likely to arise with great frequency. Also, a plaintiff could argue that her sequence of preference is different than the sequence reflected in our ordinal ranking, particularly over the intermediate categories four through six. We respond to this critique by employing a range of clustering techniques designed to minimize the implications of categorizations in the intermediate classifications. See infra p. 701. 


\section{Table 3}

Distribution of Outcomes

(All Observations)

\begin{tabular}{|l|c|c|}
\hline Outcome & Number & Percent \\
\hline 1. Motion to dismiss denied in entirety & 57 & $34.1 \%$ \\
\hline 2. Motion granted in part, but without prejudice as to any part dismissed & 15 & $9.0 \%$ \\
\hline 3. Motion granted in entirety, but without prejudice as to any part dismissed & 46 & $27.5 \%$ \\
\hline 4. Motion granted in part, but with prejudice only as to some parts dismissed & 3 & $1.8 \%$ \\
\hline 5. Motion granted in entirety, but with prejudice only as to some parts dismissed & 6 & $3.6 \%$ \\
\hline 6. Motion granted in part, and with prejudice as to all parts dismissed & 10 & $6.0 \%$ \\
\hline 7. Motion granted in entirety, and with prejudice as to entire complaint & 30 & $18.0 \%$ \\
\hline Total & 167 & $100 \%$ \\
\hline
\end{tabular}

In contrast, the motion to dismiss is granted with prejudice in its entirety in only 18 percent of the sample. It follows that the plaintiff's complaint moves forward in the litigation, or lives to be re-pled at least in part, in 82 percent of the opinions in our sample.

While instructive, these data must be interpreted with caution. Our data do not capture the subsequent litigation history of complaints that were dismissed without prejudice. It is entirely possible that a material percentage of those complaints were later dismissed with prejudice as to all or a portion of the claims asserted. Our data also do not capture the subsequent appellate history of these decisions. Decisions to dismiss complaints could later be reversed on appeal, even if the appellate court asserts that it agrees with the lower court's interpretive standard.200 Our data should thus be interpreted as measuring outcomes observed at a very specific point in time as litigation progresses through the judicial system, and not as measuring outcomes as of the final disposition of the lawsuit.

\section{Explanatory variables and hypotheses.}

We look to the legal realist tradition, prior empirical literature, and legal commentary regarding judicial interpretation of the "strong inference" provision to identify variables that might explain patterns in the selection of interpretive standards or in the determination of outcomes of motions to dismiss. For example, some studies suggest that the political party of the president who nominates a judge to the bench may be statistically correlated 
with the judge's decision-making behavior, 201 and one study reports that Clinton and Carter appointees are more likely to support "liberal" results in cases involving economic issues. ${ }^{202}$ Other studies find no such correlation. ${ }^{203}$ Some observers also suggest that there are real differences among presidents of the same party, arguing that the simple measurement of party affiliation might be insufficient. 204 In the case of the "strong inference" provision, it is clear from the legislative record that President Clinton preferred the Second Circuit standard to stricter interpretations, while Republican legislators and corporate defense interests supported stricter interpretations of the standard205 The Reform Act's political background can thus be read to support a range of political inclination hypotheses.

Accordingly, for each ruling in our sample, we identified the judge who issued the ruling, the president who nominated that judge to the bench, and that president's party affiliation. ${ }^{206}$ These data were used to generate Clinton, Bush, Reagan, Carter, Ford, Nixon, Johnson, and magistrate variables, ${ }^{207}$ as well as Democrat and Republican variables. In later analyses, because of low counts in the data, we cluster the Ford, Johnson and magistrate variables to create a presidential "Other" variable.

201. See, e.g., Sisk et al., supra note 21 , at 1388 ("In contrast to the sporadic findings of significant correlation on other background variables, studies frequently (but not invariably) have found political party identification to be a significant predictor of judicial voting in ideologically divisive cases."). Empirical work typically uses the party of the nominating president as a proxy for the judge's ideological leanings because that information is much more readily available than the party affiliation of the judge. In practice, the two are extremely highly correlated. Prior empirical work has found that the ideology of the appointing president's party is a powerful predictor of judicial votes. See George, supra note 61 , at 237-38 ("Attitudinal studies have demonstrated that the ideological direction ('liberal' or 'conservative') of the party of a judge's appointing President is a strong predictor of the case votes of Supreme Court and Court of Appeals judges.").

202. Ronald Stidham, Robert A. Carp \& Donald R. Songer, The Voting Behavior of President Clinton's Judicial Appointees, 80 JUDICATURE 16, 19 (1996) (finding that Clinton and Carter appointees voted in liberal direction 62 percent of the time, with Nixon appointees at 48 percent, Ford appointees at 55 percent, Reagan appointees at 49 percent, and Bush appointees at 51 percent).

203. See Ashenfelter et al., supra note 63, at 281 (finding no statistically significant difference between Republican and Democratic judges in civil rights cases).

204. Wald, supra note 64, at 239 ("The Democratic and Republican parties of twenty years ago are far different from those existing today, and so a Carter appointee may well have a different worldview than a Clinton appointee, even though they both consider themselves Democrats.").

205. See supra Part III.

206. The data were obtained from 5 JudiClAL Yellow BooK No. 1 (Fall 1999).

207. Because magistrates are appointed by a separate process, we categorize them distinctly. 


\section{Table 4}

\section{Explanatory Variable Descriptive Statistics}

\begin{tabular}{|c|c|c|c|c|c|c|}
\hline \multirow{2}{*}{\begin{tabular}{|l|} 
Variable \\
Individual Judge Characteristics \\
\end{tabular}} & \multicolumn{3}{|c|}{ All Observations } & \multicolumn{3}{|c|}{ Individual Judge } \\
\hline & Count & Mean & $\begin{array}{l}\text { Std. } \\
\text { Dev. }\end{array}$ & Count & Mean & $\begin{array}{l}\text { Std. } \\
\text { Dev. }\end{array}$ \\
\hline Democrat & 67 & 0.40 & 0.49 & 43 & 0.37 & 0.49 \\
\hline Republican & 100 & 0.60 & 0.49 & 73 & 0.63 & 0.49 \\
\hline Clinton & 55 & 0.33 & 0.47 & 33 & 0.28 & 0.45 \\
\hline Bush & 25 & 0.15 & 0.36 & 20 & 0.17 & 0.38 \\
\hline Reagan & 57 & 0.34 & 0.48 & 41 & 0.35 & 0.48 \\
\hline Carter & 9 & 0.05 & 0.23 & 8 & 0.07 & 0.25 \\
\hline Ford & 2 & 0.01 & 0.11 & 1 & 0.01 & 0.09 \\
\hline Nixon & 11 & 0.07 & 0.25 & 7 & 0.06 & 0.24 \\
\hline Johnson & 3 & 0.02 & 0.13 & 2 & 0.02 & 0.13 \\
\hline Magistrate & 5 & 0.03 & 0.17 & 4 & 0.03 & 0.18 \\
\hline Other & 10 & 0.06 & 0.24 & 7 & 0.06 & 0.24 \\
\hline ABA Rank & 104 & 0.62 & 0.49 & 73 & 0.63 & 0.49 \\
\hline Corp. & 126 & 0.75 & 0.43 & 89 & 0.77 & 0.42 \\
\hline Public Int. & 23 & 0.14 & 0.35 & 13 & 0.11 & 0.32 \\
\hline Prosec. & 96 & 0.57 & 0.50 & 62 & 0.53 & 0.50 \\
\hline Judge & 78 & 0.47 & 0.50 & 48 & 0.41 & 0.49 \\
\hline \multicolumn{7}{|l|}{ District Court Incidence } \\
\hline S.D.N.Y. & 23 & 0.14 & 0.35 & 13 & 0.11 & 0.32 \\
\hline N.D. Cal. & 19 & 0.11 & 0.32 & 8 & 0.07 & 0.25 \\
\hline N.D. Ill. & 11 & 0.07 & 0.25 & 9 & 0.08 & 0.27 \\
\hline E.D.Pa. & 11 & 0.07 & 0.25 & 9 & 0.08 & 0.27 \\
\hline D. Mass. & 8 & 0.05 & 0.21 & 5 & 0.04 & 0.20 \\
\hline D. Minn. & 8 & 0.05 & 0.21 & 5 & 0.04 & 0.20 \\
\hline C.D. Cal. & 7 & 0.04 & 0.20 & 7 & 0.06 & 0.24 \\
\hline N.D. Tex. & 6 & 0.04 & 0.19 & 3. & 0.03 & 0.16 \\
\hline Other & 74 & 0.44 & 0.50 & 57 & 0.49 & 0.50 \\
\hline \multicolumn{7}{|l|}{ Defendant Characteristics } \\
\hline High Tech & 67 & 0.40 & 0.49 & 43 & 0.37 & 0.49 \\
\hline \multicolumn{7}{|c|}{ Timing and Sequencing Characteristics } \\
\hline Quarter & $\mathrm{n} / \mathrm{a}$ & 9.48 & 3.05 & $\mathrm{n} / \mathbf{a}$ & 9.26 & 3.14 \\
\hline MultCase & 53 & 0.49 & 0.92 & $\mathrm{n} / \mathrm{a}$ & $\mathbf{n} / \mathbf{a}$ & $\mathbf{n} / \mathbf{a}$ \\
\hline RptJdg. & 84 & 0.50 & 0.50 & $\mathrm{n} / \mathrm{a}$ & $\mathbf{n} / \mathbf{a}$ & $\mathbf{n} / \mathbf{a}$ \\
\hline Total & 167 & $\mathbf{n} / \mathbf{a}$ & $\mathbf{n} / \mathbf{a}$ & 116 & $\mathbf{n} / \mathbf{a}$ & $\mathbf{n} / \mathbf{a}$ \\
\hline
\end{tabular}


Table 4 describes the counts, means, and standard deviations for several of the explanatory variables included in our analysis. As described in that table, of the 167 opinions in the sample, 100 (59.9 percent) were issued by judges appointed by Republican presidents and 67 ( 40.1 percent) were issued by judges appointed by Democratic presidents. The large majority of the Democratic nominees were Clinton appointees, 55 of 67 (82.1 percent). Bush appointees constitute one quarter of the Republican sample (25 of 100), and Reagan appointees constitute more than half (57 of 100). The data for the Individual Judge sample are not remarkably different.

Literature also suggests that a judge's experience prior to nomination can be correlated with behavior on the bench. To capture a judge's prior experience we defined a cluster of five variables:

$A B A$ rating (" $A B A$ Rank").208 In the opinion of some, this variable is a measure of judicial qualifications, but others view it as a controversial factor that may be correlated with a liberal inclination;209

Corporate representation experience ("Corp.").210 This factor may be correlated with an inclination to adopt pro-defendant positions;

Public interest representation experience ("Public Int."). ${ }^{211}$ This factor may be correlated with an inclination to adopt pro-plaintiff positions;

208. The data were obtained from the Federal Judges Biographical Database, Federal Judicial Center, and were very kindly supplied to us by Bruce Ragsdale, Chief Historian for the Federal Judicial Center. Because the ABA switched from a four-part rating scale (Exceptionally Well Qualified, Well Qualified, Qualified, Not Qualified), to a three-part scale (Well Qualified, Qualified, Not Qualified) during the period in which the judges in our sample were appointed, we coded Exceptionally Well Qualified and Well Qualified as the same. See Sisk et al., supra note 21, at 1421 n.198. No judges in our sample were rated Not Qualified. Accordingly, we coded judges rated as qualified with a 0 , and judges who were exceptionally well qualified, or well qualified, as a 1 .

209. The Bush administration in 2001 terminated the American Bar Association's formal evaluation role in the judicial nomination process. Critics of the ABA had complained of a liberal tendency in its evaluation process. See, e.g., James Lindgren, Yes, the ABA Rankings on Judicial Nominees Are Biased, WALl ST. J., Aug. 6, 2001, at A13. Supporters of the ABA participation emphasized the organization's focus on professionalism. Editorial, The White House and the Bar, N.Y. TIMEs, Mar. 23, 2001, at A18; see also RICHARD A. POSNER, THE FEDERAL COURTS: CRISIS AND REFORM 30 (1985) ("The screening function performed by the American Bar Association's Standing Committee on the Judiciary, although in my opinion unduly biased in favor of candidates having extensive experience as trial lawyers, assures that most candidates will have a minimum competence.").

210. We reviewed the ALMANAC OF THE FEDERAL JUDICIARY and MARTINDALE HUBBELL to determine whether the judge had worked for a law firm that represented corporate clients or had served in a corporate general counsel's office.

211. We reviewed the Almanac OF THE FedERAL Judiciary and MARTINDALE HUBBELL to determine whether a judge had public interest representation experience in his or her background. 
Prosecutorial experience ("Prosec.").212 This factor may be correlated with a willingness to believe allegations contained in complaints, and hence be viewed as pro-plaintiff;

Prior experience as a judge in state court or as a federal magistrate ("Judge").213 We express no view as to inclinations that might be correlated with such experience.

We find that 104 (62.3 percent) of the opinions in our database were written by judges who were exceptionally well qualified or well qualified, indicating that 63 (37.7 percent) were written by judges who were ranked as qualified. We also find that 126 of the decisions, 75.5 percent of the sample, were written by judges with corporate experience. Judges with public interest backgrounds wrote 23 decisions, or 13.8 percent of the sample. Judges with prosecutorial background wrote 96 decisions, or 57.5 percent of the sample, and judges with judicial experience prior to their appointment to the federal bench wrote 78 decisions, or 46.7 percent of the sample. Because these categories are not mutually exclusive, the percentages sum to well over 100 percent. The data for the Individual Judge sample differ primarily in that the incidence of judges with a public interest background appears to be lower, 11 percent of the Individual Judge sample, rather than 32 percent of the All Observation sample.

Literature further suggests that the district in which the judge sits may correlate with the judge's decision-making behavior, particularly when industry influences are geographically concentrated.214 In the case of securities fraud litigation, lawsuits against high-technology firms tend to cluster in Silicon Valley, where they are heard in the Northern District of California. Litigation against financial service providers tends to cluster in the Southern District of New York. We accordingly identified the district in which each decision was issued and generated binary variables corresponding to each of the eight districts that accounted for the largest volume of litigation in our sample: (1) S.D.N.Y., (2) N.D. Cal., (3) N.D. Ill., (4) E.D. Pa., (5) D. Mass., (6) D. Minn., (7) C.D. Cal., and (8) N.D. Tex. Together, these eight districts account for 56 percent (93 of 167) of the decisions and 51 percent (59 of 116) of the judges in our two datasets. Because of the small number of observations in each of the remaining districts, those districts were clustered in a ninth "Other" category.

212. We reviewed the ALMANAC OF THE FEDERAL JUDICIARY and MARTINDALE HUBBELl to determine whether a judge had prosecutorial experience in his or her background.

213. We reviewed the ALMANAC OF THE FEDERAL JUDICLARY and MARTINDALE HUBBELl to determine whether a judge had prior judicial experience in his or her background.

214. Lawrence Baum, The Puzzle of Judicial Behavior 29 (1997) ("Some research on federal district judges indicates that judges may be responsive to their districts because of a desire for public support and approval."). 
Table 4 details the distribution of both datasets by district court. The Southern District of New York provides the largest portion of both samples: 13.7 percent of the All Observations dataset and 11 percent of the Individual Judge dataset. The Northern District of California is next most represented in the All Observations dataset with 11.7 percent, but represents only 7 percent of the Individual Judge sample. After that, representation falls off rapidly in the four next-most frequent districts listed in Table 4.

The identity of a district court can, however, operate as a proxy for a variety of other variables that describe salient characteristics of a court's operations. For example, courts with heavier docket loads, whether measured in the aggregate or on a per-judge basis, might operate differently than courts that hear fewer cases. Here, two theories with opposite implications could describe a court's behavior. On the one hand, a judge sitting in a busy court could adopt a higher pleading standard in order to make it easier to dismiss claims and thereby help clear dockets. On the other hand, judges could believe that it takes more time to write a reasoned decision granting some or all of a motion to dismiss and that the burden on the court is minimized if the court simply denies the motion because the result is likely to be a settlement that requires fewer judicial resources to monitor. ${ }^{215}$ Alternatively, judges may pay no attention to docket-load factors in the resolution of class action securities fraud cases because they constitute a small percentage of the cases actually heard by the court, or because they view such considerations as unprofessional as applied to these cases. We therefore have no a priori estimate of the effect of this variable, and, to test the implications of docket-load factors, we collected and generated the following three variables for each decision in the database:

Judgeships. ${ }^{216}$ The number of authorized judgeships in the district in which the case was filed.

Aggregate Docket. ${ }^{217}$ The weighted filings per district as calculated by the Administrative Office of the United States Courts.

Docket per Judge. ${ }^{218}$ The weighted filings for that district divided by the number of authorized judgeships in that district.

The frequency with which courts hear class action securities fraud lawsuits can also influence the court's perspective, separate and apart from workload characteristics. In particular, if repeated exposure to class action securities

215. We are grateful to Professor Bernard Black of Stanford Law School for this observation.

216. AdMINISTRATION OfFICE OF THE UNITED States COURTS, REPORT to CONGRESS ON THE OPTIMAL UTILIZATION OF JUdiCLAL RESOURCES 29-31, tbl. 1 (1998), available at http://www.uscourts.gov/publications.html.

217. Id.

218. Id. 
fraud complaints within a district tends to cause suspicion about that style of litigation, then the data may be consistent with the hypothesis that familiarity breeds skepticism, if not contempt, for class action securities fraud lawsuits. To test for this pattern, we generated two additional variables:

SFCA Docket. The aggregate count of securities fraud class action cases pending in that district as of year-end 1999.219

SFCA per Judge. The SFCA Docket statistic divided by the number of authorized judgeships in that district.220

The claim is also made that complaints against technology issuers are weaker than complaints against other issuers. ${ }^{221}$ If this claim is correct, then one would expect to see a greater incidence of pro-defendant interpretations and/or rulings in cases involving technology issuers or in districts with greater exposure to technology litigation. To test for this effect we define three additional variables designed to reflect the technology status of individual defendant issuers and the intensity with which district courts tend to hear hightechnology cases.

High Tech. This variable measures whether the issuer named in the complaint that gives rise to the decision in our database is a high-technology company. 222

Tech Intensity. This variable measures the number of high-technology opinions in that district divided by the total number of opinions in that district, to describe the percentage of decisional activity in that district attributable to litigation involving high-technology issuers.

Tech/Judge. Number of opinions involving high-technology issuers in that district ("High Tech") divided by number of judges in the district.223

219. The data were obtained from the Stanford Securities Class Action Clearinghouse, at http://www.securities.stanford.edu. Because this statistic measures the number of securities fraud actions filed, and not the number of opinions issued, it is substantially larger than the number of opinions reported in our sample in each district.

220. See supra note 216 for source of judge data.

221. See, e.g., Common Sense Legal Reforms Act of 1995, H.R. 10, 104th Cong. If 601 (1995) (statement of Rep. Bliley).

222. High-technology issuers operate in the computer hardware, software, telecommunications, or pharmaceutical industries, as categorized by Bloomberg Data Services. See http://www.bloomberg.com and industry categorization for each issuer listed in the All Observations dataset.

223. See supra note 216 for source of judge data. 
Table 5

District Court Characteristics (All Observations)

\begin{tabular}{|c|c|c|c|c|c|c|c|c|c|}
\hline $\begin{array}{l}\text { District } \\
\text { Court }\end{array}$ & Opinions & Judges & $\begin{array}{c}\text { Aggregate } \\
\text { Docket }\end{array}$ & $\begin{array}{c}\text { Docket } \\
\text { per } \\
\text { Judge }\end{array}$ & $\begin{array}{c}\text { SFCA } \\
\text { Docket }\end{array}$ & $\begin{array}{c}\text { SFCA per } \\
\text { Judge }\end{array}$ & High Tech & $\begin{array}{l}\text { High Tech } \\
\text { Intensity }\end{array}$ & Tech/Judge \\
\hline S.D.N.Y. & $\begin{array}{c}23 \\
(13.5 \%)\end{array}$ & $\begin{array}{c}28 \\
(3.3 \%)\end{array}$ & $\begin{array}{l}13,552 \\
(3,0 \%)\end{array}$ & 484 & $\begin{array}{c}81 \\
(6.2 \%)\end{array}$ & 2.89 & $\begin{array}{c}6 \\
(9.0 \%)\end{array}$ & $\overline{0.26}$ & 0.21 \\
\hline N.D. Cal. & $\begin{array}{c}19 \\
(11.4 \%)\end{array}$ & $\begin{array}{c}14 \\
(1.7 \%)\end{array}$ & $\begin{array}{c}6,286 \\
(1.4 \%)\end{array}$ & 449 & $\begin{array}{c}80 \\
(6.2 \%)\end{array}$ & 5.71 & $\begin{array}{c}17 \\
(25.4 \%)\end{array}$ & 0.89 & 1.21 \\
\hline N.D. IIL & $\begin{array}{c}11 \\
(6.6 \%)\end{array}$ & $\begin{array}{c}22 \\
(2.6 \%)\end{array}$ & $\begin{array}{c}8,712 \\
(1.9 \%)\end{array}$ & 396 & $\begin{array}{c}22 \\
(1.7 \%)\end{array}$ & 1.00 & $\begin{array}{c}5 \\
(7.5 \%)\end{array}$ & $\overline{0.45}$ & 0.23 \\
\hline E.D. Pa. & $\begin{array}{c}11 \\
(6.6 \%)\end{array}$ & $\begin{array}{c}23 \\
(2.7 \%)\end{array}$ & $\begin{array}{c}9,016 \\
(2.0 \%)\end{array}$ & 392 & $\begin{array}{c}26 \\
(2.0 \%)\end{array}$ & 1.13 & $\begin{array}{c}3 \\
(4.5 \%)\end{array}$ & 0.27 & 0.13 \\
\hline D. Mass. & $\begin{array}{c}8 \\
(4.8 \%)\end{array}$ & $\begin{array}{c}13 \\
(1.5 \%)\end{array}$ & $\begin{array}{c}4,251 \\
(0.9 \%)\end{array}$ & 327 & $\begin{array}{c}34 \\
(2.6 \%)\end{array}$ & 2.62 & $\begin{array}{c}7 \\
(10.5 \%)\end{array}$ & 0.88 & $\overline{0.54}$ \\
\hline D. Mlnn. & $\begin{array}{c}8 \\
(4.9 \%)\end{array}$ & $\begin{array}{c}7 \\
(0.8 \%)\end{array}$ & $\begin{array}{c}3,010 \\
(0.7 \%)\end{array}$ & 430 & $\begin{array}{c}16 \\
(1.2 \%)\end{array}$ & 2.29 & $\begin{array}{c}3 \\
(4.5 \%)\end{array}$ & 0.29 & 0.43 \\
\hline C.D. Cal. & $\begin{array}{c}7 \\
(4.2 \%)\end{array}$ & $\begin{array}{c}27 \\
(3.2 \%)\end{array}$ & $\begin{array}{l}12,177 \\
(2.7 \%)\end{array}$ & 451 & $\begin{array}{c}64 \\
(4.9 \%)\end{array}$ & 2.37 & $\begin{array}{c}3 \\
(4.5 \%)\end{array}$ & 0.29 & 0.11 \\
\hline N.D.Tex. & $\begin{array}{c}6 \\
(3.6 \%)\end{array}$ & $\begin{array}{c}12 \\
(1.4 \%)\end{array}$ & $\begin{array}{c}6,384 \\
(1.4 \%)\end{array}$ & 532 & $\begin{array}{c}29 \\
(2.2 \%)\end{array}$ & $\overline{2.42}$ & $\begin{array}{c}0 \\
(0.0 \%)\end{array}$ & 0.00 & 0.00 \\
\hline Other & $\begin{array}{c}74 \\
(44.3 \%)\end{array}$ & $\begin{array}{c}704 \\
(82.8 \%)\end{array}$ & $\begin{array}{l}391,083 \\
(86.1 \%)\end{array}$ & 556 & $\begin{array}{c}948 \\
(72.9 \%)\end{array}$ & 1.35 & $\begin{array}{c}23 \\
(34.3 \%)\end{array}$ & 0.31 & 0.03 \\
\hline Total & $\begin{array}{c}167 \\
(100 \%)\end{array}$ & $\begin{array}{c}850 \\
(100 \%)\end{array}$ & $\begin{array}{l}454,471 \\
(100 \%)\end{array}$ & 534.7 & $\begin{array}{c}1,300 \\
(100 \%)\end{array}$ & 1.53 & $\begin{array}{c}67 \\
(100 \%)\end{array}$ & 0.40 & 0.08 \\
\hline
\end{tabular}

Table 5 describes the distribution of these variables in the All Observation database by district court and for the sample as a whole. Several patterns are immediately apparent from these data. Most striking is the fact that the Northern District of California displays a remarkably higher number of securities fraud actions per judge, 5.71, than the sample average of 1.53. The Northern District of California is also home to a disproportionate share of hightechnology opinions: While decisions issued in that district constitute 11.4 percent of the total sample, they account for 25.4 percent of the hightechnology opinions. The same pattern is apparent in the technology intensity measure that indicates that 89 percent of the opinions issued in the Northern District of California are related to the high-technology issuers whereas for the sample as a whole the average High Tech intensity is 40 percent. Similarly, the number of high-technology opinions per judge in the Northern District of California is 1.21 , whereas the sample average is 0.08 . No other pattern in the data appears to be quite as remarkable. If the hypothesis that familiarity breeds skepticism is correct, particularly with respect to high-technology matters, then we would expect to observe that decisionmaking patterns in the Northern District of California differ from the average pattern observed nationwide.

In addition, if district court judges are influenced by decisions issued by other district court judges, then a time trend may be apparent in the data. To test for this effect, we defined the following variable:

Quarter. This variable is defined as "1" if the opinion was issued in the second quarter of 1996, the earliest date for any opinion in the sample, and 
increases by 1 for each subsequent quarter. As described in Table 4, the Quarter variable indicates that the average opinion was issued in Quarter 9 of our sample, which corresponds to the second quarter of 1998.

The substance of a decision can also depend on whether the judge ruling on a matter is viewing it as a question of first impression, or whether the court has already wrestled with the issue. This is again a variant of the "familiarity breeds skepticism" hypothesis. To address this possibility we define two additional variables:

(1) Multiple Case ("MultCase"). This variable assumes the value " 0 " if the opinion at issue is the first or only decision issued by that judge in the database. It assumes the value " 1 " if it is the second issued opinion, " 2 " if it is the third, and so on. Table 4 indicates that the average value for MultCase is 0.49 , which corresponds to the average case being halfway between the first and second decision issued by the average judge.

(2) Repeat Judge ("RptJdg."). This binary variable assumes the value " 1 " if the judge issuing that ruling has more than one opinion in the database, and " 0 " otherwise. The RptJdg. value of 84 indicates that 84 of the decisions in the database are by judges with more than one decision and implies that 83 decisions are by judges with a single decision in the database.

Table 6 summarizes the definitions of these variables.

\section{Table 6}

Summary Definition of Explanatory Variables

\begin{tabular}{|l|l|l|}
\hline Variable Name & Definition \\
\hline Individual Judge Characteristics & $=0$ & Unless \\
\hline Democrat & $=1$ & if nominated by Democratic president \\
\hline Republican & $=1$ & if nominated by Republican president \\
\hline Clinton & $=1$ & if nominated by President Clinton \\
\hline Bush & $=1$ & if nominated by President Bush \\
\hline Reagan & $=1$ & if nominated by President Reagan \\
\hline Ford & $=1$ & if nominated by President Ford \\
\hline Nixon & $=1$ & if nominated by President Nixon \\
\hline Johnson & $=1$ & if nominated by President Johnson \\
\hline Magistrate & $=1$ & if magistrate judge \\
\hline Other & $=1$ & if nominated by Presidents Johnson, Ford, or Carter, or if Magistrate \\
\hline ABA Rank & $=1$ & if exceptionally well qualified or well qualified (0 implies qualified) \\
\hline Corp. & $=1$ & if comporate background is identified \\
\hline Public Int. & $=1$ & if public interest background is identified \\
\hline
\end{tabular}




\section{Table 6}

(Continued)

Summary Definition of Explanatory Variables

\begin{tabular}{|c|c|c|}
\hline \multicolumn{2}{|l|}{ Variable Name } & \multirow{2}{*}{\begin{tabular}{|l|} 
Definition \\
if prosecutorial background is identified \\
\end{tabular}} \\
\hline Prosec. & $=\mathbf{I}$ & \\
\hline Judge & $=1$ & if judicial background is identified \\
\hline MultCase & $=0$ & $\begin{array}{l}\text { if the decision represents the first SFCA case the judge has seen; } \\
\text { value increases by } 1 \text { for each subsequent SFCA case }\end{array}$ \\
\hline RptJdg. & $=1$ & if the judge had more than 1 SFCA case in the sample \\
\hline Quarter & $=1$ & $\begin{array}{l}\text { if case was decided in Q2 of 1996; value increases by } 1 \text { to } 16 \text { for each } \\
\text { subsequent quarter }\end{array}$ \\
\hline Defendant Issuer Characteristies & $=0$ & Unless \\
\hline High Tech & $=1$ & if defendant issuer is a high-technology firm \\
\hline District Court Characteristics & $=0$ & Unless \\
\hline S.D.N.Y. & $=1$ & if decided in S.D.N.Y. \\
\hline N.D.Cal. & $=1$ & if decided in N.D. Cal. \\
\hline N.D. lll. & $=1$ & if decided in N.D. Ill. \\
\hline E.D. Pa & $=1$ & if decided in E.D. Pa. \\
\hline D. Mass. & $=1$ & if decided in D. Mass. \\
\hline D. Minn. & $=1$ & if decided in D. Minn. \\
\hline C.D. Cal. & $=1$ & if decided in C.D. Cal. \\
\hline N.D. Tex. & $=1$ & if decided in N.D. Tex. \\
\hline Other & $=1$ & $\begin{array}{l}\text { if not decided in any of the eight district courts for which a separate } \\
\text { variable is defined. }\end{array}$ \\
\hline Aggregate Docket & & Total Filings in the District \\
\hline Docket per Judge & & Total Filings per Judge in the District \\
\hline SFCA Docket & & Number of SFCA Cases \\
\hline SFCA per Judge & & Number of SFCA Cases / Number of Judges \\
\hline Tech Intensity & & Percentage of SFCA Docket relating to high-technology issuers \\
\hline Tech/Judge & & Number of Tech Cases / Number of Judges \\
\hline
\end{tabular}

\section{Multicollinearity analysis.}

In order to measure the potential for multicollinearity among these explanatory variables, we examined the variance-covariance matrix and discovered four clusters of variables that display correlation coefficients in excess of 0.5 . These clusters are described in Table 7 for the All Observations sample.224 


\section{Table 7}

Multicollinearity Analysis

(All Observations)

(a) The N.D. Cal. Cluster

\begin{tabular}{|r|r|r|r|r|r|}
\hline & N.D. Cal & \multicolumn{1}{|c|}{$\begin{array}{c}\text { SFCA } \\
\text { Docket }\end{array}$} & $\begin{array}{r}\text { SFCA per } \\
\text { Judge }\end{array}$ & $\begin{array}{c}\text { Tech } \\
\text { Intensity }\end{array}$ & Tech/Judge \\
\hline N.D. Cal. & 1.000 & 0.549 & 0.815 & 0.810 & 0.929 \\
\hline SFCA Docket & 0.549 & 1.000 & 0.808 & 0.421 & 0.616 \\
\hline SFCA per Judge & 0.815 & 0.808 & 1.000 & 0.693 & 0.846 \\
\hline Tech Intensity & 0.810 & 0.421 & 0.693 & 1.000 & 0.899 \\
\hline Tech/Judge & 0.929 & 0.616 & 0.846 & 0.899 & 1.000 \\
\hline
\end{tabular}

(b) The S.D.N.Y. Cluster

\begin{tabular}{|r|r|r|r|r|}
\hline & S.D.N.Y. & \multicolumn{1}{c|}{$\begin{array}{c}\text { SFCA } \\
\text { Docket }\end{array}$} & $\begin{array}{c}\text { Aggregate } \\
\text { Docket }\end{array}$ & $\begin{array}{r}\text { Docket per } \\
\text { Judge }\end{array}$ \\
\hline S.D.N.Y. & 1.000 & 0.626 & 0.585 & 0.023 \\
\hline SFCA Docket & 0.626 & 1.000 & 0.587 & -0.032 \\
\hline Aggregate Docket & 0.585 & 0.587 & 1.000 & 0.342 \\
\hline Docket per Judge & 0.023 & -0.032 & 0.342 & 1.000 \\
\hline
\end{tabular}

(c) The Multiple Decision Cluster

\begin{tabular}{|r|r|r|}
\hline & MultCase & RptJdg. \\
\hline MultCase & 1.000 & 0.534 \\
\hline RptJdg. & 0.534 & 1.000 \\
\hline
\end{tabular}

(d) The Presidential Cluster

\begin{tabular}{|r|r|r|r|r|}
\hline & Democrat & Republican & Clinton & \multicolumn{1}{|c|}{ Reagan } \\
\hline Democrat & 1.000 & -1.000 & 0.856 & -0.589 \\
\hline Republican & -1.000 & 1.000 & -0.856 & 0.589 \\
\hline Clinton & 0.856 & -0.856 & 1.000 & -0.504 \\
\hline Reagan & -0.589 & 0.589 & -0.504 & 1.000 \\
\hline
\end{tabular}

Panel (a) of Table 7 describes the "N.D. Cal. Cluster." It shows high correlations among five variables: presence in the Northern District of California, the size of the securities fraud docket in a district, the incidence of

Judge sample can be found in the Statistical Appendix at http://law.stanford.edu/lawreview/ gp2001\%. 
securities fraud litigation on a per judge basis, the intensity of litigation against high-technology issuers, and the number of technology-related decisions on a per-judge basis. These correlations arise because the Northern District of California has a high concentration of class action securities fraud litigation as well as a high concentration of litigation involving technology issuers. The concentration is high whether measured on an aggregate or per-judge basis. These strong correlations may make it difficult to disentangle the explanatory effect of any one of these variables from any of the others. More particularly, if behavior in the Northern District of California seems to differ from behavior in other districts, it may be difficult to determine whether the difference is attributable to the intensity of technology litigation in the district, to the intensity of overall securities fraud litigation in the district, or to some other attribute associated with the Northern District.

Panel (b) describes the "S.D.N.Y. Cluster." It shows high correlations between presence in the Southern District of New York, the aggregate size of the class action securities fraud docket, and the aggregate size of the court's civil docket. These correlations, however, tend to be materially lower than the correlations observed in the N.D. Cal. Cluster.

Panel (c) shows an expected correlation between the numerical sequence in which a judge has issued a decision (i.e., whether the decision is the first, second, third, etc., decision issued by that judge as captured by the MultCase variable) and whether the judge has more than one decision in the database (as captured by the RptJdg. variable).

Panel (d) shows an expected set of correlations involving party status of the nominating president and the identity of the nominating president. Democratic and Republican affiliations are perfectly negatively correlated, as should be expected. Correlations in excess of 0.5 arise only for the Clinton and Reagan presidential variables because those variables account for the largest portions of the Democratic and Republican sub-samples.

\section{B. Univariate Analyses}

The impression among practitioners is that decisions in the Northern District of California tended to be more pro-defendant even prior to the Ninth Circuit's decision in Silicon Graphics. ${ }^{225}$ To test for the accuracy of this and other perspectives that might be based on a univariate perspective of the data, and to illustrate the differences that can arise between univariate and multivariate analyses, we here present a series of univariate regression analyses that we subsequently supplement with a series of multivariate regression analyses. The first set of univariate regressions search for correlations with the 
selection of the interpretive standard. The second set search for correlations with the outcome of the motion to dismiss.

Significantly, there is no developed theory to guide us as to the correct specification of dependant variables in these regressions, or as to the correct specifications of the regressions themselves. We therefore test several different specifications of the dependent variables. We also apply dichotomous and polytomous regression techniques in our search for patterns in the data.226 This approach obviously opens us to the critique that we are engaged in "data mining" or "data snooping,"227 and that we are about to "torture the data until it confesses."228 To address this legitimate concern, the Statistical Appendix to this page reports results that are statistically insignificant and not replicated in this published report. By so disclosing all results-significant and insignificant alike-we respond to data mining concerns and allow the reader better to form a view as to the meaning of the results. We view this approach as preferable to arbitrarily choosing variable definitions and statistical techniques designed to maximize the appearance of statistically significant relationships. Moreover, we consider statistically significant relationships to be analytically meaningful only if they are clearly robust in the sense that they are statistically significant across a large number of model specifications and regression techniques.229

\section{Interpretive standard analysis.}

As previously explained, ${ }^{230^{\circ}}$ five different interpretive standards arise in the databases: (1) no standard applied because the complaint was viewed as so strong that it satisfied even the highest pleading standard, whatever that might be; (2) the Second Circuit standard applied; (3) an Intermediate standard applied; (4) the Silicon Graphics standard applied; or (5) no standard applied because the complaint was viewed as so weak that it failed even the weakest pleading standard, whatever that might be.

226. For a description of these techniques, please refer to the Statistical Appendix at http://law.stanford.edu/lawreview/gp2001/.

227. See, e.g., David Freedman, Robert Pisani \& Roger PuRves, Statistics 495500 (2d ed. 1991); PETER KENNEDY, A GUIDE TO ECONOMETRICS 76, 159, 164 (2d ed. 1985); Edward E. Leamer, Let's Take the Con out of Econometrics, 73 AM. Econ. REV. 31 (1983); Michael C. Lovell, Data Mining, 65 REv. ECON. \& STAT. 1 (1983); T. Dudley Wallace, Pretest Estimation in Regression: A Survey, 59 AM. J. AGRIC. ECON. 431 (1977). 76.

228. A similar locution is attributed to Ronald Coase in KENNEDY, supra note 227, at

229. For a similar approach see Lovell, supra note 227.

230. See supra pp. 686-687. 
Table 8

Definition of Dichotomous and Polytomous Dependent Variables for Interpretive Standard Regressions

\begin{tabular}{|c|c|c|}
\hline $\begin{array}{c}\text { Dependant } \\
\text { Varlable }\end{array}$ & Defi & nition \\
\hline Dichot 1 & $=0$ & $\begin{array}{l}\text { if no standard was selected because the complaint satisfied the highest standard } \\
\text { Othenvise }\end{array}$ \\
\hline Dichot 2 & $\begin{array}{l}=0 \\
=1\end{array}$ & $\begin{array}{l}\text { or } \\
\text { if no standard was selected because the complaint failed even the lowest standard }\end{array}$ \\
\hline Dichot 3 & $=0$ & $\begin{array}{l}\text { if the Second Circuit standard was seleated, or if no standard was selected because the complaint satisfied } \\
\text { the highest standard } \\
\text { Otherwise }\end{array}$ \\
\hline Dichot 4 & $=0$ & $\begin{array}{l}\text { or } \\
\text { if the Silicon Graphics standard was selected, or if no standard was selected because the complaint } \\
\text { would have failed cven the weakest standard }\end{array}$ \\
\hline Dichot 5 & $\begin{array}{l}=0 \\
=1\end{array}$ & $\begin{array}{l}\text { if the Second Circuit standard was selected } \\
\text { if the Intermediate or Silicon Graphics standard was selected. [All other observations cxcluded] }\end{array}$ \\
\hline Dichot 6 & $\begin{array}{l}=0 \\
=1\end{array}$ & $\begin{array}{l}\text { if the Second Circuit or Intermediate standards were selected } \\
\text { if the Silicon Graphics standard was selected. [All other observations excluded.] }\end{array}$ \\
\hline Polyt I & $\begin{array}{l}=0 \\
=1 \\
=2\end{array}$ & $\begin{array}{l}\text { Second Circuit standard } \\
\text { Intermediate standard } \\
\text { Sllicon Graphics standard. [All other observations excluded.] }\end{array}$ \\
\hline Polyt 2 & $\begin{array}{l}=0 \\
=1 \\
=2\end{array}$ & $\begin{array}{l}\text { Satisfies Highest or Second Circuit standand } \\
\text { Intermediate standard } \\
\text { Silicon Graphics or Fails Lowest standard }\end{array}$ \\
\hline$\widehat{\text { Polyt } 3}$ & $\begin{array}{l}=0 \\
=1 \\
=2 \\
=3 \\
=4\end{array}$ & $\begin{array}{l}\text { Satisfies Highest standard } \\
\text { Second Circuit standard } \\
\text { Intermediate standard } \\
\text { Silicon Graphics standard } \\
\text { Fails Lovest standard }\end{array}$ \\
\hline
\end{tabular}

In order to construct binary variables that reflect these interpretive styles, we clustered these five categories to generate six dichotomous dependent variables according to the definitions provided in Table 8.231 Each of these clusters is defined so that " 0 " represents the more pro-plaintiff interpretation and " 1 " represents the more pro-defendant interpretation. Accordingly, in subsequent regressions, a positive (negative) coefficient on an explanatory variable would represent a pro-defendant (pro-plaintiff) correlation. The structure of this categorization is illustrated in Figure 1.

231. For an explanation of dichotomous logistic regressions, see the Statistical Appendix at http://law.stanford.edu/lawreview/gp2001/. 


\section{Figure 1}

Schematic Representation of the Definition of Dichotomous and Polytomous Dependant Variables for Interpretive Standard Regressions

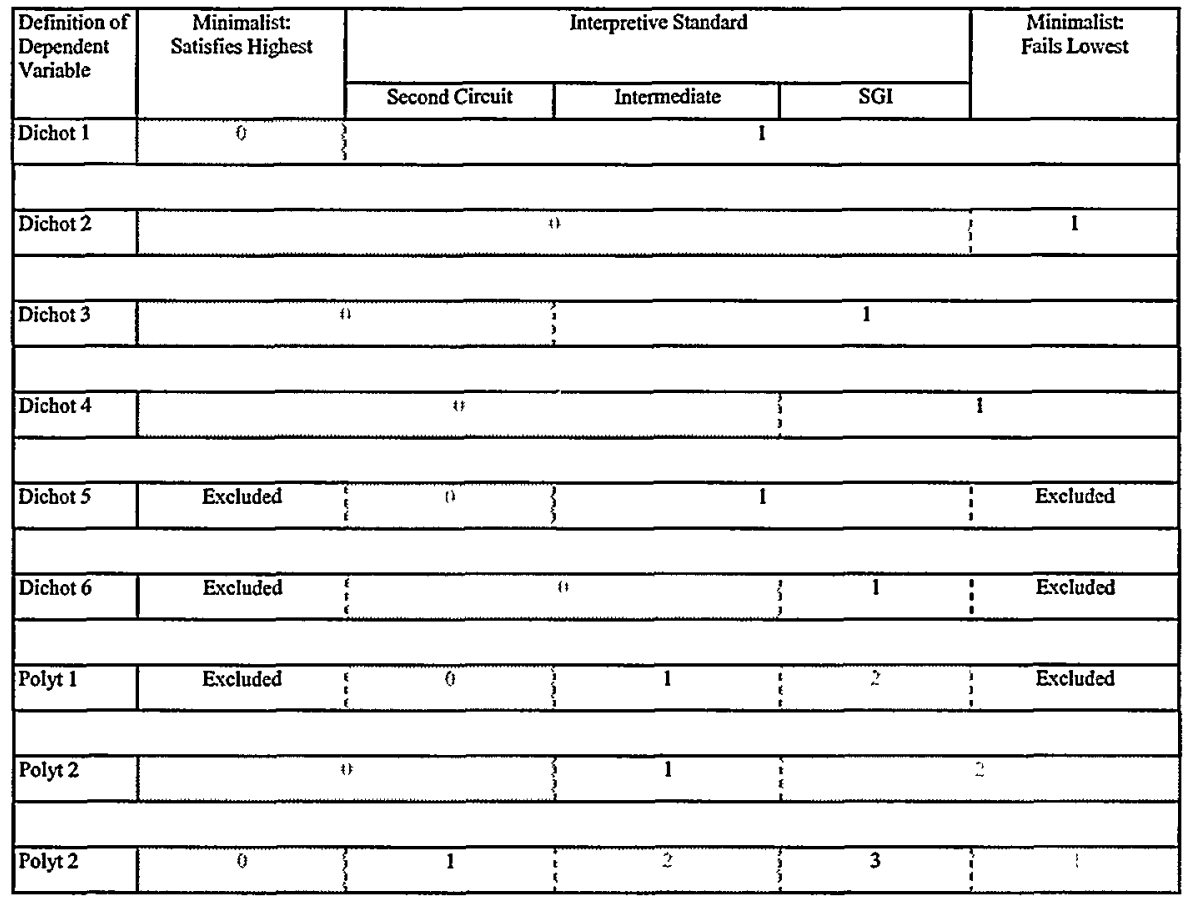

In summary form, Dichot 1 distinguishes opinions that conclude that a complaint satisfies the highest standard from all other outcomes. Dichot 2 distinguishes opinions that conclude that a complaint fails the weakest standard from all other outcomes. These first two categorizations thus test for factors that might be correlated with the most extreme interpretive outcomes that follow an approach consistent with judicial minimalism.

Dichot 3 distinguishes cases that satisfy the highest, or that adopt the Second Circuit standard, from all other decisions. Dichot 4 distinguishes cases that fail the lowest or that adopt the Silicon Graphics standard, from all other decisions. These two categorizations thus test for factors that might be correlated with the two most pro-plaintiff outcomes or with the two most prodefendant outcomes.

Dichot 5 and Dichot 6 exclude the "Fails Lowest" and "Satisfies Highest" observations from the database. They accordingly test for factors correlated with interpretive standards only in opinions that resolve the interpretive question. Put another way, these analyses exclude opinions that practice 
judicial minimalism. Dichot 5 distinguishes decisions that adopt the Second Circuit standard from all others, while Dichot 6 distinguishes decisions that adopt the Silicon Graphics standard from all others.

The Polyt variables are used in a series of three polytomous regressions. 232 In a polytomous regression, the dependent variable assumes three or more values where the values can be ordinally ranked, for example, from most proplaintiff to most pro-defendant. If the dependent variable assumes $\mathrm{K}$ discrete values, the analysis here generates $\mathrm{K}-1$ regression coefficients where each coefficient expresses the increased or decreased likelihood that the specified explanatory variable is correlated with a given ordinal outcome, relative to the baseline value that is measured as the first ordinal state. Thus, if a polytomous variable has three possible states, a positive (negative) first coefficient in the polytomous regression indicates an increased (decreased) likelihood of a correlation with the second ordinal state over the first ordinal state, and a positive (negative) second coefficient indicates an increased (decreased) likelihood of a correlation with the third ordinal state over the first ordinal state. 233

As defined above, Polyt 1 excludes from analysis all opinions that practice judicial minimalism. It ranks the standards so that Polyt $1=0$ as the baseline if the Second Circuit standard is adopted, Polyt $1=1$ if the Intermediate standard is adopted, and Polyt $1=2$ if the Silicon Graphics standard is adopted. Polyt 2 clusters the two most extreme outcomes on each end of the distribution so that Polyt $2=0$ as the baseline if the opinion is "Satisfies Highest" or selects the Second Circuit standard, Polyt $2=1$ if the Intermediate standard is adopted, and Polyt $2=2$ if the opinion is "Fails Lowest" or adopts the Silicon Graphics standard. Polyt 3 is the most refined of the three specifications. It assigns an independent value to each of the five categorizations of the interpretive standard variable, in increasing order of "pro-defendant" status.

Table 9 reports the results of univariate regressions of the explanatory variable on the six different dichotomous characterizations of the interpretive standards variable, as well as on the three different polytomous characterizations, where the regressions are run over All Observations. ${ }^{234}$ Table 10 reports the same results for the Individual Judge dataset. These tables report only statistically significant coefficients. Full reports of statistically insignificant relationships can be found in the Statistical Appendix.

232. For an explanation of polytomous logistic regressions, see the Statistical Appendix at http://law.stanford.edu/lawreview/gp2001/.

233. Technically, the coefficients describe a log-odds ratio, which can be greater than 1.0, whereas a simple probability cannot exceed 1.0. See id.

234. Dichot 5, 6, and Polyt 1 show 101 observations because they omit "Fails Lowest" and "Satisfies Highest" observations. 
Table 9

Pleading Standard

Univariate Regression Analysis

(All Observations)

\begin{tabular}{|c|c|c|c|c|c|c|c|c|c|}
\hline & \multicolumn{6}{|c|}{ Dichotomous Regressions } & \multicolumn{3}{|c|}{ Polytomous Regressions } \\
\hline Variable & Mode11 & Model 2 & Modcl 3 & Mode 4 & Model 5 & Modd 16 & Model1 & Model2 2 & Mode13 \\
\hline Clinton & & & & & & & $\begin{array}{ll}\text { 1) } & 1.0464+106 \\
& 2.106 \\
\text { 2) } & 0.005 \\
& 0.008 \\
\end{array}$ & & \\
\hline Reggan & $\begin{array}{l}1.324+ \\
2.092\end{array}$ & & & & & & & & \begin{tabular}{|ll}
$1)$ & $1.356+$ \\
2) & 1.977 \\
& 1.253 \\
3) & 1.709 \\
& $1.533+$ \\
4) & 2.111 \\
& 1.187 \\
1.700
\end{tabular} \\
\hline Carter & & & $\begin{array}{r}-2.464+ \\
-2.368\end{array}$ & & & & & 1) $\begin{array}{l}-8.346 \\
-0.241 \\
-2.110 \\
-1.963\end{array}$ & \\
\hline Johrson & & & & & & & & & 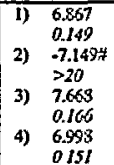 \\
\hline Magistrate & $\begin{array}{l}-2.4244 \\
-2.565\end{array}$ & & & & & & & & \\
\hline N.D.Cal & & $\begin{array}{l}2.3994 \\
4.259\end{array}$ & $\begin{array}{l}1.539+ \\
2.386\end{array}$ & $\begin{array}{l}2.317 \\
3.581\end{array}$ & & & & $\begin{array}{|ll|}\text { 1) } & -7.256 \\
\text { 2) } & -0.2 .122 \\
& 1.977^{\circ} \\
\end{array}$ & \\
\hline N.D. IIL. & & & $\begin{array}{l}-1.1 .894+ \\
-2.382\end{array}$ & $\begin{array}{l}\begin{array}{l}1.9994- \\
1.975\end{array} \\
\end{array}$ & $\begin{array}{l}-2.254+ \\
-2.149\end{array}$ & & & 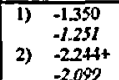 & \\
\hline Other & & $\begin{array}{l}-0.997^{\circ} \\
-2.614^{\circ}\end{array}$ & & & & & & & 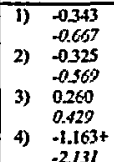 \\
\hline $\begin{array}{c}\text { Aggregate } \\
\text { Docket }\end{array}$ & & & & $\begin{array}{l}-0.092+ \\
-2.209\end{array}$ & & $\begin{array}{l}-0.203^{*} \\
-2.693\end{array}$ & $\begin{array}{ll}\text { 1) } & -0.011 \\
& -0.421 \\
& -0.207 \\
2) & -5.259 \\
& \end{array}$ & $\begin{array}{|ll|}\text { 1) } & 0.010 \\
\text { 2) } & 0.412 \\
& -0.0597 \\
& 4.069\end{array}$ & 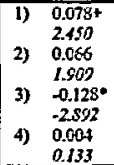 \\
\hline $\begin{array}{l}\text { SFCA } \\
\text { Docket }\end{array}$ & & $0.017^{*}$ & & & & & & & \\
\hline $\begin{array}{c}\text { SFCA per } \\
\text { Judge }\end{array}$ & & $\begin{array}{l}0.41871 \\
3.652\end{array}$ & \begin{tabular}{|l|}
$0.3433 H^{H}$ \\
2.930
\end{tabular} & $\begin{array}{l}0.36774 \\
3.316\end{array}$ & & & & $\begin{array}{|ll|}\text { 1) } & 0.155 \\
\text { 2) } & 0.947 \\
& 0.46 .4 \\
& 3.329\end{array}$ & $\begin{array}{|ll|}\text { 1) } & -0.001 \\
\text { 2) } & -0.003 \\
& 0.157 \\
\text { 3) } & 0.721 \\
\text { 3) } & 0.225 \\
\text { 4) } & 1.03 \\
\text { 4. } & 0.574 \\
\end{array}$ \\
\hline
\end{tabular}


Table 9

(Continued)

Pleading Standard

Univariate Regression Analysis

(All Observations)

\begin{tabular}{|c|c|c|c|c|c|c|c|c|c|}
\hline & \multicolumn{6}{|c|}{ Dicbotomous Regressions } & \multicolumn{3}{|c|}{ Polytomous Regressions } \\
\hline & Medsil & Mode12 & Made13 & Model 4 & Model 5 & Model 6 & Model 1 & Model2 & Modd 3 \\
\hline $\begin{array}{c}\text { Tech } \\
\text { Intersity }\end{array}$ & & $\begin{array}{l}2.4744 \\
3.354\end{array}$ & $\begin{array}{l}2.638^{\circ} \\
2.965\end{array}$ & $\begin{array}{l}2.250^{*} \\
3.057\end{array}$ & & & & $\begin{array}{ll}\text { 1) } & 1.823 \\
& 1.563 \\
\text { 2) } & 2.922^{*} \\
& 3.160\end{array}$ & \\
\hline Techiduda & & $\begin{array}{l}2.012 \% \\
4.262\end{array}$ & $\begin{array}{l}1.610^{*} \\
2.890\end{array}$ & $\begin{array}{l}1.899 \% \\
3.735\end{array}$ & & & & $\begin{array}{ll}1) & 0.285 \\
& 0.327 \\
2) & 1.9764 \\
& 3.358\end{array}$ & \begin{tabular}{ll|} 
1) & 0.850 \\
& 0.067 \\
2) & 0.931 \\
& 0.657 \\
3) & 1.691 \\
& 1.297 \\
$4)$ & $2.997^{*}$ \\
& 2.477
\end{tabular} \\
\hline Proces. & & & & & $\begin{array}{l}0.943+ \\
2279\end{array}$ & & $\begin{array}{ll}1) & 1.952^{*} \\
& 3.109 \\
2) & 0.073 \\
& 0.145\end{array}$ & $\begin{array}{ll}\text { 1) } & 1.792^{*} \\
\text { 2) } & 3.041 \\
& 0.149 \\
& 0439\end{array}$ & $\begin{array}{ll}1) & -0.528 \\
\text { 2) } & -1.019 \\
& 1.424+ \\
\text { 3) } & 2.056 \\
& -0.755 \\
\text { 4) } & -0.755 \\
& -0.093 \\
\end{array}$ \\
\hline MultCase & & & & & & & $\begin{array}{ll}1) & 0.5194 \\
& 2.199 \\
2) & -0.668 \\
& -1.375\end{array}$ & $\begin{array}{ll}\text { 1) } & 0.602^{*} \\
& 2.819 \\
2) & 0.197 \\
& 0.326\end{array}$ & $\begin{array}{|ll|}\text { 1) } & 0.661 \\
& 1.344 \\
\text { 2) } & 1.193 \\
& 2.414 \\
\text { 3) } & -0.037 \\
& -0.057 \\
4) & 0.774 \\
& 1.575 \\
\end{array}$ \\
\hline Obenilfor & 167 & 167 & 167 & 167 & 167 & 167 & 167 & 167 & 167 \\
\hline
\end{tabular}

1) i-Stitustus eppear un itslios below cesthenent vilus

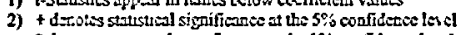

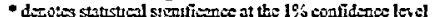

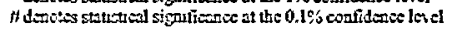

Table 10

Pleading Standard

Univariate Regression Analysis

(Individual Judge Sample)

\begin{tabular}{|c|c|c|c|c|c|c|c|c|c|}
\hline \multirow[b]{2}{*}{ Variable } & \multicolumn{6}{|c|}{ Dichotomous Regressions } & \multicolumn{3}{|c|}{ Polytomous Regressions } \\
\hline & Model 1 & Model 2 & Model 3 & Model 4 & Model 5 & Madel 6 & Model 1 & Model 2 & Model 3 \\
\hline Clinton & & & & & & & & $\begin{array}{ll}1) & 0.925 \\
& 2.036 \\
& 0.168 \\
& 0.449\end{array}$ & \\
\hline Canter & & & & & & & & $\begin{array}{rr}1) & -9.196 \\
-0.265 \\
-11.015 \\
-10.245\end{array}$ & \begin{tabular}{ll} 
) & \multicolumn{1}{c}{0.058} \\
2) & -.0607 \\
& -9.308 \\
3) & -9.217 \\
& -0.519 \\
4) & -9.931 \# \\
& -7.9269
\end{tabular} \\
\hline Johrison & & & & & & & & & $\begin{array}{lc}1) & 7.154 \\
& 0.155 \\
\text { 2) } & -4.074 \text { \# } \\
& >20 \\
\text { 3) } & 7.873 \\
& 0.170 \\
4) & -5.024 \\
& -0.109\end{array}$ \\
\hline Magistrate & $\begin{array}{l}-2.120 \\
-2.028\end{array}$ & & & & & & & & \\
\hline
\end{tabular}


Table 10

(Continued)

Pleading Standard

Univariate Regression Analysis

(Individual Judge Sample)

\begin{tabular}{|c|c|c|c|c|c|c|c|c|c|c|c|c|}
\hline \multirow[b]{2}{*}{ Variable } & \multicolumn{6}{|c|}{ Dichotomous Regressions } & \multicolumn{6}{|c|}{ Polytomous Regressions } \\
\hline & Model I & Model 2 & Model 3 & Model 4 & Model 5 & Model 6 & Model I & & Model 2 & & & Model 3 \\
\hline N.D.Cal & & $\begin{array}{l}2.055 \\
2.661\end{array}$ & & $\begin{array}{l}1.710+ \\
2.034\end{array}$ & & & & & $\begin{array}{r}-6.594 \\
-0.193 \\
1.413 \\
2.155\end{array}$ & & & \\
\hline D. Minn. & & & & & & & & & $\begin{array}{r}-1.455 \\
-0.067 \\
9.703 \\
11.622\end{array}$ & $A$ & $\begin{array}{l}\text { 1) } \\
\text { 2) } \\
\text { 3) } \\
\text { 4) }\end{array}$ & $\begin{array}{l}-5.194 \\
-0.110 \\
-4.238 \\
-0.099 \\
9.127 \\
9.449 \\
8.464 \\
3.856\end{array}$ \\
\hline N.D. Texas & & & & & & & & & $\begin{array}{r}1.891 \\
1.383 \\
-10.165 \\
-10.018\end{array}$ & & & \\
\hline RptJdg. & & & & & & & & & & & $\begin{array}{l}\text { 1) } \\
\text { 2) } \\
\text { 3) } \\
\text { 4) }\end{array}$ & $\begin{array}{l}1.946 \# \\
3.758 \\
2.113 \# \\
3.636 \\
1.466 * \\
2.379 \\
1.466 \\
2.761\end{array}$ \\
\hline ABA Rank & & & & & & & & & - & & $\begin{array}{l}\text { 1) } \\
\text { 2) } \\
\text { 3) } \\
\text { 4) }\end{array}$ & $\begin{array}{c}-1.099+ \\
1.975 \\
-0.605 \\
-0.953 \\
-0.894 \\
-1.393 \\
-0.606 \\
-1.059\end{array}$ \\
\hline Tech Intensity & & $\begin{array}{l}2.183 \\
2.124\end{array}+$ & & $\begin{array}{l}2.023 \\
2.005\end{array}$ & & & & & $\begin{array}{l}1.169 \\
1.003 \\
2.381 \\
2.577\end{array}$ & 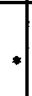 & & \\
\hline Tech/Judge & & $\begin{array}{l}1.907 \\
2.878\end{array}$ & & $\begin{array}{l}1.874 \\
2.583\end{array}$ & & & & & $\begin{array}{r}-0.334 \\
-0.384 \\
1.799 \\
3.084\end{array}$ & $\#$ & $\begin{array}{l}\text { 1) } \\
\text { 2) } \\
\text { 3) } \\
\text { 4) }\end{array}$ & $\begin{array}{l}1.841 \\
1.444 \\
1.193 \\
0.850 \\
2.679+ \\
2.054 \\
3.781 \\
3.125\end{array}$ \\
\hline $\begin{array}{c}\text { Aggregate } \\
\text { Docket }\end{array}$ & & & & $\begin{array}{l}-0.097+ \\
-1.961\end{array}$ & & $\begin{array}{ll}-0.202+ \\
-2.463\end{array}$ & 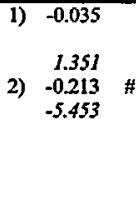 & 2 & $\begin{array}{r}-0.017 \\
-0.689 \\
-0.101 \\
-4.611\end{array}$ & $\#$ & $\begin{array}{l}\text { 1) } \\
\text { 2) } \\
\text { 3) } \\
\text { 4) }\end{array}$ & $\begin{array}{c}0.070 \\
\\
7.211 \\
0.036 \\
1.024 \\
-0.129 \\
-2.899 \\
0.003 \\
0.101\end{array}$ \\
\hline Docket per Judge & & & & & & & & & $\begin{array}{r}3.696 \\
2.436 \\
-0.026 \\
0.193\end{array}$ & 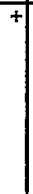 & $\begin{array}{l}\text { 1) } \\
\text { 2) } \\
\text { 3) } \\
\text { 4) }\end{array}$ & $\begin{array}{l}3.844 \\
1.706 \\
6.850 \\
2.918 \\
3.613 \\
1.424 \\
2.511 \\
1.059\end{array}$ \\
\hline
\end{tabular}




\section{Table 10}

(Continued)

Pleading Standard

Univariate Regression Analysis

(Individual Judge Sample)

\begin{tabular}{|c|c|c|c|c|c|c|c|c|c|}
\hline \multirow[b]{2}{*}{ Variable } & \multicolumn{6}{|c|}{ Dichotomous Regressions } & \multicolumn{3}{|c|}{ Polytomous Regressions } \\
\hline & Model 1 & Madel 2 & Model 3 & Model 4 & Model 5 & Madel 6 & Model 1 & Model 2 & Model 3 \\
\hline \begin{tabular}{|l|} 
SFCA per Judge \\
\end{tabular} & & $\begin{array}{l}0.349 \\
2.244\end{array}$ & & $\begin{array}{l}0.318 \\
2.19 I\end{array}$ & & & & $\begin{array}{ll}1) & 0.089 \\
& 0.545 \\
2) & 0.342 \\
& 2.728\end{array}$ & \begin{tabular}{ll|} 
1) & 0.102 \\
& 0.499 \\
2) & 0.167 \\
3) & 0.768 \\
& 0.306 \\
4) & 1.375 \\
& 0.505 \\
& 2.564
\end{tabular} \\
\hline Proce. & & & & & & & $\begin{array}{ll}\text { 1) } & 1.453 \\
\text { 2) } & 2.383 \\
& 0.201 \\
& 0.398\end{array}$ & & $\begin{array}{ll}1) & 0.087 \\
& 0.168 \\
\text { 2) } & 1.541+ \\
& 2.225 \\
\text { 3) } & 0.288 \\
& 0.479 \\
\text { 4) } & 0.624 \\
& 1.178\end{array}$ \\
\hline Corp. & & & & & & & & & \begin{tabular}{ll|}
$1)$ & $-1.4666+$ \\
& -2.291 \\
2) & -0.956 \\
& -1.159 \\
3) & $-1.718+$ \\
& -2.357 \\
4) & -1.678 * \\
& -2.631
\end{tabular} \\
\hline MultCase & & & & & & & & $\begin{array}{lr}\text { 1) } & 0.451 \\
& 1.975 \\
2) & -0.646 \quad \# \quad \text { \# } \\
& -2.874\end{array}$ & $\begin{array}{|cc|}1) & 7.430 \# \\
& 15.108 \\
\text { 2) } & 7.673 \# \\
& 15.529 \\
3) & 6.860 \# \\
& 10.657 \\
4) & 6.048 \# \\
& 12.308\end{array}$ \\
\hline Obsernation & 116 & 116 & 116 & 116 & 116 & 116 & 116 & 116 & 116 \\
\hline
\end{tabular}

Analysis of Tables 9 and 10 suggests several consistent patterns. First, Dichotomous Models 2, 3, and 4, and Polytomous Models 2 and 3 show the largest number of statistically significant univariate correlations, whereas the incidence of statistically significant correlations in Dichotomous Models 1,5 , and 6 and Polytomous Model 1 is relatively sparse. This pattern holds true for the All Observations and Individual Judge datasets. Dichotomous Models 5 and 6 and Polytomous Model 1 share the characteristic that they exclude minimalist observations from their analysis. The fact that all models that exclude minimalist observations are relatively sparse in terms of significant relationships can be the result of two factors. First, because minimalist observations are excluded, sample size for these regressions is smaller and statistical significance is more difficult to discern. Second, minimalist observations may be more correlated with our set of explanatory variables. A combination of both factors can also account for this observed pattern. The sparse correlations in Dichotomous Model 1 as opposed to the more frequent correlations in Dichotomous Model 2 suggest that the data are better able to 
explain the decision that a complaint fails even the lowest standard, whatever that might be, than the decision that a complaint is so well drafted that it satisfies the highest standard, whatever that might be.

Tables 9 and 10 also consistently suggest that the Northern District of California Cluster is robustly significant across model specifications and subdivisions of the dataset. The coefficients on the Northern District of California, Tech Intensity, Tech/Judge, and SFCA per Judge variables are all significant in at least four specifications in Table 9, and are most often significant beyond the one percent confidence interval. The coefficients on these variables are also uniformly positive, suggesting that these factors are correlated with a pro-defendant articulation of the pleading standard?235

Presence in the Northern District of Illinois is correlated with a proplaintiff result in four model specifications in the All Observations sample, but that variable has no statistically significant force in the Individual Judge sample. This pattern arises because of the presence of a small number of judges with repeatedly pro-plaintiff interpretations in the Northern District of Illinois sample. Once the multiple weighting on those rulings is removed in the Individual Judge sample, those correlations disappear.

The Aggregate Docket variable, which measures the absolute size of the civil docket in each court, is highly significant in five regression specifications in each of the two samples. The statistically significant coefficients are uniformly negative, suggesting that the larger the aggregate docket load in a court, the more likely that the court will adopt a pro-plaintiff interpretation of the "strong inference" standard. A closer look at the data, however, supports a different conclusion. The Aggregate Docket variable is heavily weighted by the "Other" district observation, which contains 86.05 percent of the total docket load in our sample (see Table 5). The Aggregate Docket variable can thus act as though it is an overweighted version of a binary variable that signifies presence in an "Other" district. Thus, the Aggregate Docket variable may be measuring a proclivity toward pro-plaintiff interpretations in less active districts rather than a true "docket management" effect. This alternative explanation is also more consistent with the observation that the Docket per Judge variable is not significant in Table 9 and that, in the two instances when it is significant in Table 10, it appears with a positive coefficient, suggesting that the busier the court, the more likely it is to exercise docket control by adopting a pro-defendant interpretation of the "strong inference" standard.

A judge's prior experience as a prosecutor is statistically significant in four model specifications in the All Observations sample and in two in the Individual Judge sample, but generally only at the five percent confidence

235. In Table 10, the Northern District of California, Tech. Intensity, Tech/Judge, and SFCA per Judge measures are statistically significant in at least three specifications. Again, all statistically significant correlations are positive. 
level. Every statistically significant coefficient is positive. This finding suggests that, contrary to our initial hypothesis, prior experience as a prosecutor predisposes a judge toward a pro-defendant interpretation of the pleading standard.

The MultCase variable is statistically significant in all polytomous regressions in Table 9 and in two of the three polytomous regressions reported in Table 10. The statistically significant variables are consistently positive, suggesting that the more frequently a judge in our sample has confronted the need to interpret the "strong inference" standard, the more likely the judge will be to adopt a pro-defendant interpretation. This finding is potentially consistent with both a "familiarity breeds skepticism" and a docket-control hypothesis.

The presidential variables do not, in our view, present compelling evidence in support of the political inclination hypothesis. Party affiliation of a nominating president is never statistically significant. No presidential variable is significant in more than two model specifications in either dataset. To the extent that one seeks to find meaning in the data, both datasets suggest that judges nominated by President Carter have a pro-plaintiff tendency, and the All Observations dataset suggests that judges nominated by President Reagan have a pro-defendant tendency. No other presidential variable is significant in more than one specification in either dataset.

\section{Outcome analysis.}

The analysis of the outcome in litigation is even more complex than the analysis of the interpretive standard and generates seven distinct categories. ${ }^{236}$ In order to construct a series of binary variables that supports dichotomous logistic regression techniques, we clustered these seven categories to generate four dichotomous dependent variables that conform to the definitions presented in Table 11. Each of these clusters is defined so that " 0 " represents the more pro-plaintiff result and " 1 " represents the more pro-defendant result. Accordingly, a positive (negative) coefficient on an explanatory variable would represent a correlation with a pro-defendant (pro-plaintiff) outcome. The structure of this categorization is illustrated in Figure 2. 
Table 11

Definition of Dichotomous and Polytomous Dependent Variables for Outcome Regressions

\begin{tabular}{|c|c|c|}
\hline \multirow{3}{*}{\begin{tabular}{|l|}
$\begin{array}{l}\text { Dependent } \\
\text { Variable }\end{array}$ \\
Dichot 1 \\
\end{tabular}} & \multicolumn{2}{|c|}{ Definition } \\
\hline & $=0$ & if motion to dismiss is denied in its entirety \\
\hline & $=1$ & otherwise \\
\hline \multirow[t]{2}{*}{ Dichot 2} & $=0$ & or \\
\hline & $=1$ & if motion is granted in its entirety with prejudice \\
\hline \multirow[t]{2}{*}{ Dichot 3} & $=0$ & if motion is denied in entirety, or if all portions dismissed are dismissed without prejudice \\
\hline & $=1$ & otherwise \\
\hline \multirow[t]{2}{*}{ Dichot 4} & $=0$ & or \\
\hline & $=1$ & if motion is granted with prejudice in entirety, or granted in part and all parts are granted with prejudice \\
\hline \multirow[t]{3}{*}{ Polyt I } & $=0$ & if motion to dismiss is denied in its entirety \\
\hline & $=1$ & if motion is granted in whole or in part, but without prejudice as to any part \\
\hline & $=2$ & otherwise \\
\hline \multirow[t]{3}{*}{ Polyt 2} & $=0$ & if motion is denied or granted in part or in whole, but without prejudice \\
\hline & $=1$ & if motion is granted in part or entirety, but with prejudice as to some portions \\
\hline & $=2$ & otherwise \\
\hline \multirow[t]{5}{*}{ Polyt 3} & $=0$ & if motion is denied in its entirety \\
\hline & $=1$ & if motion is denied in part or granted, but without prejudice as to any part \\
\hline & $=2$ & if motion is granted in part or in its entirety, but with prejudice only with respect to some portion of the motion \\
\hline & $=3$ & if motion is granted in part, and with prejudice as to all portions granted \\
\hline & $=4$ & if motion is granted in its entirety and with prejudice \\
\hline
\end{tabular}




\section{Figure 2}

Schematic Representation of the Definition of Dichotomous and Polytomous Dependent Variables for Outcome Regressions

\begin{tabular}{|c|c|c|c|c|c|c|c|}
\hline Definition of & & Without Prejudi & ce as to Any Part & With Prejudice & as to Some Parts & With Prejudice & as to All Parts \\
\hline $\begin{array}{l}\text { Dependent } \\
\text { Variable }\end{array}$ & $\begin{array}{l}\text { Motion Denied in } \\
\text { Entirety }\end{array}$ & $\begin{array}{c}\text { Motion Granted } \\
\text { in Part }\end{array}$ & $\begin{array}{l}\text { Motion Granted } \\
\text { in Entirety }\end{array}$ & $\begin{array}{c}\begin{array}{c}\text { Motion Granted } \\
\text { in Part }\end{array} \\
\text {. }\end{array}$ & $\begin{array}{l}\text { Motion Granted } \\
\text { in Entirety }\end{array}$ & $\begin{array}{c}\text { Motion Granted } \\
\text { in Part }\end{array}$ & $\begin{array}{l}\text { Motion Granted } \\
\text { in Entirety }\end{array}$ \\
\hline Dichot 1 & & & & & & & \\
\hline Dichot 2 & & & e & & & & 1 \\
\hline Dichot 3 & & 8 & & & $\overline{1}$ & & \\
\hline Dichot 4 & & & $\theta$ & & & 1 & \\
\hline Polyt 1 & 0 & & $\overline{1}$ & & $\overline{2}$ & & \\
\hline Polyt 2 & & 0 & & & i & 2 & 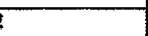 \\
\hline Polyt 3 & 0 & & 1 & & 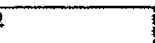 & 3 & 4 \\
\hline
\end{tabular}

Here, Dichot $1=0$ if the motion to dismiss is denied in its entirety and equals 1 otherwise. Dichot $2=1$ if the motion to dismiss is granted in its entirety with prejudice, and equals 0 otherwise. Accordingly, these two dependent variables test for the most extreme outcomes. Dichot $3=0$ if the motion is denied in its entirety or if granted without prejudice as to every part, and equals 1 otherwise. Dichot $4=0$ unless the motion is granted in part or in its entirety, and with prejudice.

Polyt $1=0$ if the motion is denied in its entirety, equals 1 if it is granted without prejudice as to any portion, and equals 2 otherwise. Polyt $2=0$ if the motion is denied or granted without prejudice as to any part, equals 1 if it is granted in part or in its entirety but only portions with prejudice, and equals 2 if the motion is granted in its entirety or in part but with prejudice as to all portions. Polyt $3=0$ if the motion is denied, equals 1 if the motion is granted in whole or in part but without prejudice as to any part, equals 2 if it is granted with prejudice as to some parts, equals 3 if the motion is granted and with prejudice as to all parts, and equals 4 if the motion is granted in its entirety with prejudice.

Table 12 reports univariate regression results for the All Observations 
sample. ${ }^{237}$ Its findings are in many respects quite consistent with the results reported in the interpretive standards univariate regressions. In particular, the Northern District of California Cluster, which here also contains Tech Intensity and Tech/Judge, is significant in six of seven of the regression specifications, while SFCA per Judge is significant in four regressions and SFCA Docket in three. All of the statistically significant coefficients are positive, suggesting that the components of the cluster are again all correlated with a more prodefendant ruling on the motion to dismiss.

The RptJdg variable is also statistically significant in six of seven regression specifications, and the coefficients are all positive. This pattern strongly suggests that judges who rule in more than one decision in our database are more likely to rule in defendants' favor than judges who are represented only once in the database.

Presidential appointment and party affiliation variables are again lightly represented. Only the Bush variable is statistically significant in two regressions, and it has a positive coefficient in both.

Table 12

Ruling on Motion to Dismiss

Univariate Regression Analysis

(All Observations)

\begin{tabular}{|c|c|c|c|c|c|c|c|c|c|c|}
\hline \multirow[b]{2}{*}{ Variable } & \multicolumn{4}{|c|}{ Dichotomous Regressions } & \multicolumn{6}{|c|}{ Polyomous Regressions } \\
\hline & Model 1 & Model 2 & Model 3 & Model 4 & & del 1 & & Model 2 & & $\operatorname{odcl} 3$ \\
\hline Bush & & & & & & $\begin{array}{l}.221 \\
2.202 \\
0.167 \\
0.251\end{array}$ & & & 1) & $\begin{array}{c}1.222+ \\
2.203 \\
0.263 \\
0.227 \\
-6.937 \\
-0.212 \\
0.471 \\
0.661\end{array}$ \\
\hline N.D.Cal. & $\begin{array}{l}2.394 \\
2.350\end{array}$ & $\begin{array}{l}1.154 \\
2.189\end{array}+$ & & $\begin{array}{l}1.223 \\
2.437\end{array}$ & $\begin{array}{l}\text { 1) } \\
\text { 2) }\end{array}$ & $\begin{array}{l}2.271 \\
2.119 \\
2.533 \\
2.359\end{array}$ & 1) & $\begin{array}{c}-7.300 \\
-0.173 \\
1.143 \\
2.273\end{array}+$ & $\begin{array}{l}\text { 1) } \\
\text { 2) } \\
\text { 3) }\end{array}$ & $\begin{array}{c}2.275+ \\
2.119 \\
-4.431 \\
-0.193 \\
2.648+ \\
2.063 \\
2.841 \\
2.583\end{array}$ \\
\hline N.D. Ill. & $\begin{array}{l}-1.311 \\
-2.017\end{array}$ & & & & & & & & & \\
\hline Tech Intensity & & $\begin{array}{l}1.922+ \\
2.449\end{array}$ & $\begin{array}{l}1.485 \\
2.069\end{array}$ & $\begin{array}{l}2.065 \\
2.806\end{array}$ & $\begin{array}{l}\text { 1) } \\
\text { 2) }\end{array}$ & $\begin{array}{l}1.100 \\
1.145 \\
2.118 \\
2.248\end{array}$ & 1) & $\begin{array}{r}-3.164 \\
-0.876 \\
1.946 \\
2.632\end{array}$ & 2) & $\begin{array}{c}1.103 \\
1.147 \\
-2.536 \\
-0.692 \\
2.419 * \\
1.726 \\
2.634 \\
2.599\end{array}$ \\
\hline
\end{tabular}

237. There is no corresponding analysis for the Individual Judge sample because it is impossible to assign a single outcome variable to each judge. 
Table 12

(Continued)

Ruling on Motion to Dismiss

Univariate Regression Analysis

(All Observations)

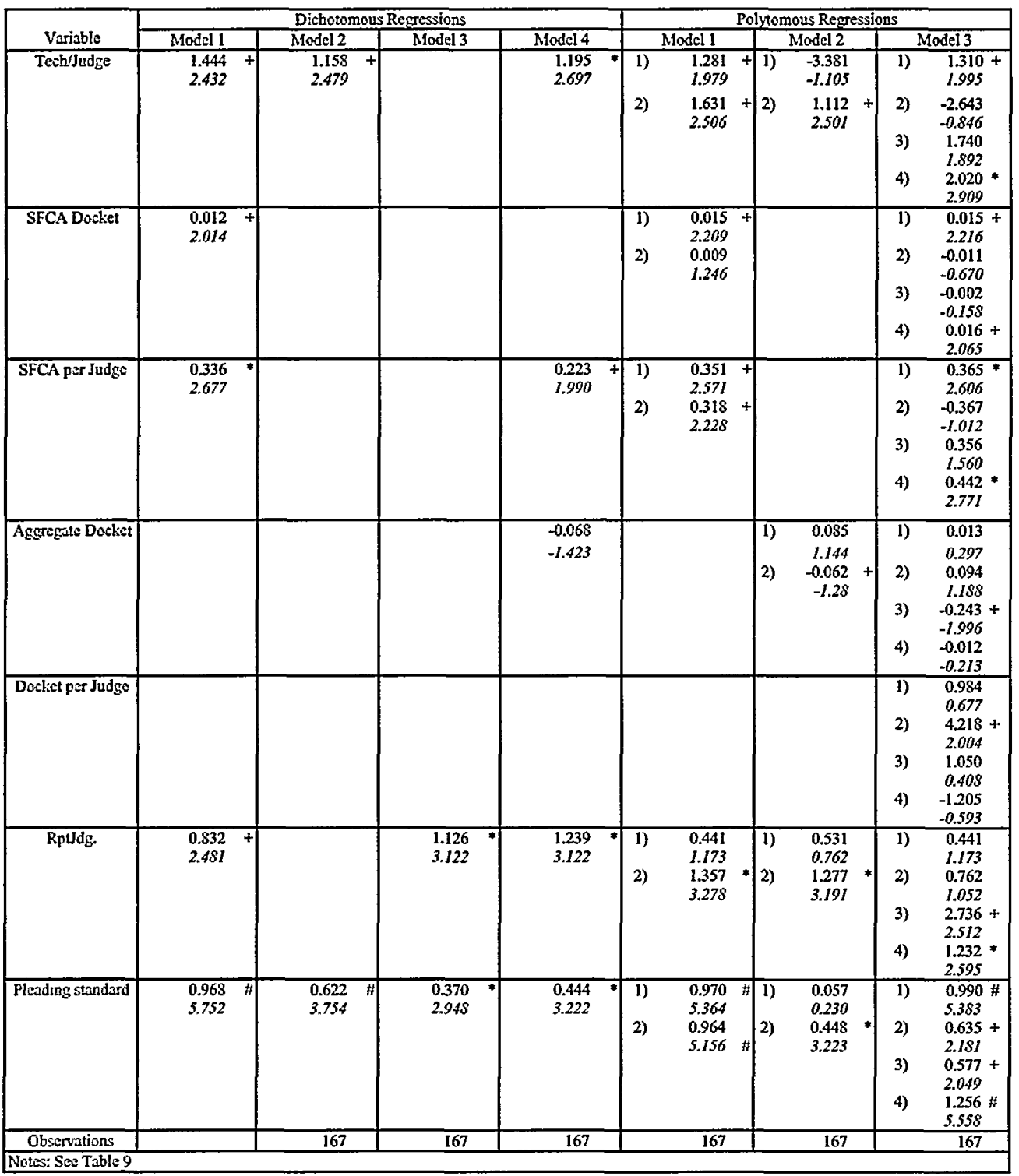


Table 13

Ruling on Motion to Dismiss

Univariate Regression Analysis

(Excluding Minimalist Decisions)

\begin{tabular}{|c|c|c|c|c|c|c|c|c|c|}
\hline \multirow{3}{*}{$\begin{array}{c}\text { Variable } \\
\text { Clinton }\end{array}$} & \multirow{2}{*}{\multicolumn{4}{|c|}{$\begin{array}{l}\text { Dichotomous Regressions } \\
\begin{array}{|l|r|}\text { Model 2 } & \text { Mode1 } 3\end{array}\end{array}$}} & \multicolumn{5}{|c|}{ Polytomous Regressions } \\
\hline & Model 1 & & Mode1 3 & Model 4 & & del 1 & & odel 2 & Madel 3 \\
\hline & & & & $\begin{array}{l}-1.865 \\
-2.433\end{array}$ & & & 1) & \begin{tabular}{c|}
1.226 \\
1.755 \\
$-1.770 \quad \#$ \\
-4.278
\end{tabular} & $\begin{array}{|ll|}1) & 0.248 \\
\text { 2) } & 0.638 \\
& 1.347 \\
\text { 3) } & -1.858 \\
& -1.543 \\
\text { 4) } & -1.417 \\
& -3.744 \\
& -3.604 \\
\end{array}$ \\
\hline $\begin{array}{ll}\text { Bush } \\
\text { h }\end{array}$ & & & & & & & 1) & \begin{tabular}{c|}
-6.855 \\
-6.296 \\
0.116 \\
0.199 \\
\end{tabular} & 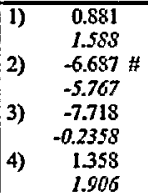 \\
\hline Reagan & & & & & & $\begin{array}{l}-1.005 \\
-2.524 \\
0.211 \\
0.526\end{array}$ & 1) & $\begin{array}{c}-0.041 \\
-0.056 \\
0.835 \\
2.217\end{array}+$ & $\begin{array}{lc}1) & -1.005+ \\
\text { 2) } & -2.524 \\
& -0.482 \\
& -0.634 \\
\text { 3) } & 0.617 \\
& 0.578 \\
\text { 4) } & 0.211 \\
& 0.450\end{array}$ \\
\hline Carter & & & & & & $\begin{array}{l}1.563+ \\
1.986 \\
0.315 \\
0.337\end{array}$ & & & 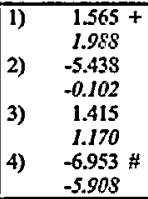 \\
\hline Johnson & & & & & & $\begin{array}{l}-8.164 \quad \# \\
-5.724 \\
0.315 \\
0.825\end{array}$ & & & \begin{tabular}{|ll} 
1) & $-9.873 ~ \#$ \\
2) & -6.924 \\
& -9.150 \\
& -0.170 \\
3) & -8.087 \\
& -0.131 \\
4) & 1.214 \\
& 0.847
\end{tabular} \\
\hline \begin{tabular}{|c|} 
Democrat \\
\end{tabular} & & & & $\begin{array}{l}-1.377 \\
-2.311\end{array}$ & & & & \begin{tabular}{|c|}
0.885 \\
1.272 \\
$-1.312 \quad \#$ \\
-3.399
\end{tabular} & $\begin{array}{ll}\text { 1) } & 0.485 \\
\text { 2) } & 1.295 \\
\text { 3) } & 1.1251 \\
\text { 3) } & -0.959 \\
& -1.149 \\
\text { 4) } & -1.182+ \\
& -2.550\end{array}$ \\
\hline Republican & & & & $\begin{array}{l}1.377 \\
2.311\end{array}$ & & & & $\begin{array}{c}-0.885 \\
-1.272 \\
1.312 \\
3.399\end{array}$ & $\begin{array}{ll}\text { 1) } & -0.485 \\
\text { 2) } & -1.295 \\
\text { 2) } & -1.121 \\
& -1.552 \\
\text { 3) } & 0.959 \\
& 1.149 \\
\text { 4) } & 1.182+ \\
& 2.550\end{array}$ \\
\hline S.D.N.Y. & & & & & & & & $\begin{array}{c}0.016 \\
0.015 \\
-8.835 \\
-13.582\end{array}$ & $\begin{array}{|ll|}\text { 1) } & 0.924 \\
\text { 2) } & 1.790 \\
& 0.532 \\
& 0.468 \\
3) & -8.363 \\
& -0.155 \\
\text { 4) } & -8.452 \text { \# } \\
& -11.574 \\
\end{array}$ \\
\hline
\end{tabular}


Table 13

(Continued)

Ruling on Motion to Dismiss

Univariate Regression Analysis

(Excluding Minimalist Decisions)

\begin{tabular}{|c|c|c|c|c|c|c|c|c|c|c|c|}
\hline \multirow[b]{2}{*}{ Variable } & \multicolumn{4}{|c|}{ Dichotomous Regressions } & \multicolumn{7}{|c|}{ Polytomous Regressions } \\
\hline & Model I & Mrodel 2 & Model 3 & Model 4 & & Model 1 & & Madel 2 & & & Model 3 \\
\hline N.D. Cal. & & & & & & & $\begin{array}{l}\text { 1) } \\
\text { 2) }\end{array}$ & $\begin{array}{r}-5.807 \\
-0.138 \\
1.724 \\
3.430 \\
\end{array}$ & & & \\
\hline E.D. $\mathrm{Pa}$. & & & & & & & {$\left[\begin{array}{l}1) \\
\text { 2) }\end{array}\right.$} & $\begin{array}{l}-6.071 \\
-5.411 \\
-0.433 \\
-0.533\end{array}$ & \# & $\begin{array}{l}\text { 1) } \\
\text { 2) } \\
\text { 3) }\end{array}$ & $\begin{array}{c}0.524 \\
0.694 \\
-6.676 \\
-5.494 \\
-8.067 \\
-0.174 \\
0.493 \\
0.523\end{array}$ \\
\hline C.D. Cal & & & & & & $\begin{array}{r}0.087 \\
0.094 \\
-8.248 \\
-8.827\end{array}$ & $\begin{array}{l}\text { 1) } \\
\text { 2) }\end{array}$ & $\begin{array}{r}-7.016 \\
-0.110 \\
-8.725 \\
-10.176\end{array}$ & \# & $\begin{array}{l}\text { 1) } \\
\text { 2) } \\
\text { 3) }\end{array}$ & $\begin{array}{l}0.087 \\
0.093 \\
-6.930 \\
-0.115 \\
-8.629 \\
-0.134 \\
-9.073 \# \\
-9.631\end{array}$ \\
\hline D. Mínn. & & & & & & & & & & $\begin{array}{l}\text { 1) } \\
\text { 2) } \\
\text { 3) }\end{array}$ & $\begin{array}{c}0.086 \\
0.092 \\
-5.259 \\
-0.086 \\
1.415 \\
1.170 \\
-6.995 \\
-7.425\end{array}$ \\
\hline Tech Intensity & & & & $\begin{array}{l}2.278+ \\
2.113\end{array}$ & & & $\begin{array}{l}\text { 1) } \\
\text { 2) }\end{array}$ & $\begin{array}{r}-1.987 \\
-0.550 \\
2.179 \\
2.946 \\
\end{array}$ & * & & \\
\hline Tech/Judge & & & & & & & 1) & $\begin{array}{r}-2.222 \\
-0.726 \\
11.253 \\
2.817\end{array}$ & * & & \\
\hline SFCA Docket & & & & & & & $\begin{array}{l}\text { 1) } \\
\text { 2) }\end{array}$ & $\begin{array}{l}-0.011 \\
-0.745 \\
-0.012 \\
-1.989\end{array}$ & + & & \\
\hline Aggregate Docket & & & & $\begin{array}{l}-0.182 \\
-2.456\end{array}$ & & & 1) & $\begin{array}{r}0.108 \\
1.263 \\
-0.175 \\
-2.337\end{array}$ & * & 2) & $\begin{array}{l}0.007 \\
0.128 \\
0.112 \\
1.246 \\
-0.280 * \\
-2.212 \\
-0.105 \\
-1.155\end{array}$ \\
\hline Rptdg. & & & $\begin{array}{l}1.107 \\
2.367\end{array}$ & $\begin{array}{l}1.313 \\
2.477\end{array}$ & & $\begin{array}{l}0.367 \\
0.977 \\
1.286 \\
3.106\end{array}$ & $\begin{array}{l}\text { 1) } \\
\text { 2) }\end{array}$ & $\begin{array}{l}0.360 \\
0.517 \\
1.341 \\
3.351\end{array}$ & $\#$ & 1) & $\begin{array}{l}0.367 \\
0.977 \\
0.539 \\
0.744 \\
2.736+ \\
2.512 \\
0.876 \\
1.844\end{array}$ \\
\hline Corp. & & & & & & & 1) & $\begin{array}{l}7.735 \\
7.151 \\
0.387 \\
0.917\end{array}$ & \# & 1) & $\begin{array}{c}-0.109 \\
-0.255 \\
7.409 \\
6.695 \\
0.217 \\
0.255 \\
0.441 \\
0.848 \\
\end{array}$ \\
\hline
\end{tabular}


Table 13

(Continued)

Ruling on Motion to Dismiss

Univariate Regression Analysis

(Excluding Minimalist Decisions)

\begin{tabular}{|c|c|c|c|c|c|c|c|c|c|}
\hline & \multirow{2}{*}{\multicolumn{4}{|c|}{ 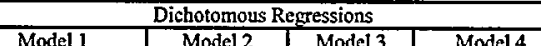 }} & \multirow{2}{*}{\multicolumn{5}{|c|}{ Polytomous Regressions }} \\
\hline Variable & & Model 2 & Model 3 & Model4 & & & & & $\begin{array}{l}\text { Model33 } \\
\end{array}$ \\
\hline Public Int. & & & & & & $\left(\begin{array}{l}1) \\
22\end{array}\right.$ & $\begin{array}{l}-6.855 \\
-6.242 \\
0.116 \\
0.238\end{array}$ & & $\begin{array}{c}-0.161 \\
-0.279 \\
-7.626 \# \\
-0.676 \\
0.501 \\
0.071 \\
-0.511 \\
-0.859\end{array}$ \\
\hline ABA Rank & & & & & $\begin{array}{|lr|}\text { 1) } & 0.956 \\
\text { 2) } & -.461 \\
& -0.105 \\
& -0.267 \\
\end{array}$ & & & & $\begin{array}{c}0.955+ \\
2.2461 \\
-0.101 \\
-0.139 \\
-0.139 \\
-0.105 \\
-0.153 \\
-0.05 \\
0.231\end{array}$ \\
\hline Pleading Standard & & & & & & (1) & $\begin{array}{r}-8.328 \\
>20 \\
0.254 \\
1.827\end{array}$ & & $\begin{array}{c}0.267 \\
1.455 \\
-6.756 \# \\
>220 \\
0.374 \\
1.327 \\
0.397 \\
1.758 \\
\end{array}$ \\
\hline $\begin{array}{l}\text { Observations } \\
\text { Notes: See Table } 9\end{array}$ & 101 & 101 & 101 & 101 & 101 & & 101 & & 101 \\
\hline
\end{tabular}

Table 12 also reports results for a "Pleading standard" explanatory variable that assumes a value of one through five, depending on the interpretative standard characteristic of that judge, as described in our five-way categorization of interpretive standards. ${ }^{238}$ Although this variable is significant in every regression, these correlations should be greatly discounted because the Pleading standard variable is constructed in a manner that bears an inherent correlation with the outcome variable: every value of one (Satisfies Highest) for the Pleading variable will correlate with the motion to be denied and every value of five (Fails Lowest) for the Pleading variable will correlate with the motion being granted. We present these data in Table 12 primarily for purposes of contrast with the results presented in Table 13.

Table 13 repeats the same analysis as in Table 12, but on a sample that excludes all minimalist observations (Fails Lowest or Satisfies Highest) on the theory that only cases in which a judge actually resolves the interpretative dilemma can be viewed as providing useful information about the relationship between interpretive conduct and the model's explanatory variables. Here, Models 1 and 2 provide no useful information because, by construction, they cannot operate without the inclusion of minimalist observations. Dichotomous Models 3 and 4 are now very sparse, and explanatory relationships are most 
apparent in the polytomous regressions.

The RptIdg variable is now significant with a positive coefficient in all five operative regressions. This again suggests that the more frequently a judge rules on cases in our sample, the more likely the ruling will be pro-defendant.

The Northern District of California Cluster, however, loses most of its explanatory force. This pattern suggests that judges in the Northern District frequently express pro-defendant results by deciding that cases are so poorly pled that they fail the weakest interpretation of the standard.

Political variables and a new set of district court variables now appear to be consistently significant in the polytomous regressions. In particular, the Democrat variable appears with a negative coefficient in three of the five operative regressions, indicating that judges nominated by Democratic presidents who take a stand on the interpretative issue tend to rule in favor of plaintiffs. The results for the Republican variable are identical, but with the signs on the coefficients reversed, indicating a precisely equal and opposite tendency for judges nominated by Republican presidents to take a prodefendant stance when they actually take a position on the interpretive issue.239 This pattern suggests a political inclination in the resolution of motions, even if there is no political inclination in the selection of an interpretive standard, provided that the data are viewed from a univariate perspective.

The results for individual presidents are not as clean. The signs on all statistically significant Clinton and Johnson coefficients are negative, indicating a pro-plaintiff tropism for these Democratic presidents. There is, however, a positive coefficient on two of the statistically significant Carter coefficients, but one of those is offset by a far more powerful negative coefficient suggesting a strong aversion to the most pro-defendant ruling in Polytomous Model 3. On the Republican side, Bush and Reagan coefficients also occasionally appear as negative.

As for district court effects, the Central District of California now appears to avoid strongly the most pro-defendant outcomes in three of the model specifications, and the Southern District of New York displays the same tendency in two specifications. The Eastern District of Pennsylvania appears to avoid intermediate results in two specifications, while the Northern District of California is the only court to display a statistically significant tendency to adopt the most pro-defendant outcomes.

The Aggregate Docket variable is now significant in four of the five operative regressions, and always with a negative coefficient. However, for reasons already explained, this correlation reflects a tendency among the "Other" districts to adopt pro-plaintiff rulings rather than a docket effect. ${ }^{240}$

239. The result is a direct consequence of the fact that the Democrat and Republican variables are perfectly negatively correlated.

240. See supra p. 712. 
The Docket per Judge variable, which is significant in only one regression, and there with a positive coefficient, is again consistent with our prior interpretation of the data. ${ }^{241}$

Individual judicial characteristics, such as corporate and public interest background and ABA ranking, now appear for the first time to be significant with any discernable pattern. The statistically significant coefficients on the Corp variable are both positive, while the statistically significant coefficients on the Public Int variable are both negative. This pattern suggests, as initially hypothesized, a tendency by judges with corporate backgrounds to rule in favor of defendants and a tendency by judges with public interest backgrounds to rule in favor of plaintiffs. This tendency, it should be emphasized, arises even though there is no corresponding pattern in the articulation of interpretive standards. The ABA Rank variable appears with a statistically significant positive and negative coefficient in two regressions, and we draw no inference from that conflicting pattern. The RptJdg variable is statistically significant in five regression specifications and always with a positive coefficient. This pattern, which is identical to the pattern observed in the interpretive standard regressions, suggests that the more frequently judges in our sample rule on motions the more likely they are to rule in defendant's favor. The univariate results are thus consistent: The more frequently judges confront the question, the more likely they are to adopt pro-defendant interpretations of the "strong inference" standard and the more likely they are to rule in defendants' favor.

The Pleading standard variable is significant now in only two specifications, and both times indicating a strong negative tendency toward an intermediate form of ruling; that is, the stricter the pleading standard, the more likely it is that a motion to dismiss will be granted or denied in its entirety. As Table 3 illustrates, however, there are only nine such rulings in the database, and it is difficult to conclude from this observation that the selection of an interpretive standard has a powerful correlation with the resolution of the motion to dismiss when the court avoids a minimalist interpretive style. These findings do not, in our view, strongly support the conclusion that the selection of an interpretive standard has a significant influence on the outcome of the litigation.

\section{Multivariate Analysis}

In addition to these univariate analyses, we conducted a series of multivariate forward stepwise regressions in order to identify the subsets of variables that are statistically significant in explaining the pattern of variation in the selection of the interpretive standard and in the resolution of the

241. Id. 
underlying motions to dismiss. ${ }^{242}$ We also applied these techniques to determine whether the selection of a pleading standard is statistically significant as an explanatory variable in the resolution of the motion to dismiss.

In running a forward stepwise regression, our algorithm begins by searching for the single explanatory variable that generates the highest correlation with the given dependent variable. Our algorithm then continues to add individual explanatory variables, in a sequence of descending contribution to the statistical significance of the overall regression equation, until the addition of the next most significant explanatory variable no longer contributes to the explanatory power of the overall regression. In many cases, the addition of a new variable will contribute to the overall statistical significance of the equation, but because of a correlation with a previously included explanatory variable, the previously included variable loses its statistical significance on an individual basis. Under those circumstances, we do not omit those insignificant variables (which were significant in earlier stepwise iterations) from our reported results. Accordingly, our reported results include statistically insignificant coefficients on variables that were statistically significant in earlier stepwise iterations of the model.

\section{Interpretive standard regressions.}

Tables 14 and 15 report the results of multivariate forward stepwise regressions that search for the set of explanatory variables most significantly related to the selection of an interpretive standard. Table 14 reports results for regressions run on the All Observations dataset. Table 15 reports results for the same regressions run on the smaller Individual Judge sample. The linear combination of the coefficients reported in each regression and the variables are $\log$-likelihood ratios. ${ }^{243}$ The tables report the coefficients of all variables that are statistically significant at any stage of the forward stepwise regression procedure, even if they are not statistically significant at the conclusion of the process. In the polytomous regression, each coefficient reports the loglikelihood of the corresponding sequential categorization relative to the baseline dependent variable categorization.

Evidently, given the size of Tables 14 and 15, a large number of explanatory variables display statistical significance at some point in the stepwise regression procedure. If, however, we focus attention only on variables that are statistically significant in at least three of the final stages of

242. For a description of forward stepwise regression techniques and for an explanation why we did not rely on backward stepwise techniques, see the Statistical Appendix at http://law.stanford.edu/lawreview/gp2001/.

243. For an explanation of log-likelihood ratios, see the Statistical Appendix at http://law.stanford.edu/lawreview/gp2001/. 
the stepwise regression specifications in either sample, a relatively focused and coherent story emerges.

Presidential variables are statistically significant, with the Carter, Ford, and Nixon variables displaying the most consistent significance. The coefficients are dominantly negative, indicating that judges appointed by these three presidents tend to adopt pro-plaintiff interpretations, even though two of the presidents are Republican and one is a Democrat. This pattern suggests that the identity of the nominating president, rather than the simple party affiliation, may be the salient explanatory factor. This pattern is also consistent with the hypothesis that more senior judges are more likely to adopt pro-plaintiff perspectives. Although the Clinton, Bush, and Reagan variables are significant only in the All Observations sample, and then only in a small number of the final stages of the regression, the Clinton coefficient is uniformly negative and the Bush and Reagan coefficients are uniformly positive. This pattern is consistent with the political hypothesis that Clinton nominees are likely to be pro-plaintiff and Bush and Reagan nominees are likely to be pro-defendant. The inference is weak, however, because it is so contingent on the specifications of the dependent variable and on the sample used to test the hypotheses.

Beyond these observations, the situation becomes more complex. The district court in which the case is decided can be a statistically significant factor. In the All Observations sample, the Northern District of California and District of Minnesota variables are statistically significant in six and five regression specifications respectively. Each variable displays dominantly positive coefficients, suggesting pro-defendant tendencies. In the Individual Judge sample, however, the Northern District of California variable is significant in only one specification, while the District of Minnesota variable retains significance in four specifications, again with dominantly positive coefficients. This pattern suggests that repeated decisions by a small number of judges in our sample are responsible for driving the apparent significance of the Northern District of California variable in the All Observations sample. Moreover, because Minnesota decisions account for less than five percent of either sample, the practical significance of that variable is limited.

The size of the Docket per Judge variable is statistically significant in three specifications in the Individual Judge sample. The coefficients on the Docket per Judge variable are uniformly positive. At the same time, the Tech/Judge variable is significant and positive in three specifications in the Individual Judge sample, while the RptJdg variable is significant and negative in four specifications.

Viewed independently, these findings provide support for a "docket control" hypothesis suggesting that busier courts, measured on a docket-perjudge basis, are more likely to adopt a pro-defendant interpretation of the statute. These findings also suggest that the more frequently judges view 
technology cases, the more likely they are to adopt pro-defendant interpretations of the statute. At the same time, however, the data do not support the "familiarity breeds skepticism" argument because the significant coefficients on the RptJdg variable are negative.

This interpretation of these coefficients is, however, called into question once we recognize that in three of the four regression models in which the RptJdg variable is significant and negative, the Docket per Judge and/or the Tech/Judge variables are positive and significant. The opposite signs on the RptJdg variable on the one hand, and on the Docket per Judge and Tech/Judge variables on the other, may thus reflect an interaction effect. If so, the "docket control" and "technology exposure" hypotheses may be correct, but the model may exaggerate the significance of those variables in cases involving judges who issue more than one decision in our sample.

Table 14

Pleading Standard

Multivariate Forward Stepwise Regression Analysis

(All Observations)

\begin{tabular}{|c|c|c|c|c|c|c|c|c|c|}
\hline \multirow[b]{2}{*}{ Variable } & \multicolumn{6}{|c|}{ Dichotomous Regressions } & \multicolumn{3}{|c|}{ Polytomous Regressions } \\
\hline & Model 1 & Model 2 & Model 3 & Model 4 & Model 5 & Model 6 & Model I & Model 2 & Model 3 \\
\hline Clinton & & $\begin{array}{l}-0.776 \\
-1.710\end{array}$ & & $\begin{array}{l}-1.005 \\
-2.340\end{array}$ & & & & $\begin{array}{r}0.842 \\
1.547 \\
-0.822 \\
-1.785\end{array}$ & $\begin{array}{l}-1.134 \\
-1.771 \\
-0.057 \\
-0.079 \\
-1.594 \\
-2.081 \\
-1.604 \\
-2.331\end{array}+$ \\
\hline Bush & & & & & $\begin{array}{l}0.301 \\
0.421 \\
\end{array}$ & $\begin{array}{l}2.155 \\
2.050 \\
\end{array}$ & & & \\
\hline Reagan & $\begin{array}{l}1.433 \\
2.120\end{array}+$ & & & & & & & & \\
\hline Carter & & $\begin{array}{l}-2.957 \\
-1.993\end{array}$ & $\begin{array}{l}-4.743 \\
-2.693\end{array}$ & $\begin{array}{l}-3.990 \\
-2.565\end{array}$ & $\begin{array}{c}-25.707 \\
>20\end{array}$ & $\begin{array}{r}-23.394 \\
-0.166\end{array}$ & $\begin{array}{r}-25.975 \quad \# \\
>20 \\
-50.366 \\
>20\end{array}$ & $\begin{array}{r}-106.493 \\
>20 \\
4.386 \\
-2.600\end{array}+$ & \begin{tabular}{rr|}
-0.408 \\
-0.425 \\
$-25.116 \quad$ \\
$>20$ \\
-35.800 \\
$>20$ & $\#$ \\
-3.953 & + \\
-2.174 & \\
\end{tabular} \\
\hline Ford & & & & $\begin{array}{l}-8.352 \\
-0.154\end{array}$ & & & $\begin{array}{r}60.076 \quad \# \\
>20 \\
-20.497 \\
>20\end{array}$ & $\begin{array}{r}164.206 \quad \# \\
>20 \\
-41.124 \quad \# \\
>20\end{array}$ & \begin{tabular}{rr|}
-11.955 & $\#$ \\
$>20$ & \\
37.660 & $\#$ \\
$>20$ & $\#$ \\
-6.728 & $\#$ \\
$>20$ & \\
-10.642 & $\#$ \\
$>20$ & $\#$
\end{tabular} \\
\hline
\end{tabular}


Table 14

(Continued)

Pleading Standard

Multivariate Forward Stepwise Regression Analysis

(All Observations)

\begin{tabular}{|c|c|c|c|c|c|c|c|c|c|}
\hline \multirow[b]{2}{*}{ Variable } & \multicolumn{6}{|c|}{ Dichotomous Regressions } & \multicolumn{3}{|c|}{ Polytomous Regressions } \\
\hline & Model 1 & Model 2 & Model 3 & Model 4 & Model 5 & Model 6 & Model 1 & Model 2 & Model 3 \\
\hline Nixon & & & $\begin{array}{l}-2.530+ \\
-2.260\end{array}$ & $\begin{array}{l}-1.337 \\
-1.482\end{array}$ & $\begin{array}{r}-26.047 \\
>20\end{array}$ & $\begin{array}{r}-26.572 \\
-1.067\end{array}$ & $\begin{aligned}-34.087 & \# \\
>20 & \\
-63.757 & \# \\
>20 & \#\end{aligned}$ & & $\begin{array}{r}-0.023 \\
-0.019 \\
-40.544 \\
>20 \\
-38.585 \\
>20 \\
-1.996 \\
-1.234\end{array}$ \\
\hline Johnson & & & & & $\begin{array}{l}1.246 \\
0.747\end{array}$ & $\begin{array}{l}4.650+ \\
2.214\end{array}$ & & & \\
\hline Other & $\begin{array}{l}7.838 \\
0.196\end{array}$ & & & & & & \begin{tabular}{rl|}
-27.994 & $\#$ \\
$>20$ & \\
3.042 & $\#$ \\
$>20$ &
\end{tabular} & & \\
\hline Magistrate & $\begin{array}{l}-9.494 \\
-0.238\end{array}$ & $\begin{array}{l}-9.512 \\
-0.105\end{array}$ & & & \begin{tabular}{ll|}
24.135 & $\#$ \\
$>30$ &
\end{tabular} & $\begin{array}{r}27.783 \\
>20\end{array}$ & & & $\begin{array}{r}-36.810 \# \\
>20 \\
-32.099 \quad \# \\
>20 \\
-1.020 \\
-0.976 \\
-37.985 \\
>20\end{array}$ \\
\hline N.D. Cal. & & $\begin{array}{l}3.710 \quad \# \\
4.785\end{array}$ & & $\begin{array}{l}4.209 \quad \# \\
4.102\end{array}$ & $\begin{array}{r}10.845 \\
>20\end{array}$ & $\begin{array}{r}11.928 \\
0.058\end{array}$ & $\begin{array}{r}-4.223 \\
>20 \\
37.391 \\
>20\end{array}$ & $\begin{array}{r}-11.736 \\
-0.014 \\
4.470 \\
>20\end{array}$ & $\begin{array}{rr}19.440 & \# \\
>20 & \\
-3.763 & \# \\
>20 & \# \\
22.347 & \# \\
>20 & \# \\
23.066 & \# \\
>20 & \#\end{array}$ \\
\hline S.D.N.Y. & & & & & & & $\begin{array}{l}2.311 \\
1.893 \\
-0.256 \\
-0.131\end{array}$ & & \\
\hline N.D. Ill. & & & \begin{tabular}{l|l|}
-2.540 \\
-2.871
\end{tabular} & & $\begin{array}{l}-1.325 \\
-1.043\end{array}$ & $\begin{array}{l}-7.392 \\
-0.062\end{array}$ & & & \\
\hline D. Mass. & & & & & & & $\begin{aligned} 42.191 & \# \\
>20 & \# \\
42.167 & \# \\
>20 & \end{aligned}$ & $\begin{array}{r}175.767 \\
>20 \\
174.044 \\
>20\end{array}$ & $\begin{array}{r}-22.873 \\
>20 \\
31.671 \\
0.119 \\
30.946 \\
0.117 \\
15.615 \\
0.022 \\
\end{array}$ \\
\hline D. Minn. & & & & $\begin{array}{l}2.302 \\
2.525\end{array}$ & $\begin{array}{r}21.796 \\
>20\end{array}$ & $\begin{array}{r}29.909 \\
>20\end{array}$ & \begin{tabular}{rr|}
-7.672 & $\#$ \\
$>20$ & \\
47.891 & $\#$ \\
$>20$ &
\end{tabular} & $\begin{array}{r}-91.448 \\
>20 \\
1.951 \\
2.132 \\
\end{array}$ & \\
\hline Other & & & & & $\begin{array}{l}0.441 \\
0.664\end{array}$ & $\begin{array}{l}1.760 \\
1.870\end{array}$ & $\begin{array}{l}1.650 \\
1.868 \\
3.018 \\
2.279\end{array}+$ & & \\
\hline SFCA per Judge & & & & & $\begin{array}{l}0.616 \\
1.771\end{array}$ & $\begin{array}{l}1.262 \\
2.555\end{array}$ & $\begin{array}{r}-0.277 \\
-0.657 \\
0.803 \\
1.703\end{array}$ & & \\
\hline Aggregate Docket & & & & & $\begin{array}{r}-0.094 \\
-1.511 \\
\end{array}$ & $\begin{array}{l}-0.273+ \\
-1.994 \\
\end{array}$ & & & \\
\hline Tech Intensity & $\begin{array}{l}8.121 \\
1.549 \\
\end{array}$ & & \begin{tabular}{ll|}
6.811 & $\#$ \\
3.480 & \\
\end{tabular} & & & & & & \\
\hline High Tech & $\begin{array}{l}-0.852 \\
-1.603\end{array}$ & $\begin{array}{l}-1.202+ \\
-2.340\end{array}$ & $\begin{array}{l}-0.712 \\
-1.781\end{array}$ & $\begin{array}{l}-0.622 \\
-1.525\end{array}$ & & & & $\begin{array}{l}-0.539 \\
-0.914 \\
-0.881 \\
-1.963 \\
\end{array}$ & \\
\hline
\end{tabular}


Table 14

(Continued)

Pleading Standard

Multivariate Forward Stepwise Regression Analysis

(All Observations)

\begin{tabular}{|c|c|c|c|c|c|c|c|c|c|}
\hline \multirow[b]{2}{*}{ Variable } & \multicolumn{6}{|c|}{ Dichotomous Regressions } & \multicolumn{3}{|c|}{ Polytomous Regressions } \\
\hline & Model 1 & Model 2 & Model 3 & Model 4 & Model 5 & Model 6 & Model 1 & Model 2 & Modal 3 \\
\hline Tech/Judge & & & & & & & & & \\
\hline Corp. & & & & & $\begin{array}{l}1.159 \\
1.699 \\
\end{array}$ & $\begin{array}{l}1.391 \\
1.345\end{array}$ & & & \\
\hline Prosec. & & $\begin{array}{l}0.859 \\
1.861\end{array}$ & $\begin{array}{l}0.805+ \\
2.152\end{array}$ & & & & $\begin{array}{r}1.455 \\
1.985 \\
0.153 \\
0.2059\end{array}$ & & \\
\hline MfultCase & $\begin{array}{l}0.719 \\
1.465\end{array}$ & & & $\begin{array}{l}-0.497 \\
-1.898\end{array}$ & $\begin{array}{l}0.002 \\
0.006\end{array}$ & $\begin{array}{l}-1.854+ \\
-2.035\end{array}$ & $\begin{array}{r}0.190 \\
0.647 \\
-1.512 \\
-1.849\end{array}$ & $\begin{array}{r}0.604 \\
2.286 \\
0.268 \\
-0.933\end{array}$ & $\begin{array}{r}0.778 \\
J .337 \\
1.203 \\
2.040 \\
-0.207 \\
-0.284 \\
0.525 \\
0.871\end{array}$ \\
\hline Observations & 167 & 167 & 167 & 167 & 101 & 101 & 101 & 167 & 167 \\
\hline $\begin{array}{l}\text { p-value for Model } \\
\text { Signifieance }\end{array}$ & 0.0 & 0.0 & 0.0 & 0.0 & 0.0 & 0.0 & 0.0 & 0.0 & 0.0 \\
\hline
\end{tabular}

- denotes statistical signifieance at the $1 \%$ confidence level

\# denotes statistical significance at the $0.1 \%$ confidence level

Table 15

Pleading Standard

Multivariate Forward Stepwise Regression Analysis (Individual Judge)

\begin{tabular}{|c|c|c|c|c|c|c|c|c|c|}
\hline \multirow[b]{2}{*}{ Variable } & \multicolumn{6}{|c|}{ Dichotomous Regressions } & \multicolumn{3}{|c|}{ Polytomous Regressions } \\
\hline & Model 1 & Model 2 & Madel 3 & Model 4 & Madel 5 & Model 6 & Model 1 & Model 2 & Model 3 \\
\hline Canter & & $\begin{array}{l}-9.564 \\
-0.130\end{array}$ & $\begin{array}{r}-11.624 \\
-0.198\end{array}$ & $\begin{array}{r}-12.234 \\
-0.083\end{array}$ & $\begin{array}{r}-10.682 \\
-0.11\end{array}$ & $\begin{array}{r}-20.305 \\
-0.202\end{array}$ & $\begin{array}{r}-54.650 \\
>20 \\
-29.455 \\
-720\end{array}$ & $\begin{array}{r}-32.462 \\
>20 \\
-25.268 \\
>20\end{array}$ & $\begin{array}{r}0.2361 \\
0.252 \\
-27.880 \\
>20 \\
-30.204 \\
>20 \\
-33.713 \\
>20\end{array}$ \\
\hline Nixon & & & $\begin{array}{l}-2.335 \\
-1.861\end{array}$ & & $\begin{array}{r}-12.836 \\
-0.043\end{array}$ & $\begin{array}{r}-20.120 \\
-0.21 S\end{array}$ & $\begin{array}{r}-25.848 \\
>20 \\
-27.645 \# \\
>20\end{array}$ & $\begin{array}{r}-23.501 \\
>20 \\
-2.056 \\
-1.577\end{array}$ & $\begin{array}{r}0.536 \\
0.446 \\
-36.569 \\
>20 \\
-36.935 \\
>20 \\
-1.075 \\
-0.681\end{array}$ \\
\hline Other & & $\begin{array}{l}-9.264 \\
-0.119\end{array}$ & & & $\begin{array}{l}1.716 \\
1.280\end{array}$ & & $\begin{array}{r}-17.239 \\
>20 \\
3.374 \\
1.855 \\
\end{array}$ & & \\
\hline Magistrate & $\begin{array}{l}-3.675 \\
-2.457\end{array}$ & & & & & $\underset{>20}{23.512}$ & & & \begin{tabular}{rr|}
-34.948 & $\#$ \\
$>20$ & \\
-36.287 & $\#$ \\
$>20$ & \\
-0.415 & \\
-0.362 & \\
-29.862 & $\#$ \\
$>20$ &
\end{tabular} \\
\hline
\end{tabular}


Table 15

(Continued)

Pleading Standard

Multivariate Forward Stepwise Regression Analysis

(Individual Judge)

\begin{tabular}{|c|c|c|c|c|c|c|c|c|c|}
\hline \multirow[b]{2}{*}{ Variable } & \multicolumn{6}{|c|}{ Dichotomous Regressions } & \multicolumn{3}{|c|}{ Polytomous Regressions } \\
\hline & Model 1 & Model 2 & Model 3 & Model 4 & Model 5 & Model 6 & Model 1 & Model 2 & Modal 3 \\
\hline N.D. Cal. & & & & $\begin{array}{l}3.182+ \\
2.668\end{array}$ & & & & & \\
\hline E.D. Pa. & & & & & $\begin{array}{l}-2.181 \\
-1.690\end{array}$ & & & & \\
\hline D. Mass. & & & $\begin{array}{r}12.842 \\
0.142\end{array}$ & . & $\begin{array}{r}11.792 \\
0.055\end{array}$ & $\begin{array}{r}-11.810 \\
-0.558\end{array}$ & $\begin{array}{r}35.784 \\
>20 \\
33.597 \\
>20\end{array}$ & $\begin{array}{r}25.044 \\
>20 \\
22.841 \\
>20\end{array}$ & \\
\hline S.D.N.Y. & $\begin{array}{l}-1.275 \\
-1.584\end{array}$ & & & & & & $\begin{array}{r}3.349 \\
2.114 \\
-0.782 \\
-0.386\end{array}$ & & \\
\hline N.D. Ill. & & & & & $\begin{array}{l}-1.704 \\
-1.471 \\
\end{array}$ & $\begin{array}{r}-17.699 \\
-0.19 \\
\end{array}$ & & & \\
\hline D. Minn. & & & $\begin{array}{l}6.916 \\
0.121\end{array}$ & $\begin{array}{r}12.052 \\
0.125\end{array}$ & $\begin{array}{r}12.623 \\
0.034\end{array}$ & $\begin{array}{r}27.472 \\
>20\end{array}$ & $\begin{array}{r}-7.735 \\
>20 \\
29.685 \\
>20\end{array}$ & $\begin{array}{r}-1.643 \\
>20 \\
18.750 \\
>20\end{array}$ & $\begin{array}{r}-14.710 \\
>20 \\
-11.325 \\
>20 \\
20.211 \\
>20 \\
19.166 \\
>20\end{array}$ \\
\hline C.D. Cal. & & & & & $\begin{array}{r}-12.685 \\
-0.045\end{array}$ & $\begin{array}{r}-17.062 \\
>20\end{array}$ & & & \\
\hline N.D. Tex. & & & & & & & $\begin{array}{r}40.815 \\
>20 \\
-20.093 \\
>20\end{array}$ & $\begin{array}{r}15.220 \\
>20 \\
-8.111 \\
>20\end{array}$ & \\
\hline SFCA per Judge & & & & & & & $\begin{array}{r}-0.454 \\
-0.912 \\
0.803 \\
1.967 \\
\end{array}$ & & \\
\hline Aggregate Docket & & & $\begin{array}{l}-0.212^{*} \\
-2.771\end{array}$ & & & & $\begin{array}{l}-0.207 \\
-1.971 \\
-0.313 \\
-2.495\end{array}+$ & $\begin{array}{c}-0.102 \\
-1.252 \\
10.156+ \\
1.361\end{array}$ & \\
\hline Docket per Judge & & & $\begin{array}{l}7.402 \\
2.980\end{array}$ & & & & $\begin{array}{l}8.370+ \\
2.598 \\
6.221 \\
\end{array}$ & $\begin{array}{l}6.527+ \\
2.379 \\
5.107+\end{array}$ & \\
\hline High Tech & & & $\begin{array}{l}-8.125 \\
-1.442 \\
\end{array}$ & & & $\begin{array}{r}21.876 \\
0.611 \\
\end{array}$ & & & \\
\hline Tech/Judge & & $\begin{array}{l}2.105 \quad \# \\
2.809\end{array}$ & $\begin{array}{l}7.271 \div \\
2.243\end{array}$ & & & & & $\begin{array}{r}0.730 \\
0.2870 \\
3.489 \\
2.731\end{array}$ & $\begin{array}{l}-0.411 \\
-0.195 \\
-2.843 \\
-0.769 \\
0.906 \\
0.392 \\
2.668 \\
1.269 \\
\end{array}$ \\
\hline Prosec. & & & $\begin{array}{l}0.937 \\
1.915\end{array}$ & & & & & $\begin{array}{l}1.337 \\
1.833 \\
0.711 \\
1.833 \\
\end{array}$ & \\
\hline Corp. & $\begin{array}{r}-2.507 \\
-1.672 \\
\end{array}$ & & & & & & & & \\
\hline MultCase & & $\begin{array}{l}-1.451 \\
-1.290\end{array}$ & & & & & & & \\
\hline
\end{tabular}


Table 15

(Continued)

Pleading Standard

Multivariate Forward Stepwise Regression Analysis

(Individual Judge)

\begin{tabular}{|c|c|c|c|c|c|c|c|c|c|}
\hline \multirow[b]{2}{*}{ Variable } & \multicolumn{6}{|c|}{ Dichotomous Regressions } & \multicolumn{3}{|c|}{ Polytomous Regressions } \\
\hline & Model 1 & Model 2 & Model 3 & Model 4 & Model 5 & Model 6 & Model 1 & Model 2 & Modal 3 \\
\hline RpiJdg. & $\begin{array}{l}2.241 \\
1.805\end{array}$ & & $\begin{array}{l}-1.182 \\
-2.012\end{array}+$ & $\begin{array}{l}-1.257 \\
-2.117\end{array}+$ & & $\begin{array}{l}-1.454 \\
-1.739\end{array}$ & $\begin{array}{l}-0.653 \\
-0.803 \\
-2.301 \\
-2.155\end{array}+$ & $\begin{array}{l}-0.579 \\
-0.761 \\
-1.588 \\
-2.277\end{array}+$ & $\begin{array}{l}2.356 \\
1.901 \\
2.314 \\
1.800 \\
0.918 \\
0.716 \\
0.565 \\
0.416\end{array}$ \\
\hline Observations & 116 & 116 & 116 & 116 & 78 & 78 & 78 & 116 & 116 \\
\hline $\begin{array}{c}\text { p-value for Model } \\
\text { Significance }\end{array}$ & 0.0 & 0.0 & 0.0 & 0.0 & 0.0 & $\overline{0.0}$ & 0.0 & 0.0 & 0.0 \\
\hline Votes: See Table 1 & & & & & & & & & \\
\hline
\end{tabular}

2. Outcome regressions.

Tables 16,17 , and 18 report the results of multivariate forward stepwise regressions that search for the set of explanatory variables that is most significantly correlated with the resolution of the underlying motions to dismiss. 
Table 16

Ruling on Motion to Dismiss

Multivariate Forward Stepwise Regressions

Pleading Variable Omitted

(All Observations)

\begin{tabular}{|c|c|c|c|c|c|c|c|}
\hline \multirow{2}{*}{ Variable } & \multicolumn{4}{|c|}{ Dichotomous Regressions } & \multicolumn{3}{|c|}{ Polytomous Regressions } \\
\hline & Model 1 & Model 2 & Model 3 & Model 4 & Model 1 & Model 2 & Modal 3 \\
\hline Clinton & & & & & & $\begin{array}{r}0.985 \\
1.265 \\
-0.529 \\
-1.132\end{array}$ & \\
\hline Bush & $\begin{array}{l}0.858 \\
1.551\end{array}$ & & & & $\begin{array}{l}1.342 \\
2.333 \\
0.283 \\
0.408\end{array}$ & & $\begin{array}{c}1.371 \\
2.393 \\
0.155 \\
0.131 \\
-12.977 \quad \# \\
>20 \\
0.745 \\
1.008 \\
\end{array}$ \\
\hline Reagan & & & & $\begin{array}{r}0.8741 \\
1.988\end{array}$ & & & \\
\hline Ford & & & $\begin{array}{l}7.702 \\
0.253\end{array}$ & $\begin{array}{l}11.626 \\
-0.115\end{array}$ & & \begin{tabular}{cc|}
-0.762 & $\#$ \\
$>20$ & \\
14.732 & $\#$ \\
$>20$ &
\end{tabular} & \\
\hline Magistrate & & & $\begin{array}{l}-7.2933 \\
-0.300\end{array}$ & $\begin{array}{l}-9.743 \\
-0.122\end{array}$ & & $\begin{array}{l}-11.444 \\
-0.298 \\
-13.127 \\
-0.030\end{array}$ & \\
\hline S.D.N.Y. & & & $\begin{array}{l}-1.035 \\
-1.736\end{array}$ & & $\begin{array}{r}0.875 \\
1.628 \\
-0.479 \\
-0.700\end{array}$ & & \\
\hline N.D. Cal. & $\begin{array}{l}1.987 \\
1.879\end{array}$ & & & & $\begin{array}{l}2.254+ \\
2.044 \\
1.980 \\
I .808\end{array}$ & & \\
\hline N.D. Ill. & $\begin{array}{l}-0.988 \\
-I .488\end{array}$ & $\begin{array}{l}-9.900 \\
-0.161\end{array}$ & $\begin{array}{c}-1.537 \\
-1.421\end{array}$ & $\begin{array}{l}-10.667 \\
-0.1146\end{array}$ & , & $\begin{array}{r}-0.188 \\
0.132 \\
-14.280 \\
>20\end{array}$ & \\
\hline SFCAJudge & & & & & & $\begin{array}{l}-0.709 \\
-1.511 \\
-0.662 \\
-2.314\end{array}+$ & $\begin{array}{c}0.390+ \\
2.433 \\
-0.627 \\
-1.499 \\
0.301 \\
1.005 \\
0.382+ \\
2.148 \\
\end{array}$ \\
\hline Tech Intensity & & & & $\begin{array}{l}1.503 \\
1.771\end{array}$ & & & \\
\hline Tech/Judge & & $\begin{array}{l}1.106+ \\
2.392\end{array}$ & & & & $\begin{array}{r}-3.091 \\
-0.667 \\
2.963 \\
2.657\end{array}$ & \\
\hline Docket & & & & & & & $\begin{array}{c}-0.020 \\
-0.0204 \\
0.092 \\
1.209 \\
-0.422+ \\
-2.188 \\
-0.053 \\
-0.863\end{array}$ \\
\hline $\begin{array}{c}\text { Docket per } \\
\text { Judge }\end{array}$ & & & & $\begin{array}{l}-3.264 \\
-1.640 \\
\end{array}$ & & & \\
\hline Judge & & & & $\begin{array}{l}-0.696 \\
-1.550\end{array}$ & & & \\
\hline MultCase & & & & $\begin{array}{l}-0.449 \\
-1.686\end{array}$ & & & \\
\hline RptJdg. & 0.680 & & $\frac{1.110}{2.964}$ & $\begin{array}{l}1.866 \# \\
3.440\end{array}$ & $\begin{array}{l}0.236 \\
0.576 \\
1.195 \\
2.764\end{array}$ & $\begin{array}{l}0.818 \\
1.053 \\
1.355 \\
2.553\end{array}$ & $\begin{array}{l}0.190 \\
0.456 \\
0.859 \\
1.109 \\
2.966+\end{array}$ \\
\hline & & & & & & & $\begin{array}{l}2.321 \\
0.938 \\
1.829\end{array}$ \\
\hline Observations & 167 & 167 & 167 & 167 & 167 & 167 & 167 \\
\hline $\begin{array}{l}\text { P-value for } \\
\text { Model } \\
\text { Significance }\end{array}$ & 0.0 & 0.0 & 0.0 & 0.0 & 0.0 & 0.0 & 0.0 \\
\hline
\end{tabular}


Table 16 reports the results of regressions run on the All Observations sample that do not include any variable that describes the pleading standard selected by the court in that case. The only variable that is significant in more than two regression models reported in Table 16 is RptJdg, a binary variable that measures whether a judge has more than one decision in our database. The coefficient on that variable is positive in five of the six regressions, indicating that judges with more than one observation in the sample tend to rule in a more pro-defendant manner.

The failure to include an explanatory variable that measures the pleading standard selected by the court is potentially problematic. In particular, if the underlying structural model is that the courts first select an interpretive standard and then apply that standard in a consistent manner to the resolution of the underlying motion to dismiss, then the exclusion of such an explanatory variable generates an omitted-variable problem and the underlying model would fail accurately to describe the underlying decision making process.

To test for this possibility we incorporate the independent variable "Pleading," previously defined for inclusion in Tables 12 and 13 . If the pleading standard selected by the court has a statistically significant influence on the resolution of the underlying motion, then the coefficient on the Pleading variable should be positive and significant. Tables 17 and 18 address this question from two perspectives. Table 17 reports regression results for the All Observations sample with the Pleading variable included among the explanatory variables. These results must, however, be interpreted with caution because the Pleading variable is defined in a manner that already incorporates information about the resolution of the motion. Specifically, to the extent that a court adopts a minimalist approach and either dismisses or grants the motions without articulating an interpretive standard, the resort to a minimalist standard is already correlated with a pro-plaintiff or pro-defendant outcome. Put another way, as long as minimalist decisions are included in the dataset, the Pleading variable is not truly an independent explanatory variable. With these significant caveats in mind, Table 17 documents a positive, robust, statistically significant correlation with the pleading standard and with the fact that a judge has more than one observation in the sample.

Table 18 reports the results of regressions run over a constrained dataset that excludes from analysis all decisions in which judges adopt minimalist styles. It therefore reports a more valid test of the hypothesis that the selection of an interpretive standard influences the resolution of the motion. The results reported in Table 18 suggest that only the RptJdg variable is statistically significant in more than two specifications of the model. The coefficients on that variable are consistently positive, again suggesting a more pro-defendant inclination from judges who decide more than one case in our sample. The 
pleading standard is statistically significant in only two specifications, both polytomous, and in both cases with the expected positive coefficients indicating that the stronger the pleading standard the more likely the result will favor the defendants.

Table 17

Ruling on Motion to Dismiss

Multivariate Forward Stepwise Regressions

Pleading Variable Included

(All Observations)

\begin{tabular}{|c|c|c|c|c|c|c|c|}
\hline \multirow[b]{2}{*}{ Variable } & \multicolumn{4}{|c|}{ Dichotomous Regressions } & \multicolumn{3}{|c|}{ Polytomous Regressions } \\
\hline & Model 1 & Model 2 & Model 3 & Model4 & Model I & Model 2 & Model 3 \\
\hline Clinton & & & & & & $\begin{array}{r}0.930 \\
1.164 \\
-0.627 \\
-1.360\end{array}$ & \\
\hline Bush & $\begin{array}{l}1.432+ \\
2.052\end{array}$ & & & & $\begin{array}{l}1.830+ \\
2.580 \\
0.652 \\
0.787\end{array}$ & & $\begin{array}{c}1.505+ \\
2.233 \\
0.281 \\
0.226 \\
-12.550 \\
>20 \\
0.691 \\
-0.795\end{array}$ \\
\hline Reagan & & & $\begin{array}{l}0.608 \\
1.577\end{array}$ & $\begin{array}{l}0.776 \\
1.791 \\
\end{array}$ & & & \\
\hline Carter & $\begin{array}{l}1.776 \\
2.077\end{array}$ & & & & $\begin{array}{l}+.010 \\
2.243 \\
1.390 \\
1.300\end{array}$ & & \\
\hline Ford & & & $\begin{array}{l}9.091 \\
0.185\end{array}$ & $\begin{array}{c}11.962 \\
0.079\end{array}$ & & $\begin{array}{r}0.549 \\
-0.124 \\
11.202 \\
0.086 \\
\end{array}$ & \\
\hline Magistrate & & & & $\begin{array}{r}-11.322 \\
-0.049\end{array}$ & & & \\
\hline S.D.N.Y. & & & & & $\begin{array}{r}1.070 \\
1.774 \\
-0.327 \\
-0.439\end{array}$ & & \\
\hline N.D. Ill. & & $\begin{array}{r}-7.219 \\
-0.253\end{array}$ & & $\begin{array}{r}-11.654 \\
-0.061\end{array}$ & & & \\
\hline $\begin{array}{l}\text { SFCA per } \\
\text { Judge }\end{array}$ & & & & & & $\begin{array}{l}-0.817+ \\
-2.072 \\
-0.041 \\
-0.311\end{array}$ & \\
\hline $\begin{array}{l}\text { SFCA } \\
\text { Docket }\end{array}$ & & & & & & & $\begin{array}{r}0.010 \\
1.726 \\
-0.028 \\
-1.363 \\
0.023 \\
1.129 \\
0.015 \\
1.1 S 1 \\
\end{array}$ \\
\hline
\end{tabular}




\section{Table 17}

(Continued)

Ruling on Motion to Dismiss

Multivariate Forward Stepwise Regressions

Pleading Variable Included

(All Observations)

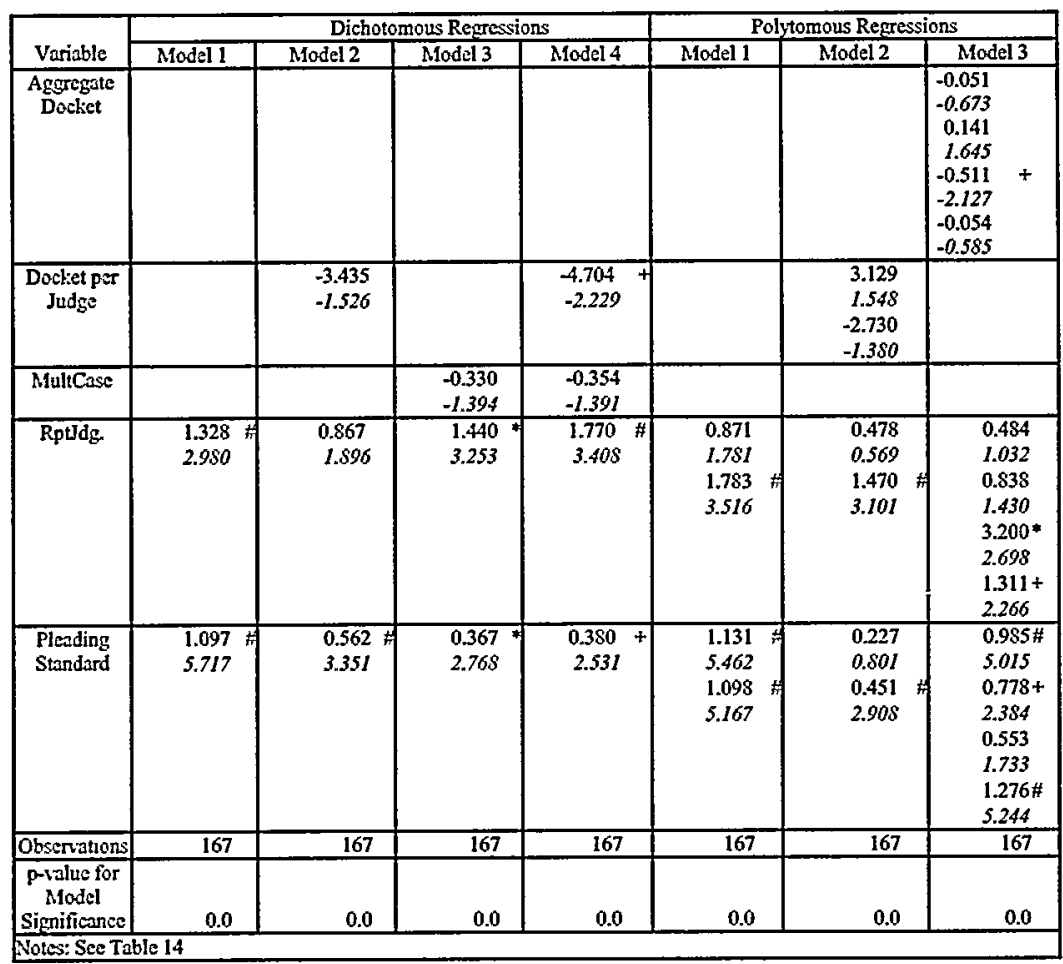


Table 18

Ruling on Motion to Dismiss

Multivariate Forward Stepwise Regressions

Pleading Variable Included

(Excluding Minimalist Holdings)

\begin{tabular}{|c|c|c|c|c|c|c|c|}
\hline \multirow{2}{*}{ Variable } & \multicolumn{4}{|c|}{ Dichotomous Regressions } & \multicolumn{3}{|c|}{ Polytomous Regressions } \\
\hline & Model 1 & Model 2 & Model 3 & Model 4 & Model I & Model 2 & Model 3 \\
\hline Bush & & & & & $\begin{array}{l}1.621 \\
2.093 \\
0.200 \\
0.212\end{array}$ & & $\begin{array}{r}1.953 \\
2.473 \\
-27.999 \\
>20 \\
-18.496 \\
>20 \\
1.276 \\
1.240\end{array}$ \\
\hline Carter & & & & & $\begin{array}{l}2.219 \\
2.308 \\
0.914 \\
0.636\end{array}$ & & $\begin{array}{r}2.319 \\
2.419 \\
-22.265 \\
>20 \\
3.440 \\
1.945 \\
-11.675 \\
>20 \\
\end{array}$ \\
\hline N.D. Ill. & & & & & $\begin{array}{r}-0.547 \\
-0.575 \\
-15.848 \\
>20\end{array}$ & & \\
\hline S.D.N.Y. & & & $\begin{array}{r}-2.028+ \\
3.492\end{array}$ & & & & \\
\hline Docket per Judge & & & & & & $\begin{array}{r}5.488 \\
1.993 \\
-2.436 \\
-1.037\end{array}$ & \\
\hline ABA Rank & & & & & $\begin{array}{l}1.140 \\
1.922 \\
0.447 \\
0.714\end{array}$ & & \\
\hline Public Int. & & & & & $\begin{array}{r}-2.367 \\
-1.827 \\
1.695 \\
0.725\end{array}$ & & \\
\hline MultCase & & & & & $\begin{array}{l}2.967 \\
1.884 \\
1.696 \\
1.103\end{array}$ & & \\
\hline RptJdg. & & & $\begin{array}{l}1.293 \\
7.163\end{array}$ & & $\begin{array}{l}1.084 \\
1.267 \\
2.009 \\
2.502\end{array}+$ & $\begin{array}{r}-0.914 \\
-0.69 I \\
1.797 \\
3.230\end{array}$ & $\begin{array}{l}1.704 \\
2.507 \\
0.273 \\
0.224 \\
4.277 \\
3.073 \\
2.514 \\
3.064\end{array}$ \\
\hline Pleading Standard & & & & & & $\begin{array}{r}-0.199 \\
-0.495 \\
0.623 \\
2.994\end{array}$ & $\begin{array}{l}1.207 \\
4.498 \\
0.305 \\
0.707 \\
1.099 \\
2.193 \\
1.633 \\
4.688 \\
\end{array}$ \\
\hline Observations & 101 & 101 & 101 & 101 & 101 & 101 & 101 \\
\hline \begin{tabular}{|c|} 
p-value for Model \\
Significance
\end{tabular} & 0.0 & 0.0 & 0.0 & 0.0 & 0.0 & 0.0 & 0.0 \\
\hline Notes: See Table 14 & & & & & & & \\
\hline
\end{tabular}




\section{Discussion of Multivariate Results}

We suggest that this statistical analysis of the district court data counsels caution more powerfully than it supports any sweeping assertions about patterns in the behavior of district court judges. As is apparent from the univariate and multivariate analyses alike, the significance of individual explanatory variables is highly contingent on the specification of the dependent variable and the regression technique employed. Because there is no generally accepted theory that argues for the superiority of any one model over the others, any emphasis on regressions that tend to display statistically significant relationships can reflect data mining rather than analytically meaningful and robust statistical relationships.

With this very significant caution firmly in mind, we call attention to a small number of patterns that are apparent in the data, while simultaneously urging readers not to overinterpret these findings. In particular, the multivariate data suggest that the more often a judge rules on cases in our sample, the more likely the judge will issue pro-defendant rulings. This tendency supports the observation that "familiarity breeds skepticism" when it comes to resolving motions to dismiss. The data are not, however, as strong in supporting the conclusion that the selection of a pleading standard is statistically significant in determining the outcome of the litigation. Thus, consistent with our analysis of the appellate court data, there appears to be significant plasticity in the application of standards to facts, but there is a tendency for more stringent interpretations of the pleading standard to be correlated with pro-defendant outcomes.

When it comes to explaining the selection of the interpretive standard it seems that judges with more senior status, having been appointed by Presidents Carter, Ford, or Nixon, tend to adopt more pro-plaintiff interpretations. The pro-defendant Northern District of California effect appears to be present only in the All Observations sample because a large number of the most prodefendant decisions in that district were generated by a small number of judges.

Focusing on the Individual Judge sample, however, suggests that judges who have busier dockets and who serve in districts with more technology cases per judge tend to adopt pro-defendant interpretations. We thus suggest that the popular perception that the Northern District of California tends to be prodefendant in interpreting the "strong inference" standard is actually a reflection of the fact that the Northern District tends to have a large technology docket and a busy civil docket, rather than a reflection on the inclinations of the individual judges who sit on that bench.

The fact that the RptJdg variable is statistically significant and negative we believe reflects an interaction effect with the Tech/Judge and Docket per Judge variables. Thus, rather than refuting the "familiarity breeds skepticism" conclusion suggested by the univariate analysis, the RptJdg variable, which 
would also capture a Northern District of California effect because of the disproportionate presence of "repeat judges" in that district, acts to moderate the effects of the Tech/Judge and Docket per Judge variables.

If this interpretation is correct, it suggests that judges in districts that have a large number of technology cases per judge, and with a large docket load per judge, tend to adopt pro-defendant interpretations of the standard. These findings are consistent with the "technology is different" and "docket control" hypotheses suggested earlier in the analysis.

These multivariate results also suggest that many variables that appeared to be significant in the univariate analysis do not retain their significance in multivariate regression. While this result is hardly surprising from a statistical perspective, it is valuable to underscore here because much of the "common wisdom" about judicial tendencies in the area of securities fraud litigation is driven by impressions that are, at best, consistent with a subjective univariate impression of the data. As the preceding analysis suggests, those impressions are probably deceptive. 